UNIVERSIDADE DE BRASÍLIA

FACULDADE DE AGRONOMIA E MEDICINA VETERINÁRIA - FAV

PROGRAMA DE PÓS-GRADUAÇÃO EM AGRONOMIA

FATORES EDÁFICOS DE LATOSSOLOS FÉRRICOS NA PRODUTIVIDADE DE CANA-DE-AÇÚCAR NA REGIÃO SUL DE GOIÁS

ALCEU LINARES PÁDUA JUNIOR

TESE DE DOUTORADO EM AGRONOMIA 
UNIVERSIDADE DE BRASÍLIA - UNB

FACULDADE DE AGRONOMIA E MEDICINA VETERINÁRIA - FAV

PROGRAMA DE PÓS-GRADUAÇÃO EM AGRONOMIA

FATORES EDÁFICOS DE LATOSSOLOS FÉRRICOS NA PRODUTIVIDADE DE CANA-DE-AÇÚCAR NA REGIÃO SUL DE GOIÁS

ALCEU LINARES PÁDUA JUNIOR

ORIENTADORA: MARILUSA PINTO COELHO LACERDA

CO-ORIENTADOR: THOMAZ ADOLPHO REIN

TESE DE DOUTORADO EM AGRONOMIA

PUBLICAÇÃO: 046D/2016 


\title{
FATORES EDÁFICOS DE LATOSSOLOS FÉRRICOS NA PRODUTIVIDADE DE CANA-DE-AÇÚCAR NA REGIÃO SUL DE GOIÁS
}

\author{
ALCEU LINARES PÁDUA JUNIOR \\ Matrícula: 120046865
}

TESE DE DOUTORADO SUBMETIDO AO PROGRAMA DE PÓS-GRADUAÇÃo EM AGRONOMIA, COMO PARTE DOS REQUISITOS NECESSÁRIOS À OBTENÇÃO DO GRAU DE DOUTOR EM AGRONOMIA.

APROVADA POR:

Dra. Marilusa Pinto Coelho Lacerda, Professora UnB/FAV Orientadora CPF: 434.760.586-20/marilusa@unb.br

Dr. Sebastião Alberto de Oliveira, Professor UnB/FAV Membro interno - CPF: 052.361.771-20/ saoliveira1945@gmail.com

Dr. Marcelo Fagioli, Professor UnB/FAV Membro interno - CPF: 729.409.306-78/ mfagioli@unb.br

Dr. Vinicius Bof Bufon, Pesquisador - Embrapa Cerrados - Membro externo CPF: 073.388.357-56/ vinicius.bufon@embrapa.br

Dr. Marcos Aurélio Carolino de Sá, Pesquisador - Embrapa Cerrados - Membro externo - CPF:157.404.258-08/ carolino@ cpac.embrapa.br

BRASÍLIA/DF, 31 de maio de 2016. 


\section{FICHA CATALOGRÁFICA}

Pádua Junior, Alceu Linares.

Fatores edáficos Latossolos férricos na produtividade de cana-deaçúcar na região Sul de Goiás / Alceu Linares Pádua Junior; orientadora Marilusa Pinto Coelho Lacerda; co-orientador Thomaz Adolpho Rein. Brasília, 2016.

118p. : il.

Tese de Doutorado (D) - Universidade de Brasília/Faculdade de Agronomia e Medicina Veterinária, 2016.

1. Horizonte concrecionário. 2. Ácrico. 3. Distrófico. 4. Potencial hídrico foliar.

I. Lacerda, M.P.C. II. Pós Doutora.

III. Rein, T.A. IV. Doutor

\section{REFERÊNCIA BIBLIOGRÁFICA}

PÁDUA JUNIOR, A. L. Fatores edáficos Latossolos férricos na produtividade de cana-

de-açúcar na região Sul de Goiás. Brasília: Faculdade de Agronomia e Medicina Veterinária, Universidade de Brasília, 2016, 118p. Tese de Doutorado.

\section{CESSÃO DE DIREITOS}

NOME DO AUTOR: Alceu Linares Pádua Junior

TÍTULO DA TESE DE DOUTORADO: Fatores edáficos Latossolos férricos na produtividade de cana-de-açúcar na região Sul de Goiás

GRAU: DOUTOR ANO: 2016

É concedida à Universidade de Brasília de Brasília permissão para reproduzir cópias desta dissertação de mestrado para única e exclusivamente propósitos acadêmicos e científicos. $\mathrm{O}$ autor reserva para si os outros direitos autorais, de publicação. Nenhuma parte desta dissertação de mestrado pode ser reproduzida sem a autorização por escrito do autor. Citações são estimuladas, desde que citada à fonte.

Alceu Linares Pádua Junior

CPF: 213.692.538-50

Endereço: Avenida Castro Alves, 442, Bairro Divineia, Unaí-MG, CEP: 38610-000

Tel: (38) 99131-9285

Email: alceulinares@ hotmail.com/alceulinaresjrr@gmail.com 
Dedico aos meus pais Alceu Linares Pádua e Enedir Carmen Moura Linares, pelo carinho, esforço e sacrifício no custeio do meu curso de graduação e por mostrarem como agir diante das situações que a vida me apresentou, obrigado por me ajudarem a fazer as escolhas corretas. À minha irmã Elisângela Moura Linares, que apesar de distante fisicamente sempre esteve ao meu lado, seja em orações ou virtualmente. À minha esposa Marcionília Soares Amaral, por estar forte e ao meu lado durante todo os momentos de sacrifício e dificuldades vividos nestes quatro anos, obrigado por dar os presentes mais importantes de minha vida, nossa filha e por me fazer descobrir o amor. Você é a razão de eu estar aqui hoje! Você é toda minha razão! Obrigado! À minha princesinha Letícia Amaral Linares, só a razão de você existir vale todo o esforço e luta que percorri até este momento, força, superação e capacidade de nunca desistir eu aprendi com você. Dedico. 


\section{AGRADECIMENTOS}

A Deus, por estar ao meu lado e me dar forças para enfrentar esta importante etapa em minha vida.

À minha família que esteve sempre comigo nos bons e maus momentos me dando força e incentivando para a conclusão e obtenção do título de Doutor.

À minha orientadora, professora Dra. Marilusa Pinto Coelho Lacerda pela amizade, atenção, confiança e profissionalismo, além do vasto conhecimento, que contribuíram para a produção desta obra, serei eternamente grato a você.

Ao meu co-orientador Dr. Thomaz Adolpho Rein, pela amizade, pelo exemplo profissional, caráter e conhecimentos compartilhados durante o desenvolvimento do trabalho.

Ao Manuel Pereira Júnior, pela incondicional amizade e ajuda. Considero- te como o irmão que não tive.

Ao Dr. Marcos Carolino Aurélio Sá, pela receptividade, amizade e por me ajudar na elaboração e interpretação das características físicas dos solos.

Ao Dr. João de Deus Gomes dos Santos Júnior, pela amizade, e conhecimentos compartilhados nas visitas à usina. Nunca vou esquecer as muitas vezes que você ligou a música "Hálito de Champagne" nas madrugadas de avaliação de potencial hídrico foliar na cana-de-açúcar.

Ao Dr. Juaci Vitória Malaquias, pelo conhecimento e auxílio na elaboração das análises estatísticas.

Ao Dr. Marcelo Mencarini Lima pela amizade e pelas palavras de incentivo e motivação.

Aos Drs. Sebastião Alberto de Oliveira, Marcelo Fagioli, Vinicius Bof Bufon e Thais Rodrigues Coser por contribuírem com seus conhecimentos e avaliação desta tese.

À EMPRESA BRASILEIRA DE PESQUISA AGROPECUÁRIA - EMBRAPA, pelo auxílio financeiro e por disponibilizar os laboratório de Física e Química dos Solos, para determinação das análises. 
Aos funcionários do laboratório de Física dos Solos da EMBRAPA/CPAC Nelson Camargos Moreira e Lucas Cardoso da Silva, pela conhecimento e amizade.

Aos grandes profissionais do campo, Jesuíno de Sousa Caldas, Edson Douglas de Oliveira e José Carlos Pereira Barbosa, pela amizade e experiência no auxílio na coleta de amostras no campo.

À Usina Goiasa, por disponibilizar suas dependências físicas para elaboração do experimento e pelos técnicos de campo sempre disponíveis para amostragens no campo.

Ao técnico da usina Goiasa, Joaquim Fonseca de Souza, pela amizade, e por estar sempre prestativo no que era solicitado para a realização da pesquisa.

À professora Janua Celi de Miranda pela amizade e incentivo e conhecimento que foram importantes para a realização deste trabalho.

Aos funcionários, colegas e alunos da Faculdade de Ciências e Tecnologia de Unaí pela amizade e confiança em meu trabalho na instituição.

Aos colegas, funcionários e professores do Programa de Pós-Graduação em Agronomia da FAVUnB.

E a todas as pessoas que de alguma forma contribuíram para a realização deste trabalho. 


\title{
FATORES EDÁFICOS DE LATOSSOLOS FÉRRICOS NA PRODUTIVIDADE DE CANA-DE-AÇÚCAR NA REGIÃO SUL DE GOIÁS
}

\author{
RESUMO GERAL
}

Por ser uma cultura que explora o perfil do solo em profundidade a cana-de-açúcar pode expressar seu potencial produtivo em função das propriedades químicas e características morfológicas e físico-hídricas dos solos. O objetivo do trabalho foi compreender as características e propriedades do solo e que possam explicar a produtividade da cana-deaçúcar na região sul do Estado de Goiás. Para isso, foi analisado o banco de dados da Usina Goiasa, localizada no município de Goiatuba, com o propósito de criar um modelo preditivo para a produtividade da cana-de-açúcar em função das variáveis sistema de cultivo (orgânico e convencional), classes de solos (Latossolos Vermelhos Distroférricos (LVdf.1.1 e LVdf.1.4) e Latossolo Vermelho Acriférrico (LVwf.1.4)), precipitação pluviométrica, épocas de colheita no período de quatro cortes. Entretanto, o modelo geral indicou apenas o efeito dos cortes na produtividade da cultura de maneira decrescente do primeiro para o quarto corte. Ao mesmo tempo foi avaliado em dois pares de solos da Usina Goiasa (P1 - LVwf petroplíntico: Latossolo Vermelho Acriférrico petroplíntico P2 e P3 - LVwf: Latossolo Vermelho Acriférrico típico e P4 - LVdf: Latossolo Vermelho Distroférrico típico) a contribuição da morfologia, propriedades químicas e características físico-hídricas dos solos no potencial hídrico foliar da cultura e na produtividade da cana-de-açúcar, RB867515, nos anos de 2014 e 2015. No ano de 2014 a média de precipitação pluviométrica no mês de julho foi superior a $78 \mathrm{~mm}$, e contribuiu para diferença de produtividade entre as áreas P1 e P2. A avaliação da produtividade de cana-de-açúcar no período de corte de agosto de 2014 foi $33 \mathrm{Mg} \mathrm{ha}^{-1}$ superior no LVwf petroplíntico quando comparado ao LVwf típico, sem a presença de horizonte concrecionário. As análises de potencial hídrico foliar no mês de agosto de 2014 indicaram o menor estresse hídrico na RB867515 em Latossolo com horizonte concrecionário em profundidade. No par LVwf e LVdf a produtividade da cultura se diferenciou menos no ano de 2014. Provavelmente, a similaridade das características físicas dos solos possa responder a baixa variação de produtividade no par P3 e P4. No ano de 2015 a precipitação no mês de julho foi inferior ao ano anterior e a produtividade da cana-de-açúcar praticamente não diferiu entre os dois pares de solos. As análise de densidade do solo, volume total de poros e tamanhos de poros, indicaram compactação na superfície nos dois pares de solos. Porém, as curvas de retenção de água não indicaram diferença entre os pares de solos estudados. As análises de potencial hídrico foliar demonstraram o maior teor de água na cultura da cana-deaçúcar no ano de 2014 decorrentes do maior índice pluviométrico no mês de julho, principalmente no LVwf petroplíntico provavelmente pelo maior acúmulo de água em profundidade. No ano seguinte o potencial hídrico foliar foi maior no solo P1 (LVwf petroplíntico), porém, os valores não deferiram-se estatisticamente. Portanto, a oscilação do nível do lençol freático imposto pela presença do horizonte concrecionário associadas as análise de potencial hídrico na cultura da cana-de-açúcar foram importantes no diagnóstico da produtividade da cultura em anos climáticos atípicos.

Palavras-chave: saccharum spp. L., horizonte concrecionário, ácrico, distrófico, potencial hídrico foliar. 


\title{
FACTORS OF EDAPHIC FERRIC OXISOLS IN PRODUCTIVITY OF CANE SUGAR IN THE REGION SOUTH GOIÁS
}

\author{
GENERAL ABSTRACT
}

As a culture that explores the soil profile in depth, the sugarcane can express its productive potential in terms of chemical properties and morphological and physical-hydric characteristics of the soils. This study aim was to understand the characteristics and properties of the soil that may explain the productivity of sugarcane in the southern of Goiás state. For this, it was analyzed the database of Usina Goiasa, located in the city of Goiatuba, with the purpose of creating a predictive model for the sugarcane productivity in function of the variables: cultivation system (organic and conventional), soils classes (LVdf1.1, LVdf1.4 and LVwf), rainfall, harvest times in a four-cut period. However, the general model indicated only the effect of the cuts in the culture productivity in a decreasing way from the first to the fourth cut. At the same time, it was evaluated two pairs of soils of Usina (P1 - LVwf petroplinthic, P2 and P3 - LVwf typical, P4 - LVdf typical) the contribution of morphology, chemical properties and physical-hydric characteristics of the soils in the leaf water potential of the culture and in the productivity of the RB867515 sugarcane in the years of 2014 and 2015. In the year of 2014, the average rainfall in July was over $78 \mathrm{~mm}$, and contributed to the difference of productivity between $\mathrm{P} 1$ and $\mathrm{P} 2$ areas. The evaluation of sugarcane productivity in the cut-off period of August of 2014 was $33 \mathrm{Mg} \mathrm{ha}^{-1}$ higher in petroplinthic LVwf when compared to typical LVwf, without the presence of concretionary horizon. The leaf water potential analysis in August of 2014 showed the least water stress in RB867515 in Latosol with concretionary horizon in depth. In the pair LVwf x LVdf, the culture productivity differed less in 2014. Probably, the similarity of the physical characteristics of the soils may respond to low productivity variation in the pair P3 and P4. In the year 2015, the rainfall in July was lower than the previous year and the sugarcane productivity practically had no difference between the two pairs of soils. The analysis of soils density, total pore volume and pore sizes indicated compaction on the surface in the two pairs of soils. Yet, the water retention curves indicated no difference between the studied pairs of soils. The leaf water potential analysis demonstrated the highest water content in the sugarcane culture in 2014 resulting from the higher rainfall in July, mainly in LVwf petroplinthic, probably because of the larger accumulation of water in depth. In the following year, the leaf water potential was higher in the P1 soil (LVwf petroplinthic), nevertheless the values had no difference statistically. Therefore, the level oscillation of the water table imposed by the presence of the concretionary horizon associated to the analysis of the water potential in the sugarcane culture were significant in the diagnosis of the culture productivity in atypical weather years.

Key words: saccharum ssp. L., concretionary horizon, acric, dystrophic, leaf water potential. 


\section{LISTA DE ILUSTRAÇÕES}

\section{I - CAPÍTULO GERAL}

Figura 1. Aspectos de amarelecimento da cana-de-açúcar em Latossolo Vermelho Ácrico.

Figura 2. Variedade RB867515 cultivadas em Latossolo Vermelho Distroférrico sob sistema de irrigação por gotejamento 26

Figura 3. Desenvolvimento da variedade RB867515 em Latossolo Vermelho Distroférrico (a) Latossolo Vermelho Acriférrico (b) ambos no terceiro ciclo vegetativo no estado do Maranhão. 28

\section{II- CAPÍTULO I}

Figura 4. Localização dos municípios de Goiatuba e Bom Jesus no sul do estado de Goiás..47

\section{III - CAPÍTULO II}

Figura 5. Localização dos pontos dos solos estudados na Usina Goiasa, Goiatuba, GO....... 78

Figura 6. Densidade do solo (Ds) dos perfis de solos estudados P1 e P2 (A) e P3 e P4 (B) na Usina Goiasa, Goiatuba, GO - barras correspondem ao erro pleo teste t a $5 \%$ de probabilidade 88

Figura 7. Volume total de poros (VTP) dos perfis de solos estudados P1 e P2 (A) e P3 e P4 (B) na Usina Goiasa, Goiatuba, GO - barras correspondem ao erro pleo teste t a $5 \%$ de probabilidade. 90

Figura 8. Valores de macroporos (> $100 \mu \mathrm{m}$ ) dos perfis de solos estudados P1 e P2 (A) e P3 e P4 (B) na Usina Goiasa, Goiatuba, GO - barras correspondem ao erro pleo teste t a 5\% de probabilidade 91

Figura 9. Valores de mesoporos $(\leq 100 \mu \mathrm{m}$ a $\geq 30 \mu \mathrm{m})$ dos perfis de solos estudados P1 e P2 (A) e P3 e P4 (B) na Usina Goiasa, Goiatuba, GO - barras correspondem ao erro pleo teste $\mathrm{t}$ a $5 \%$ de probabilidade 92

Figura 10. Valores de microporos $(<30 \mu \mathrm{m})$ dos perfis de solos estudados P1 e P2 (A) e P3 e P4 (B) na Usina Goiasa, Goiatuba, GO - barras correspondem ao erro pleo teste t a $5 \%$ de probabilidade 93 


\section{LISTA DE TABELAS}

\section{II - CAPÍTULO I}

Tabela 1. Classe de solos em sistemas de cultivo de cana-de-açucar da Usina Goiasa, Goiatuba, GO 48

Tabela 2. Média da produtividade da cana-de-açúcar $\left(\mathrm{Mg} \mathrm{ha}^{-1}\right)$ por época de colheita e corte em sistema convencional e orgânico em diferentes classes de solos na Usina Goiasa, Goiatuba, GO 52

Tabela 3. Correlação Pearson entre as variáveis produtividade de cana-de-açúcar (TCH), precipitação pluviométrica acumulada dutante o ciclo da cultura e data do corte nos sistemas de manejo orgânico e convencional com as correlações indivicualizadas para os cortes 1,2,3 e 4 em cada sistema, Usina Goiasa, Goiatuba, GO

Tabela 4. Volume de precipitação pluviométrica acumulado $(\mathrm{mm})$ em cada classe de solo em diferentes cortes na região de estudo 59

\section{III - CAPÍTULO II}

Tabela 5. Coeficientes não padronizados relativos ao teste $t$, para os coeficientes da regressão linear múltipla da produtividade da cana-de-açúcar na região de estudo 64

Tabela 6. Descrição morfológica dos perfis de solos LVwf petroplíntico, LVwf, LVwf e

LVdf dos pontos 1 a 4 estudados, respectivamente, na Usina Goiasa, Goiatuba, GO. 82

Tabela 7. Análises químicas dos perfis de solos 1,2,3,4 estudados na Usina Goiasa, Goiatuba, GO. 84

Tabela 8. Análise de micronutrientes dos solos estudados na Usina Goiasa, Goiatuba, GO. 86

Tabela 9. Principais óxidos constituintes dos solos estudados na Usina Goiasa, Goiatuba, GO

Tabela 10. Análises granulométricas dos perfis dos solos 1, 2, 3 e 4 estudados na Usina Goiasa, Goiatuba, GO

Tabela 11. Volume de poros > $30 \mu \mathrm{m}$ (macro e mesoporos) e menores que $30 \mu \mathrm{m}$ (microporos) dos solos estudados na Usina Goiasa, Goiatuba, GO 94

Tabela 12. Água disponível milímetros (média \pm erro) nos quatro solos estudados da Usina Goiasa, Goiatuba, GO 95 
Tabela 13. Potencial hídrico foliar no mês de agosto nos diferentes pares de solos (P1 - LVwf petroplíntico e P2-LVwf; P3 - LVwf e P4 - LVdf) estudados na Usina Goiasa, Goiatuba, GO.

Tabela 14. Médias mensais de precipitação pluviométrica nos anos de 2014 e 2015 na Usina Goiasa, GO. 97

Tabela 15. Produtividade da cana-de-açúcar obtida por pesagem da variedade RB867515, nas diferentes épocas de corte nos solos estudados da Usina Goiasa, $\mathrm{GO}$ 99 


\section{SUMÁRIO}

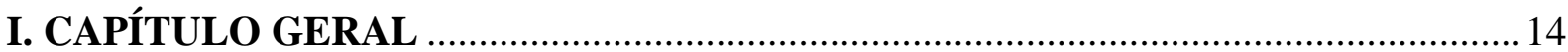

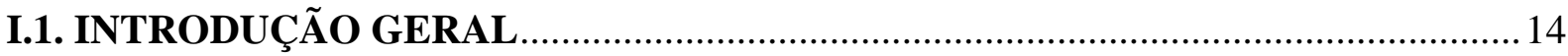

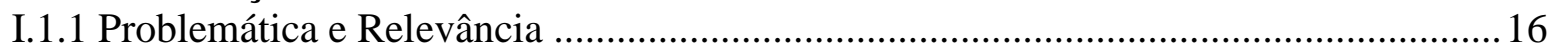

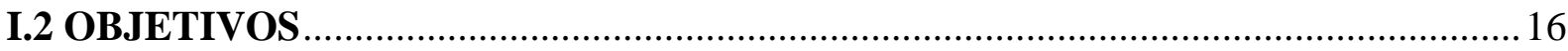

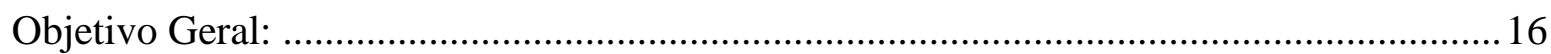

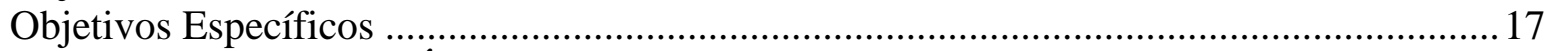

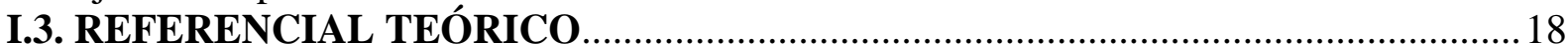

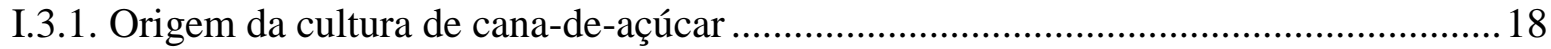

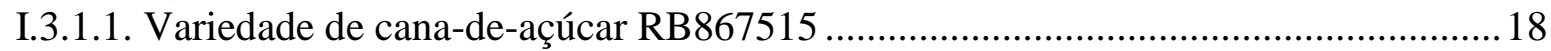

I.3.2. Região do Cerrado Brasileiro e a produção de cana-de-açúcar.................................. 19

I.3.3. Classes de solos e a produtividade da cana-de-açúcar ................................................21

I.3.4. Disponibilidade de água e o desenvolvimento da cana-de-açúcar ..............................23

I.3.5. Clima e o desenvolvimento da cana-de-açúcar ..........................................................2 24

I.3.6. Propriedades químicas dos Latossolos e a produtividade das culturas de cana-de-

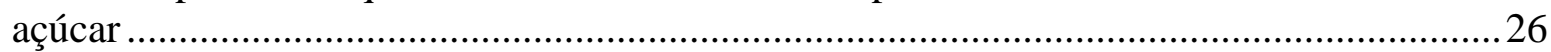

I.3.7. Morfologia e mineralogia de solos e a disponibilidade de água................................28

I.3.8. Caracterização físico-hídrica e a disponibilidade de água dos solos ..........................29

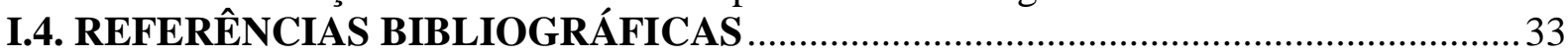

II. CAPITULO 1- FATORES DE PRODUÇÃO DA CANA-DE-AÇÚCAR EM SISTEMA CONVENCIONAL E ORGÂNICO EM LATOSSOLOS FÉRRICOS NA

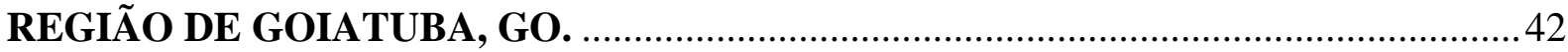

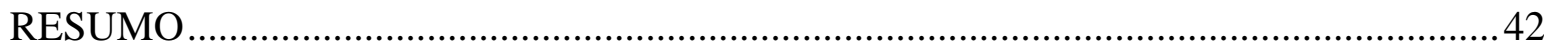

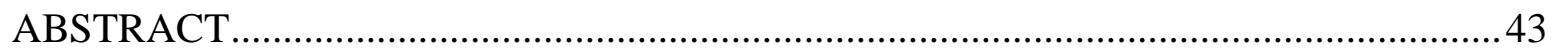

II.1. INTRODUÇÃ

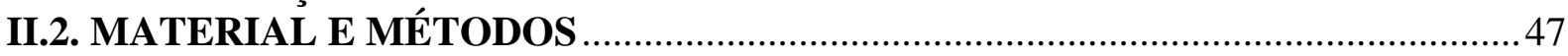

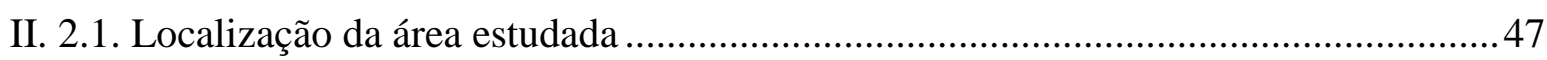

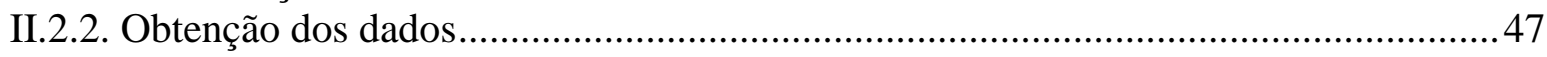

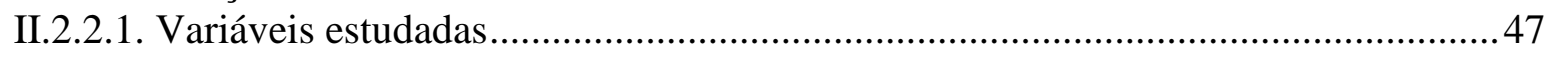

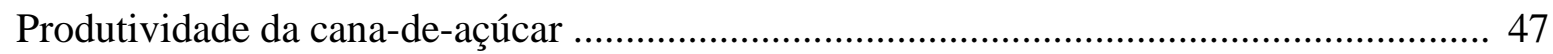

Sistemas de cultivo e classes de solos ......................................................................... 47

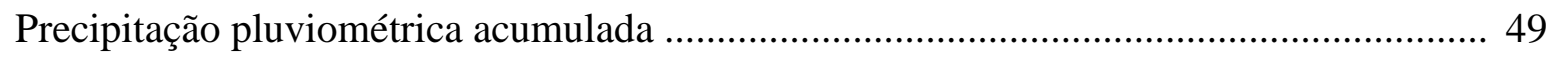

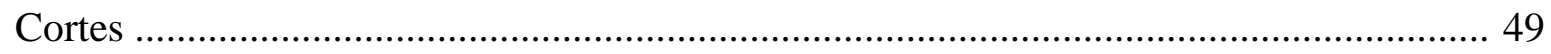

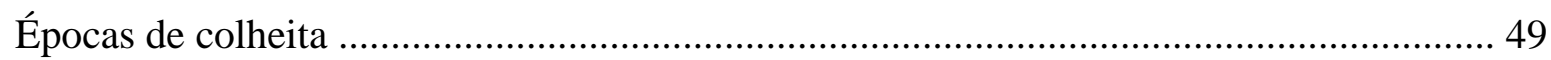

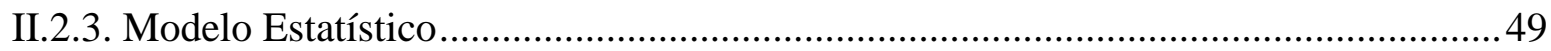

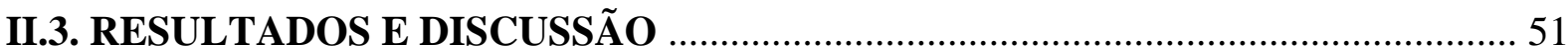

II.3.1. Produtividade média de cana-de-açúcar em diferentes épocas de colheita em sistema

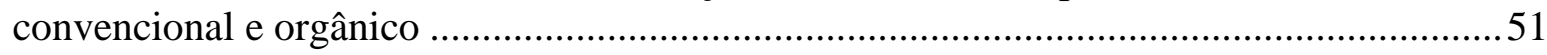

II.3.2. Efeito da época de colheita e da precipitação pluviométrica na produtividade da

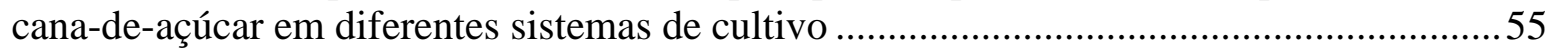

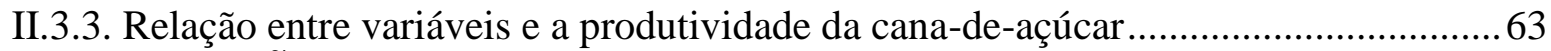

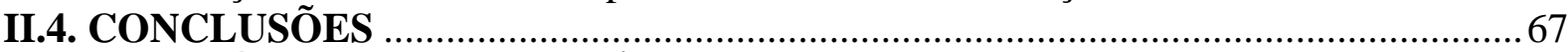

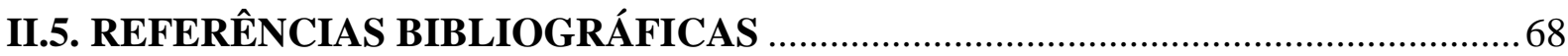

III. CAPITULO 2 - PRODUTIVIDADE DA CANA-DE-AÇÚCAR EM LATOSSOLOS FÉRRICOS NA REGIÃO DE GOIATUBA, GO ..................................................... 72 


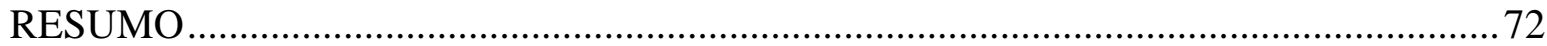

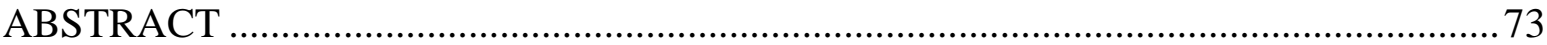

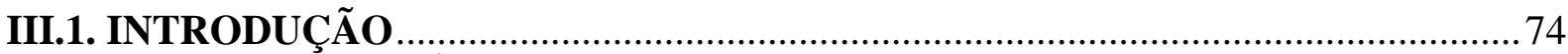

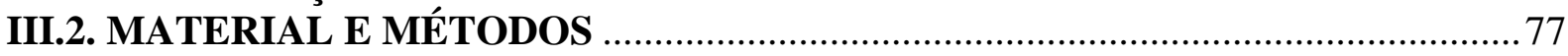

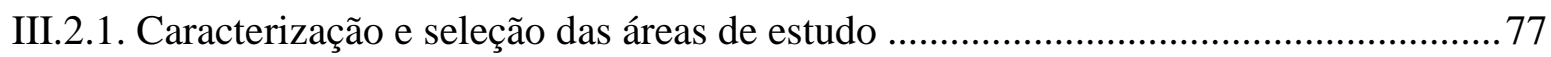

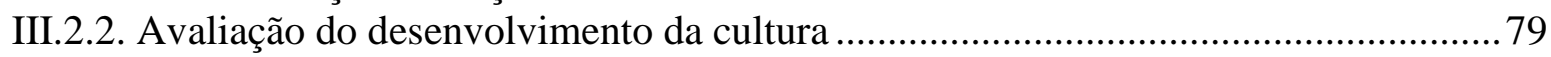

III.2.3. Avaliação da produtividade da cana-de-açúcar .................................................. 79

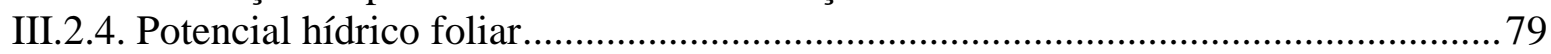

III.2.5. Caracterização morfológica, química e físico-hídrica dos solos estudados...............80

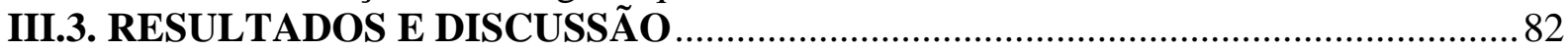

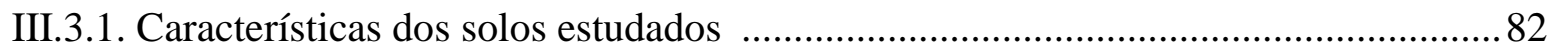

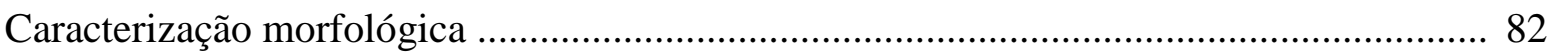

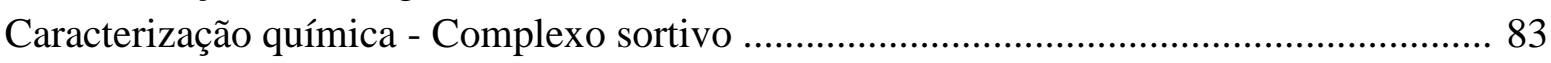

Característização química - Ataque sulfúrico ................................................................ 86

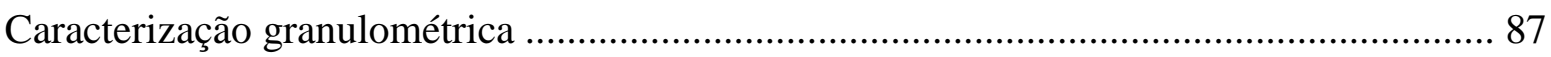

Caracterização físico-hídrica - Densidade do solo e macro, meso e microporosidade ....... 88

III.3.2. Disponibilidade de Água no Solos Estudados ..................................................... 95

Avaliação do potencial hídrico foliar na variedade RB867515 ........................................ 96

III.3.3. Produtividade da variedade de cana-de-açúcar nos solos estudados ........................98

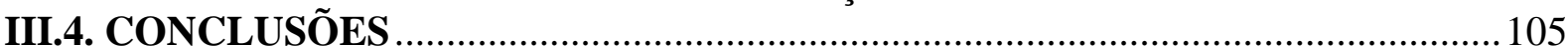

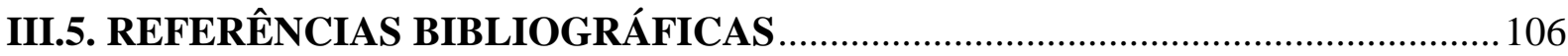

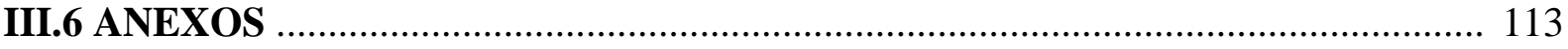




\section{CAPÍTULO GERAL}

\section{I.1. INTRODUÇÃO GERAL}

A cana-de-açúcar é uma cultura de grande valor comercial para o Brasil, de acordo com o senso da safra 2016/2017 da Companhia Nacional de Abastecimento (CONAB, 2016), ocupando uma área superior a 9,07 milhões de hectares, sendo o Brasil o maior produtor mundial de açúcar. A produtividade de cana-de-açúcar em solos brasileiros corresponde a mais de um terço da produção mundial (FAO, 2015). De acordo com CONAB (2016) a região Centro-Oeste é responsável por 19,3\% da área plantada no país, entretanto, em função do manejo adotado nas usinas da região a média de produtividade da cultura nos últimos anos foi superior ao Sudeste brasileiro. O Estado de Goiás destaca-se como o segundo maior produtor de cana-de-açúcar, sendo superado apenas pelo Estado de São Paulo.

Em função do seu extenso sistema radicular, essa cultura é altamente dependente das propriedades químicas de superfície e subsuperfície dos solos (Landell et al., 2003), responsáveis de forma favorável ou desfavorável pelo crescimento, desenvolvimento e longevidade do canavial (Vasconcelos e Casagrande, 2010).

As características pedogenéticas dos solos geralmente não são utilizadas como parâmetros na tomada de decisão para o manejo da maioria das culturas. Entretanto, vários autores, podendo-se citar Joaquim et al. (1997), Prado et al. (2010); Medeiros et al. (2010) e Vasconcelos (2011) entre outros, consideram essas características como fatores importantes na distribuição do sistema radicular e na produtividade das plantas, caracterizando-se, assim, como importantes variáveis na definição do planejamento agrícola.

A maioria das áreas destinadas à agricultura apresentam variações na expressão do potencial produtivo das culturas. Tal fato ocorre em decorrência da manifestação de determinadas características morfológicas dos solos (Mesquita et al., 2007). Em muitas situações estas características não são justificadas como a causa da produtividade das culturas, devido à falta de caracterizações completa do perfil dos solos. As tecnologias atualmente adotadas para intensificar a produção agrícola, priorizam principalmente os atributos físicos e químicos da superfície dos solos (0-20 cm) (Goedert, 1980; Mielniczuk, 2008). Entretanto, observações (Demattê e Demattê, 2009) mostram que a morfologia merece atenção quanto ao manejo das plantas, em especial a cultura da cana-de-açúcar, por sua importância econômica e ambiental na produção de biocombustíveis (Kohlhepp, 2010), e pelas características particulares da cultura, que possui ampla capacidade de explorar o perfil dos solos em maiores profundidades (Vasconcelos e Casagrande, 2010; Landell et al., 2003). Características 
morfológicas que afetam a percolação de água no solo, como a presença de mudança textural abrupta e gradiente textural decorrentes do acréscimo no teor de argila entre os horizontes de superfície e subsuperfície nos solos com horizonte B textural (Maule et al., 2001; Dias et al., 1999), ou a presença de horizontes concrecionários em subsuperfície em Latossolos da região do Cerrado Brasileiro (Mesquita et al., 2007; Campos et al., 2010; Papa et al., 2011) devem ser melhor elucidadas quanto à aptidão agrícola dos solos.

As culturas são dependentes da disponibilidade de água nos solos (Dias et al., 1999), o que torna necessário o estudo das características físico-hídricas dos solos cultivados. No entanto, na maioria das vezes estas características não são avaliadas e consideradas no planejamento de implantação desta cultura. Prado et al. (2010) e Demattê e Demattê (2009) justificam o menor desenvolvimento da cultura de cana-de-açúcar cultivada em Latossolos ácricos devido à baixa água disponível em relação aos Latossolos distróficos. Gross et al. (2013) compararam diferentes genótipos de cana-de-açúcar em distintas localidades da região sudeste de Cuba e concluíram que os solos e o índice pluviométrico foram determinantes na adaptação e produtividade desta cultura.

Na região do Cerrado Brasileiro a distribuição de chuvas varia de 900 a 2000 mm, com a estação seca podendo variar de quatro a sete meses (Adámoli et al., 1985). A variação climática que ocorre nesta região torna determinadas áreas limitantes ao desenvolvimento da cana-de-açúcar, principalmente em solos de baixa capacidade de disponibilizar água.

$\mathrm{Na}$ ocorrência de estresse hídrico no desenvolvimento da cultura, tornam-se restritos alguns processos fisiológicos, tais como: divisão e alongamento celular, diminuindo o acúmulo de massa seca, a taxa de crescimento da cultura e o índice de área foliar (Gonzaga, 2012).

A avaliação do potencial hídrico nas folhas das culturas integra fatores do perfil do solo e expressam a realidade das relações solo-planta-atmosfera (Pincelli, 2010) e provavelmente possam explicar o comportamento da cana-de-açúcar em classes de solos distintos, visto que resultados de avaliação da água disponível nos solos por meio dos métodos de laboratório geralmente não demonstram diferenças. Portanto, o estudo das propriedades químicas, características morfológicas e dos atributos físico-hídricos dos solos cultivados com cana-de-açúcar devem ser avaliados para o correto manejo agrícola dos solos, podendo identificar causas de alterações do comportamento produtivo da cana-de-açúcar. 


\section{I.1.1 Problemática e Relevância}

A cana-de-açúcar é uma cultura de grande valor econômico para o país, sendo o Brasil o maior produtor de açúcar e o segundo maior na produção de etanol. Considerada uma planta cosmopolita é cultivada nas principais regiões brasileiras. Entretanto, por ser uma planta perene e devido à boa capacidade do sistema radicular em desenvolver-se em profundidade a cultura expressa seu potencial de forma variável em função do solo na qual é cultivada. O Estado de Goiás é o segundo maior produtor de cana-de-açúcar no Brasil, onde, os solos que predominam nesse estado são os Latossolos, considerados muito profundos, ácidos, de baixa fertilidade natural e baixa disponibilidade hídrica. Entretanto, observações em áreas cultivadas com tal cultura, demonstram grande variabilidade no potencial produtivo da canade-açúcar nessa classe de solo, principalmente os Latossolos com os caracteres distroférricos e acriférricos, comuns na região Sul do Estado de Goiás. Apesar de quimicamente semelhantes, esses solos demonstram produtividade distinta em cada ano agrícola. Em períodos com maior déficit hídrico, a cana-de-açúcar cultivada nos Latossolos acriférricos têm baixo desenvolvimento e a cultura demonstra estresse hídrico, podendo recuperar-se rapidamente em períodos com intensa precipitação pluviométrica, porém, o potencial produtivo é inferior em relação as áreas cultivadas em Latossolos distroférricos. Entretanto, ao analisar a água disponível nas duas classes de solos os valores são semelhantes, o que torna difícil a individualização do manejo de maneiras distintas. Desta forma, torna-se importante estudos sobre o efeito da precipitação pluviométrica e da caracterização morfológica e dos atributos físico-hídricos dos Latossolos Vermelhos Distroférricos e Acriférricos do Sul do Estado de Goiás, além disso, comparar métodos que avaliem o potencial hídrico na cana-deaçúcar como possível alternativa no entendimento da dinâmica da água e na distinta produtividade da cultura em ambos os solos.

\section{I.2 OBJETIVOS}

\section{OBJETIVO GERAL:}

Avaliar a influência das características morfológicas e físico-hídricas de Latossolos Vermelhos Acriférricos e Distroférricos na produtividade da cana-de-açúcar no sul de Goiás. 


\section{OBJETIVOS ESPECÍFICOS}

1- Avaliar o efeito das classes de solos, precipitação pluviométrica, épocas de colheita, número de cortes e sistemas de cultivo na produtividade da cana-de-açúcar no Sul de Goiás.

2 - Caracterizar os Latossolos Vermelhos Distroférricos e Acriférricos da Usina Goiasa, ambos cultivados com a variedade de cana-de açúcar RB867515, no terceiro e quarto cortes, por meio de análises pedomorfológicas e químicas e físico-hídricas.

3 - Avaliar a produtividade da cana-de-açúcar, variedade RB867515, por meio de cortes em diferentes épocas de safras (maio, agosto e outubro), em Latossolos Vermelhos Distroférricos e Acriférricos na Usina Goiasa.

4 - Estimar o potencial hídrico de base da cultura da cana-de-açúcar e relacionar com a produtividade da cultura. 


\section{I.3. REFERENCIAL TEÓRICO}

\section{I.3.1. Origem da cultura de cana-de-açúcar}

A cana-de-açúcar pertence à família Poaceae e ao gênero Saccharum que contempla várias espécies como S. officinarum L., S. spontaneum L., S. robustum J., S. sinnensis R. e S. barberi J., porém, atualmente para a exploração comercial são utilizados genótipos híbridos.

De acordo com Figueiredo (2010), é uma planta perene adaptada a climas tropicais e subtropicais. Apesar da divergência existente entre vários autores sobre o centro de origem da cultura, estima-se que o local contemple a região Sudeste da Ásia.

Segundo Miranda (2008), no ano de 1532, as primeiras mudas da cultura, foram introduzidas no Brasil por Martim Afonso de Souza na capitania de São Vicente, Estado de São Paulo, e essas eram naturais da Ilha da Madeira e da Região dos Açores, cujas condições climáticas eram semelhantes ao do país sul-americano (Chaves et al., 2003).

Apesar de a cultura chegar primeiro na capitania de São Vicente, foi nos Estados da região nordestina (Bahia e Pernambuco) que ela obteve grande expansão nacional por muitos anos. Posteriormente, por motivos econômicos a cultura expandiu para o Estado de São Paulo. Segundo Figueiredo (2010) a cultura continua sua expansão nas regiões tradicionais e atingindo novas fronteiras (Oeste de São Paulo, Minas Gerais, Goiás, Mato Grosso, Mato Grosso do Sul) em grande escala.

\section{I.3.1.1. Variedade de cana-de-açúcar RB867515}

Em meados dos anos 70 e extinto em 1990 o PLANALSUCAR (Programa Nacional de Melhoramento da Cana-de-Açúcar e do Programa de Racionalização da Agroindústria Canavieira) atuou no programa de melhoramento genético em todas as regiões produtoras da cana-de-açúcar.

Em 1991, toda sua estrutura física e de recursos humanos foi incorporada às universidades federais, que unificaram as pesquisas sobre a cultura através da rede interuniversitária para o desenvolvimento sucroalcooleiro denominado RIDESA (Figueiredo, 2010).

A Ridesa é considerada a líder em desenvolvimento de variedades de cana-de-açúcar e a sigla RB (República Federativa do Brasil) ocupa 65\% do plantel de material em nível nacional, que desenvolve parcerias com 95\% das unidades sucroalcooleiras (Novacana, 2015). Em 1985 a Coordenadoria Regional Centro (COCEN) sediada em Ponte Nova (MG) foi 
criada com a finalidade de atender as demandas de variedades dos estados de Minas Gerais e Goiás. Em 1999 o plantio do clone 15, já batizado como RB867515 foi realizado pela usina Jatiboca em solos de baixa fertilidade em três épocas de corte (maio, julho e novembro) sendo também avaliados nos estados do Paraná (UFPR) e São Paulo (UFSCar). Apesar do difícil período de transição do PLANALSUCAR para a Ridesa, a variedade RB867515 foi lançada oficialmente como variedade comercial em março de 1997, pela Universidade Federal de Viçosa (UFV) (Ridesa, 2010). Atualmente a variedade de cana-de-açúcar RB867515 ocupa $26 \%$ do território nacional (Novacana, 2015).

\section{I.3.2. Região do cerrado brasileiro e a produção de cana-de-açúcar}

Segundo Adámoli et al. (1985), o Cerrado abrange uma extensão territorial de $22 \%$ do limite geográfico brasileiro. Este bioma contempla os Estados de São Paulo, Minas Gerais, Goiás, Tocantins, Mato Grosso do Sul, Mato Grosso, Bahia, Maranhão, Piauí, Rondônia, Paraná, e Distrito Federal.

As altitudes variam de 200 a acima de 1000 m, onde grande parte está localizada entre 300 a 900 m (Adámoli et al.,1985). A temperatura média anual varia de $22^{\circ} \mathrm{C}$ no sul a $27^{\circ} \mathrm{C}$ no norte, geralmente associada a mudanças de altitude (Klink e Machado, 2005). A precipitação pluviométrica anual nesta região varia entre 900 e 2000 mm, distribuídos em duas estações distintas: uma seca (com duração de quatro a sete meses) e outra chuvosa. Nos meses de agosto e setembro, períodos mais secos, ocorrem as maiores taxas de evapotranspiração potencial, e consequentemente o maior acúmulo de sacarose na cana-deaçúcar (Lopes e Guilherme, 1994). Cavalcante e Prado (2010) relatam que em regiões com seis meses consecutivos de déficit hídrico o potencial produtivo da cana-de-açúcar se reduz em média em 4,0 t ha-1 em comparação a tabela de ambientes de produção edáfico para a região Centro-Sul do Brasil, segundo Prado et al., (2010), ou seja, o potencial hídrico da região determinou o ambiente de produção da região de Araxá-MG.

Na Região do Cerrado Brasileiro, os Latossolos são predominantes (Adámoli et al. 1985; Correia et al. 2002). Esses solos apresentam avançado grau de intemperismo, geralmente com caráter químico distrófico, sendo muitas vezes ácricos. No entanto, esse carácter não é devidamente identificado, pois em análises químicas de rotina o $\mathrm{pH}$ em $\mathrm{KCl}$ e o cálculo da retenção de cátions $\left(\mathrm{RC}=\left(\mathrm{SB}+\mathrm{Al}^{3+} / \%\right.\right.$ argila $\left.) \times 100\right)$ nas camadas subsuperficiais não são realizados, atribuindo em muitos casos o desconhecimento deste importante caráter químico. Cabe salientar que a inclusão desse caráter (Oliveira et al., 1992) passou a ser utilizado no Sistema Brasileiro de Classificação de Solos em sua primeira edição 
em 1999 (Embrapa, 1999), como caráter previsto nas classes dos Latossolos e Plintossolos. Esse critério foi proposto por Bennema et al. (1959) citados em Embrapa (2013), sendo os solos classificados anteriormente àquela época como Distróficos, mesmo quando apresentavam caráter ácrico.

Entretanto, Ministério de Agricultura (1960) foram os pioneiros a relatar em suas descrições de perfis de solos sob a vegetação do Cerrado, valores de $\Delta \mathrm{pH}$ positivo em subsuperfície.

De acordo com Uehara (1988) solos ácricos são de rara ocorrência, sendo mais comum sua presença nas paisagens mais intemperizadas da África, Ásia, Austrália e América do Sul. No Brasil, Cury e Franzmeier (1984); Oliveira et al. (2010) relatam a presença de Latossolos Vermelhos Distroférricos e Acriférricos, respectivamente nos municípios de Itumbiara e Jataí ambos no estado de Goiás. Oliveira e Prado (1987) relataram a presença de Latossolos com o caráter ácrico no município de Guaíra, estado de São Paulo, o mesmo descrito por Leite et al. (2009) no Estado do Mato Grosso.

O baixo potencial químico dos solos ácricos é expressivo pela própria definição quanto a baixa CTC efetiva quando comparados aos solos distróficos, principalmente nos teores de cálcio ( $\mathrm{Ca}$ ) no horizonte Bw (Landell et al., 2003). Entretanto, no que se refere ao alumínio trocável $\left(\mathrm{Al}^{3+}\right)$, tóxico às plantas, nos solos de caráter ácrico os teores são baixos a nulos, enquanto nos solos distróficos podem ser nulos a elevados (Lopes e Cox, 1977; Embrapa, 2013).

De maneira geral, os Latossolos do Cerrado são excessivamente intemperizados, com baixos valores de capacidade de troca de cátions (CTC), muito profundos e com boas características físicas (Goedert, 1980; Kluthcouski et al., 2003).

Até a década de 1970, o Cerrado era tido como de pouca importância no cenário econômico do país. Foi nessa década que por intermédio da iniciativa privada e do Estado, intensificou-se a adoção de práticas agrícolas modernas em uma região considerada atrasada no aspecto econômico.

Com o objetivo de integrar esse bioma ao restante do país e impulsionar a economia regional foi incorporado um modelo que priorizou técnicas modernas de manejo para a agricultura e consequentemente sua urbanização. Toda esta integração e modernização fez a região inserir-se à economia nacional e internacional, passando a constituir "a grande fronteira agrícola do Brasil” (Matos e Pessôa, 2014). Atualmente, o Bioma é a principal região agrícola do país para a produção de monoculturas (cana-de-açúcar, algodão, soja, milho, dentre outras) e pecuária, além da indústria e agroindústria (Chaveiro, 2008; Matos e Pessôa, 2014). De 
acordo com CONAB (2016) os Estados que mais produzem cana-de-açúcar no Cerrado brasileiro são São Paulo, Goiás, Minas Gerais, Mato Grosso do Sul e Mato Grosso. Sendo assim, é fundamental o aprofundamento nos estudos de solos para o melhor conhecimento dos ambientes de produção de cana-de-açúcar no Cerrado brasileiro, para que assim se possa estabelecer sistemas produtivos que sejam sustentáveis e possam gerar o prognóstico das potencialidades e limitações dos solos e seu efeito na produtividade da cana-de-açúcar.

\section{I.3.3. Classes de solos e a produtividade da cana-de-açúcar}

Segundo Landell et al. (2006), um dos aspectos determinantes para o sucesso do manejo varietal da cana-de-açúcar é a determinação dos ambientes de produção. Ambientes de produção de acordo com Prado et al. (2010) é a associação das características e propriedades dos solos de superfície e subsuperfície em determinada condição climática, visando o correta aloção das variedades de cana-de-açúcar em função das potenciliadades e limitações das classes de solos. Dentre os solos com maior potencial para a cultura da canade-açúcar na região Centro-Oeste, Sudeste e Sul do Brasil, Prado et al. (2010) cita os Nitossolos típicos, Chernossolos, Cambissolos com horizonte B espesso e os Argissolos arênicos (Embrapa, 2013) com horizonte B relativamente próximo a superfície. Esses solos proporcionam elevadas produtividades da cana-de-açúcar, devido à maior capacidade de água disponível quando comparados aos Latossolos de textura média, argilosa e muito argilosa de caráter químico, distrófico álico, distrófico e ácrico na mesma região (Demattê e Demattê, 2009). Latossolos de textura argilosa e muito argilosa geralmente apresentam baixa disponibilidade hídrica, devido à forte microagregação da argila no horizonte $\mathrm{Bw}$, que origina micro e macroporosidade elevada cujo movimento e retenção de água são similares aos de solos arenosos (Alleoni e Camargo, 1994).

Segundo Embrapa (2013), a morfologia do horizonte B dos Nitossolos deve apresentar estrutura em blocos angulares e subangulares, ou prismática (moderada ou forte), com nítidas superfícies brilhantes interpretadas como cerosidade, e/ou superfícies de compressão, e essa morfologia tem forte influência no valor da umidade na capacidade de campo, na condutividade e retenção hídrica pelo solo (Cooper e Vidal-Torrado, 2005).

Cooper e Vidal-Torrado (2005) estudaram numa mesma topossequência o comportamento físico-hídrico de um Nitossolo Vermelho Eutroférrico típico e um Nitossolo Vermelho Eutroférrico latossólico, concluindo que a cerosidade e a estrutura em blocos, presente em todo o horizonte B do Nitossolo Vermelho Eutroférrico típico, aumentaram a retenção de água e diminuíram a condutividade hidráulica do solo em função da distinta 
distribuição da porosidade no perfil do solo. No Nitossolo Vermelho Eutroférrico latossólico ocorreu o contrário, a transição para o horizonte B com características latossólicas diminuiu a retenção e aumentou a condutividade hidráulica devido à maior comunicação dos poros ao longo do perfil do solo.

De acordo com Vitti e Prado (2012), ao comparar o potencial produtivo da cana-deaçúcar na região de Piracicaba-SP em Nitossolo Vermelho Eutrófico e Latossolo Vermelho Álico, Latossolo Vermelho Distrófico álico, este corrigido com calcário e gesso, os autores obtiveram produtividade $11 \%$ superior (15 toneladas) para a cana-de-açúcar cultivada em Nitossolo Vermelho Eutrófico. A maior produtividade no Nitossolo foi devido ao caráter eutrófico e à elevada disponibilidade hídrica, que segundo Prado (2011) é de 125 a 150 $\mathrm{mm} . \mathrm{m}^{-1}$ de solo para os Nitossolos, enquanto que para os Latossolos é de 60 a $80 \mathrm{~mm} . \mathrm{m}^{-1} \mathrm{de}$ solo.

Pádua Junior et al. (2007) estudando o desenvolvimento da variedade de cana-deaçúcar SP813250 em Latossolo Vermelho Distroférrico e Cambissolo Háplico Tb Distrófico petroplíntico, concluíram que a presença da petroplintita formou uma barreira física para a movimentação de água nos Cambissolos em subsuperfície, que permitiu o melhor aproveitamento de água no crescimento e desenvolvimento da cana-de-açúcar apesar da condição química mais limitante neste solo com saturação de alumínio (m\%) superior a 50\%.

Briza et al. (2009) ao estudar o efeito dos ambientes de produção para cana-de-açúcar verificaram que houve uma melhor condição físico-hídrica no Cambissolo profundo em função do maior teor de silte, apesar da condição química desfavorável, que proporcionou a variedade SP801816 uma produtividade média superior a $100 \mathrm{t} \mathrm{ha}^{-1}$ na média de cinco cortes. Costa et al. (2013) comparou a retenção e a disponibilidade hídrica de diversos solos de textura, arenosa, siltosa, argilosa e muito argilosa, e concluíram que solos argilosos e siltosos têm maior retenção de acordo com a curva de retenção de água no solo.

Ferreira et al. (2007) estudaram o surgimento da vegetação nativa de Campinas-SP, com base na disponibilidade hídrica por classe de solo. Um dos fatores que os autores correlacionaram para a influência da vegetação de Cerrado em áreas de Latossolos foi a baixa disponibilidade de água. O predomínio de Argissolos e Nitossolos com elevada água disponível nos horizontes $\mathrm{B}$ textural e $\mathrm{B}$ nítico, respectivamente, decorrente da morfologia desses horizontes, possibilitaram o surgimento das matas (Floresta tropical subcaducifólia). Segundo Reichardt e Timm (2008), o horizonte B textural possui condutividade hídráulica da ordem de 10 vezes menor em relação ao horizonte superior no mesmo solo (horizonte A). 
Pissarra et al. (2004), estudando características morfométricas em bacias hidrográficas na região de Jabotical-SP, observaram que a capacidade de infiltração de água do Argissolo é muito menor que a do Latossolo. Portanto, a baixa condutividade hídrica no horizonte B textural, traduz em menores índices de percolação de água, ou seja, o solo permanece por mais tempo com teor de água próximo da capacidade de campo no horizonte Bt, possibilitando a maior quantidade de água no perfil e maior absorção pelas raízes das plantas.

Segundo Prado et al. (2010), somente a umidade em volume da capacidade de campo e o ponto de murcha permanente não quantificam a capacidade de água disponível (CAD) em solos heterogêneos. O autores consideram um índice $(m)$ relacionado à influência da morfologia em Nitossolos, Argissolos arênicos, Chernossolos e Cambissolos, considerados pelos pesquisadores como solos que proporcionam o melhor desenvolvimento da cana-deaçúcar, nos quais o valor de m é maior do que nos Latossolos $(\mathrm{m}=1)$.

\section{I.3.4. Disponibilidade de água e o desenvolvimento da cana-de-açúcar}

A cultura da cana-de-açúcar em determinadas condições de clima exige um volume hídrico de 1.500 a $2.500 \mathrm{~mm}$ para completar o ciclo fenológico (Ometto, 1980), entretanto, é cultivada em regiões com menor índice pluviométrico (Brunini, 2010). A cultura apresenta elevado consumo de água, necessitando, em média de 250 partes de água para formar uma parte de matéria seca durante todo período de crescimento (Larcher, 2004; Taiz e Zeiger, 2009). Dalri e Cruz (2008) relatam que a água constitui $71 \%$ da massa fresca da cana-deaçúcar.

Na ocorrência de estresse hídrico no desenvolvimento da cultura ocorrem restrições nos processos fisiológicos, tais como: divisão e alongamento celular, diminuindo o acúmulo de massa seca, a taxa de crescimento da cultura e o índice de área foliar (Gonzaga, 2012). O potencial hídrico foliar expressa o status de água na planta, que é função da distribuição de água disponível e raízes no perfil, além da demanda evapotranspirativa no sistema soloplanta-atmosfera. Segundo Pincelli (2010), a medida de água na planta indica ser uma importante ferramenta na avaliação do estresse hídrico entre as variedades de cana-de-açúcar. Entretanto, Rodolfo Júnior (2015) relata que as diferenças de aproveitamento de água pelas variedades de cana-de-açúcar, dentre elas a RB867515 é atribuída em função de mecanismos estomáticos específicos de cada variedade. 


\section{I.3.5. Clima e o desenvolvimento da cana-de-açúcar}

De acordo com Brunini (2010), a cana-de-açúcar é cultivada entre as latitudes $35^{\circ}$ Norte e $35^{\circ}$ Sul. O ciclo de crescimento da planta varia de nove meses a mais de dois anos, conforme sua posição geográfica. Os fatores climáticos mais limitantes para o desenvolvimento da cultura são a temperatura do ar e o índice de chuvas. Cultivadas em temperaturas entre 30 e $34^{\circ} \mathrm{C}$ a cana-de-açúcar tem intenso crescimento, em temperaturas superiores o crescimento é reduzido, o mesmo observado em valores inferiores a $21^{\circ} \mathrm{C}$.

Em regiões tradicionais no cultivo da cana-de-açúcar, o índice de precipitação pluviométrica é de 1000 a 1600 mm, cuja melhor resposta da cultura é obtida em locais com boa distribuição de chuvas durante o ciclo de crescimento.

De acordo com Brunini (2005) fatores como o sistema radicular e o tipo de solo deveriam ser considerados para estimar os limites reais de retenção de água no solo.

Prado (2011) relata que no Nordeste a produtividade média da cana-de-açúcar é inferior à região Centro-Sul do país em função do maior deficit hídrico e obedece a seguinte ordem decrescente de potencial produtivo em função do solo cultivado:

$1^{\text {a }}$ Gleissolos Melânicos Eutróficos e Distróficos;

$2^{\text {a }}$ Gleissolos Háplicos Distróficos e Distróficos álicos;

$3^{\text {a }}$ Cambissolos Háplicos Eutróficos e Distróficos;

$4^{\mathrm{a}}$ Argissolos Amarelos e Vermelho- Amarelos Distróficos arênicos;

$5^{\text {a }}$ Latossolos Amarelos Distróficos, Acriférricos e Ácricos de textura argilosa a muito argilosa;

$6^{\text {a }}$ Latossolos Amarelos Distróficos, de textura média (26 a 35\% de argila);

$7^{\mathrm{a}}$ Latossolos Amarelos Distróficos, de textura média (15 a 25\% de argila);

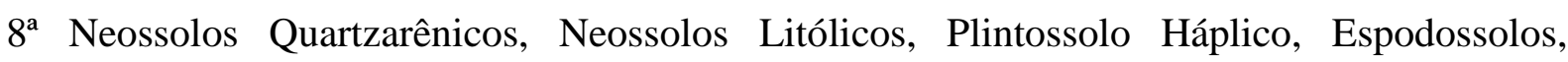
Vertissolos e Gleissolos Tiomórficos.

Todos os solos acima mencionados em condições de sequeiro. Entretanto, Silva e Amaral (2011) relatam que apesar da condição salina dos Vertissolos nordestinos em sistema irrigado, a produtividade média foi de $180 \mathrm{t} \mathrm{ha}^{-1}$, muito superior se comparado à média nacional em áreas de sequeiro que está em torno de 76,15 t ha ${ }^{-1}$ (CONAB, 2016). Na região Centro-Sul do Brasil, a maior quantidade e distribuição de precipitação pluviométrica durante o ano, proporciona ambiente mais favorável e maiores produtividades da cana-de-açúcar se comparado à região Nordestina (Nunes Junior et al., 2005), sendo cada vez mais distintas em função das anomalias ocorridas na região (CONAB, 2016). Com exceção das áreas irrigadas, a disponibilidade hídrica é ordenada pela precipitação pluviométrica e pela capacidade do 
solo em armazenar água (Maule et al., 2001). Landell et al. (2006) correlacionou a condição química pedológica dos Latossolos às produtividades em diferentes épocas de corte da canade-açúcar e denominou esta associação como matriz ambiental.

As épocas de corte foram divididas em começo (outono), meio (inverno) e final de safra (primavera) e as condições químicas em favoráveis, médios e desfavoráveis. Esta matriz permite importantes informações de manejo, pois a cana-de-açúcar tem seu potencial produtivo reduzido do início para o final da colheita, devido à falta de precipitação pluviométrica durante o desenvolvimento, independentemente da condição química do solo. Entretanto, para os solos desfavoráveis esta perda de produtividade é mais acentuada principalmente em regiões de clima mais quente e seco (Demattê e Demattê, 2009).

Na Figura 1 o desenvolvimento da cana-de-açúcar em Latossolo Vermelho Ácrico de textura argilosa, em condições de baixos índices pluviométricos, no Estado de Goiás (Prado, 2011).

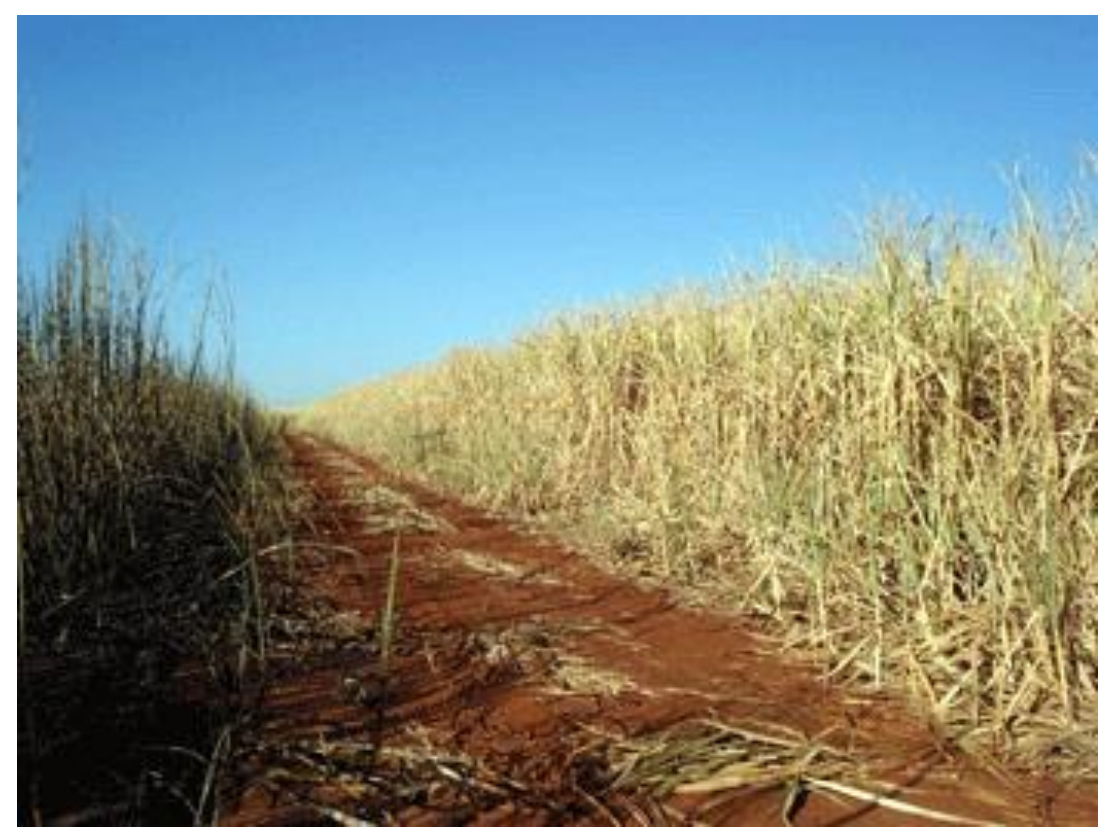

Figura 1. Aspecto de amarelecimento da cana-de-açúcar em Latossolo Vermelho Ácrico de textura argilosa. Fonte: Prado (2011).

Entretanto, quando a água é oferecida artificialmente, o desenvolvimento da cana-deaçúcar é vigoroso, conforme observado na Figura 2, em destaque a variedade de cana-deaçúcar RB867515 em Latossolo Vermelho Distroférrico com irrigação por gotejamento, com produtividades superiores a $200 \mathrm{tha}^{-1}$. 


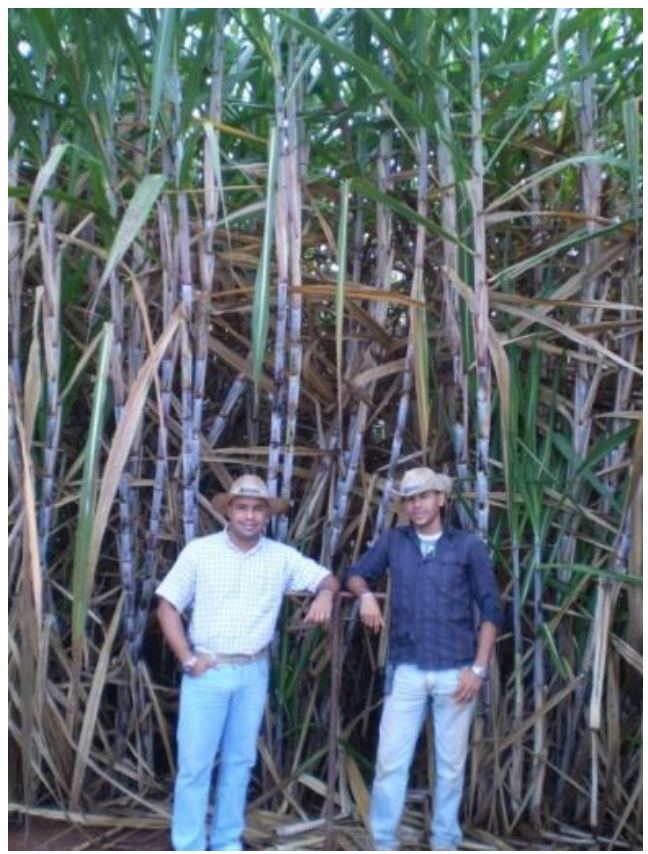

Figura 2. Variedade RB867515 cultivada em Latossolo Vermelho Distroférrico sob sistema de irrigação por gotejamento. Foto obtida em 25/08/2008. Fonte: Foto do autor.

\section{I.3.6. Propriedades químicas dos Latossolos e a produtividade das culturas de cana-de- açúcar}

Latossolos são considerados a classe de solo de maior ocorrência do Brasil, ocupando mais de 50\% do território nacional (Oliveira, 1992). Lepsch, (2011) relata que no Brasil existe um quarto dos Latossolos do mundo, com uma área correspondente a 300 milhões de hectares.

O caráter químico dos Latossolos varia de eutrófico a alumínico, podendo ter teores de óxidos de ferro variáveis cuja denominação: hipoférrico, mesoférrico, férrico, perférrico, são dos menores aos maiores teores de hematita no solo (Embrapa, 2013) os Latossolos Eutroférricos, principalmente originados das rochas ígneas básicas da Formação Serra Geral, tais como o basalto e o diabásio são os mais produtivos para culturas anuais e perenes (Oliveira, 2005).

Segundo Landell et al. (2003), um dos fatores que afetam a produtividade da cana-deaçúcar e principalmente das soqueiras é a condição química de subsuperfície a partir da terceira safra, cuja ordem decrescente é a seguinte: eutrófico > mesotrófico > distrófico > ácrico > álico. De acordo com Dias et al. (1999) as propriedades químicas pedológicas, tais como: saturação por bases (V\%), soma por bases (SB), saturação por alumínio (m\%), pH e matéria orgânica (MO) de distintas classes de solos associadas a condição climática de 
diferentes municípios do Estado de São Paulo afetaram a capacidade produtiva de seis variedades da cana-de-açúcar.

Prado (2011) enfatizou as condições químicas pedológicas denominadas de mesotrófico e mesoálico, subdividindo os solos classificados no Sistema Brasileiro de Classificação do Solo - SiBCS Embrapa (2013) como distróficos, sendo os solos mesotróficos caraterizados por:

Saturação por bases (V\%) entre 30 a $50 \%$, soma de bases (SB) maior ou igual a 1,2 $\mathrm{cmol}_{c} \mathrm{dm}^{-3}$ solo ou $\mathrm{V} \%>50 \%$ e SB menor $1,5 \mathrm{cmol}_{\mathrm{c}} \mathrm{dm}^{-3}$ solo e retenção de cátions (RC) superior a $1,5 \mathrm{cmol}_{\mathrm{c}} \mathrm{dm}^{-3}$ de argila.

Os solos mesoálicos são descritos como: Saturação por bases (V\%) < 50\%, saturação por alumínio (m\%) entre 15 a 50\%, com teores de alumínio (Al) entre 0,4 a 4,0 $\mathrm{cmol}_{\mathrm{c}} \mathrm{dm}^{-3}$ solo e RC superior a 1,5 $\mathrm{cmol}_{\mathrm{C}} \mathrm{dm}^{-3}$ de argila. Entretanto, essa subdivisão química é relatada por Demattê e Demattê (2009) como uma possível dificuldade na distinção das unidades de mapeamento das usinas que não utilizam a legenda proposta pelo Instituto Agronômico.

De acordo com Joaquim et al. (1997) e Landell et al. (2003) os Latossolos ácricos e acriférricos têm reduzidos teores de cálcio no horizonte Bw (B latossólico) e são considerados de baixo potencial produtivo para a cultura da cana-de-açúcar. Já Oliveira (2005) relata que os Latossolos ácricos possuem baixos teores de alumínio e capacidade de troca de ânions (CTA) superior à capacidade de troca de cátions (CTC) no horizonte $\mathrm{Bw}$, tornando tais solos improdutivos em locais de baixo nível de tecnologia, porém em locais totalmente mecanizados, com adoção de práticas de correção do solo, adubação e irrigação entre outros, proporcionam elevadas produtividades, principalmente em culturas anuais. Joaquim et al. (1997) enquadram os melhores ambientes de produção para os solos distróficos e distroférricos em relação aos solos ácricos e acriférricos. Na tabela de ambientes de produção para a cultura da cana-de-açúcar proposta por (Prado et al., 2010), são descritas para os Latossolos as características químicas e físico-hídricas avaliadas pelo autor como capacidade de troca de cátions (CTC) na camada superficial, característica química de subsuperfície e a água disponível.

A Figura 3 mostra o desenvolvimento da cana-de-açúcar RB867515 em terceiro corte em Latossolo Vermelho Distrófico de textura média (a) e em Latossolo Vermelho Acriférrico de textura argilosa (b) evidenciando o baixo desenvolvimento da cana-de-açúcar em solos ácricos no estado do Maranhão. 

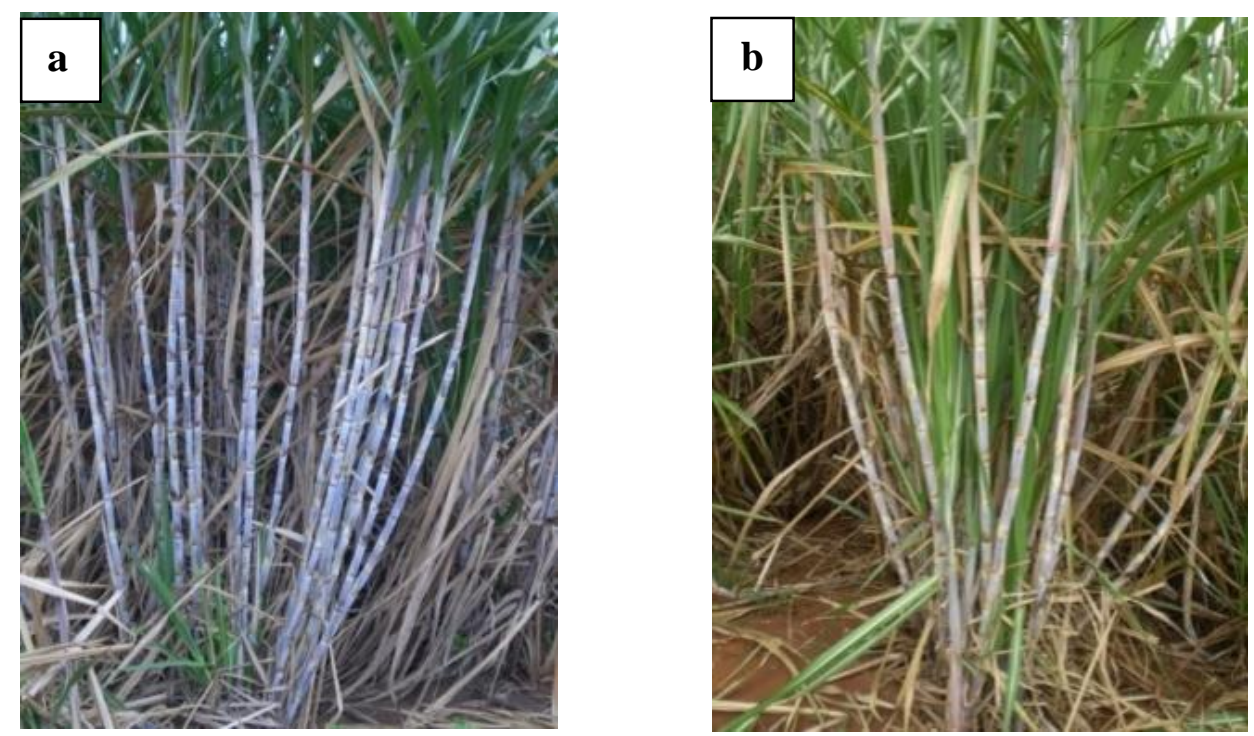

Figura 3. Desenvolvimento da variedade RB867515 em Latossolo Vermelho Distrófico (a) Latossolo Vermelho Ácrico (b), ambos no terceiro ciclo vegetativo no estado do Maranhão. Foto obtida em 26/08/2008. Fonte: Fotos do autor.

Apesar da condição química isoladamente não ser o fator principal para a qualificação dos ambientes de produção para a cultura da cana-de-açúcar, Prado e Pádua Junior, (2006), o caráter químico dos solos é considerado um dos fatores que compõe os componentes dos ambientes de produção, o qual se associa a textura, profundidade e disponibilidade hídrica (Prado et al., 2010).

Segundo Rossetto et al. (2013), Latossolos com o mesmo teor de argila podem ter a capacidade de água disponível distinta em condições químicas subsuperficiais diferentes. Nesse mesmo trabalho os autores relatam um Latossolo Vermelho Álico, e um Latossolo Vermelho Distrófico álico (Embrapa, 2013) de textura muito argilosa (> 60\% de argila), com menor quantidade de água disponível que um Latossolo Vermelho de textura média, 15 a 25\% de argila em todo perfil, porém de caráter químico eutrófico.

\section{I.3.7. Morfologia e mineralogia de solos e a disponibilidade de água}

O manual de descrição e coleta de solo no campo (Santos et al., 2013) descreve várias características morfológicas do solo, influenciadas pela sua mineralogia e que interferem na dinâmica de água para as plantas, podendo criar conceitos os quais podem se correlacionar ao crescimento, desenvolvimento e produtividade das culturas (Dias et al., 1999; Mesquita et al., 2007; Campos et al., 2010; Cavalcante e Prado, 2010; Papa et al., 2011 e Vitti e Prado, 2012). Severiano et al. (2010) estudaram o potencial de uso do Latossolo Vermelho Amarelo Distrófico e o Cambissolo Háplico Tb Distrófico em áreas da cana-de-açúcar, no município de Goianésia-GO. Os autores concluíram que a elevada disponibilidade hídrica e a maior 
resistência à compactação no Cambissolo Háplico Tb Distrófico foi devido a sua estrutura disposta em blocos.

Os Latossolos são caracterizados pelo acúmulo de caulinita e óxidos insolúveis de ferro (goethita e hematita) e alumínio (gibbsita) em função da intensa perda de sílica (dessilicatização) (Uehara, 1988), devido ao elevado grau de intemperismo destes solos.

Segundo Alleoni e Camargo (1995), os óxidos de ferro e alumínio influenciam os atributos eletroquímicos de solos altamente intemperizados dos trópicos. Alleoni e Camargo (1994) relatam que os elevados teores de óxidos indicam solos altamente intemperizados e consequentemente baixos valores dos índices de intemperismo $\mathrm{Ki}$ e $\mathrm{Kr}$ e elevam o ponto de carga zero (PCZ) de Latossolos brasileiros.

Quanto maior a participação destes óxidos na fração argila do solo, maior é o PCZ, principalmente nos horizontes subsuperficiais, já que o PCZ dos óxidos é alto (entre 7,5 e 9,0). Latossolos com o caráter químico ácrico são os mais intemperizados desta classe de solo, possuem reduzida capacidade de troca de cátions (CTC) e o aumento da capacidade de troca de ânions (CTA) na subsuperfície (Oliveira, 2005), interferindo na dinâmica de cátions trocáveis destes solos.

Os Latossolos ácricos de textura argilosa e muito argilosa geralmente apresentam baixa disponibilidade de água, em função da forte microagregação da argila no horizonte $\mathrm{Bw}$, que origina micro e macroporosidade elevada (Alleoni e Camargo, 1994) cujo movimento e retenção de água são similares aos de solos arenosos (Oliveira e Prado, 1987).

\section{I.3.8. Caracterização físico-hídrica e a disponibilidade de água dos solos}

O conhecimento da distribuição dos poros dos solos é uma importante ferramenta para o manejo de áreas agrícolas. Apesar de não existir um consenso entre os pesquisadores sobre a classificação do diâmetro para os diferentes poros, de forma conceitual os microporos, são os poros responsáveis pela retenção da água no solo, enquanto os macroporos representam os poros responsáveis pela drenagem e aeração do solo (Brady, 1979). A classificação da distribuição do tamanho de poros proposta por Koorevaar et al. (1983), que estabelece macroporos $(>100 \mu \mathrm{m})$, mesoporos $(100 \leq \mathrm{a} \geq 30 \mu \mathrm{m})$ e microporos $(<30 \mu \mathrm{m})$, indica ser um método importante para a avaliação em áreas agrícolas e nos ambientes naturais (Torres et al., 2014).

De maneira inversamente proporcional ao volume total de poros, a densidade do solo, também interfere no manejo das culturas no campo ao atribuir maior resistência ao desenvolvimento de raízes e a infiltração de água no solo. Fatores como tráfego de máquinas, 
sistema de cultivo adotado, textura e material de origem dos solos controlam seu valores. Ceddia et al. (1999) identificaram valores de Ds superiores a $1,5 \mathrm{~g} \mathrm{~cm}^{-3}$ até $40 \mathrm{~cm}$ de profundidade de Argissolos Amarelos arenosos de tabuleiro, sob sistema de cana-de-açúcar colhida crua e queimada, do município de Linhares, Estado do Espírito Santo. Klein e Libardi (2000) relataram o limite de Ds de $1,11 \mathrm{~g} \mathrm{~cm}^{-3}$ para o maior armazenamento de água em Latossolo Vermelho Ácriférrico de textura muito argilosa do município de Guaíra, Estado de São Paulo.

Em se tratando de métodos físicos para medir o potencial hídrico no solo, as curvas características de retenção de água são tradicionalmente adotadas pelos laboratórios para obtenção da água disponível (AD). A AD é definida pelo intervalo entre a capacidade de campo (condição após um período de chuva ou irrigação em que os macroporos do solo estão vazios e os microporos com água) e o ponto de murcha permanente (água presente no solo, entretanto, não disponível para absorção pelas plantas).

Métodos laboratoriais que determinam a capacidade de campo de amostras de solos indeformadas e deformadas em geral são consideradas de baixa precisão (Carlesso, 1995). A avaliação em laboratório do conteúdo de água no solo é feita com aplicação de pressão variável, que quando comparados aos métodos estimados no campo, geram divergências, no entanto, grande parte dos pesquisadores e profissionais de física do solo utilizam como estimativa da capacidade de campo a água retida a 33, 10 ou $6 \mathrm{kPa}$. Segundo Van Lier (2010), a capacidade de campo de um solo ocorre quando a taxa de drenagem é considerada desprezível. De acordo com Klein et al. (2006), o potencial matricial de $6 \mathrm{kPa}$ serve como estimativa para determinar a capacidade de campo, por considerar os macroporos do solo vazios neste valor de potencial. Reichardt e Timm (2008) observaram que os valores obtidos no funil de placa porosa a 10 ou $33 \mathrm{kPa}$ não representam a capacidade de campo, tal como medida no campo, pois ao contrário da condição de laboratório, no campo ocorrem processos dinâmicos na redistribuição de água no solo.

De acordo com Klein et al. (2006), a capacidade de campo em solos drenados com estrutura e textura homogênea, normalmente ocorre de dois a três dias após uma irrigação ou precipitação pluviométrica.

Segundo Veihmeyer e Hendrickson (1931), capacidade de campo é a água mantida no solo contra a ação da evaporação e da gravidade, após sua inundação e posterior drenagem livre até quatro dias. Entretanto, Hillel (1980) e (Reichardt, 1988) relatam que a capacidade de campo em alguns solos após a saturação com água pode persistir por vários dias ou até meses. No laboratório a capacidade de campo pode ser estimada pelo uso do funil de placa porosa, 
quando necessário determinar a retenção de água nas amostras do solo em tensões mais baixas $(0,5 ; 1 ; 2 ; 3 ; 5 ; 6 ; 8 ; 10$ e $15 \mathrm{kPa})$ e câmaras de pressão de Richards (Klute, 1986) para as tensões maiores $(33 ; 50 ; 100$ e $1500 \mathrm{kPa})$, podendo medir até o ponto de murcha permanente, PMP. A metodologia que utiliza amostras indeformadas de solos sob efeito de diferentes rotações em centrífuga em função do tempo (Freitas Júnior e Silva, 1984) correlaciona-se de forma positiva com método acima descrito, esse tradicionalmente adotado para avaliação da curva de retenção de água nos solos (Nascimento et al., 2010).

De posse dos valores obtidos, pode-se estimar a CAD pela diferença entre capacidade de campo (CC) (em \% peso) o ponto de murcha permanente (PMP) (\% peso) multiplicado pela densidade do solo $\left(\mathrm{g} \mathrm{cm}^{-3}\right.$ de solo) e dividido por dez, com o valor expresso em $\mathrm{mm}$ por espessura do solo. A capacidade de água disponível é muito utilizada, sua forma de determinar seu valor com base em potenciais matriciais fixos é questionada pela falta de confiabilidade dos valores obtidos (Veihmeyer e Hendrickson, 1949; Sykes, 1969; Reichardt, 1988; Tormena et al., 1999). Os resultados determinados pela curva característica de água no solo possibilitam aplicações científicas e práticas, tais como a capacidade de campo (Ferreira e Marcos, 1983; Fabian e Ottoni Filho, 2000; Mello et al., 2002b), a disponibilidade total de água no solo (Arruda et al., 1987; Centurion e Andrioli, 2000; Mello et al., 2002a), a porosidade drenável (Mello et al., 2002b; Reichardt e Timm, 2008), a condutividade hidráulica do solo não-saturado (van Genuchten, 1980; Wosten et al., 1990; Tomasella e Hodnett, 1997; Reichardt e Timm, 2008), o manejo adequado da irrigação (Mello et al. 2005; Reichardt e Timm, 2008) e o balanço hídrico (Mello et al., 2005).

A disponibilidade hídrica para as plantas só ocorre quando a água se encontra no meio radicular. Esse fato remete à importância da correta determinação da capacidade de campo, que depende da composição do perfil do solo e não se resume em um teor de água a um potencial matricial fixo. Segundo Ruiz et al. (2003) para Neossolos Quartzarênicos e Latossolos com teores de argila de $15 \%$ e $77 \%$, respectivamente, a capacidade de campo se aproxima mais do intervalo dos potenciais matriciais de água no solo de $6 \mathrm{kPa}$ e $10 \mathrm{kPa}$. Araújo et al. (2004) concluíram que os Latossolos Vermelhos Distroférricos de textura muito argilosa do Paraná sob diferentes técnicas de cultivo têm capacidade de campo na tensão de $10 \mathrm{kPa}$. A caracterização da disponibilidade hídrica de alguns Latossolos de textura argilosa a muito argilosa tem demonstrado baixos valores de água disponível, comparados aos valores dos Latossolos de textura média, segundo Alleoni e Camargo (1994) entre outros autores. Segundo Azevedo e Bonumá (2004), os Latossolos possuem forte microagregação da argila floculada conferindo forte infiltração de água, reduzindo o potencial de produtividade das 
plantas. Prado (2011) comparou os valores médios da capacidade de água disponível (CAD) em Latossolos com diferentes teores de argila. Entretanto, o autor concluiu que os valores de CAD nos Latossolos argilosos (não considerando os Latossolos com caráter químico ácrico) são em média 1,6 a 2,42 vezes maiores que nos Latossolos com textura média. A capacidade de armazenamento de água no solo não se relaciona apenas à capacidade de infiltração, mas também a outros fatores como a sequência de horizontes e camadas com propriedades físicas distintas, a composição textural, a umidade inicial, entre outros (Severiano et al., 2010; Reichardt e Timm, 2008). 


\section{I.4. REFERÊNCIAS BIBLIOGRÁFICAS}

ADÁMOLI, J.; MACEDO, J.; AZEVEDO, L.G.; MADERA NETO, J. Caracterização da região dos cerrados. In: GOEDERT, W.J. (Ed.). Solos dos cerrados: tecnologia e estratégia de manejo. Editora Nobel, 1985. p. 33-74.

ALLEONI, L.R.F.; CAMARGO, O.A. Atributos físicos de Latossolos ácricos do norte paulista. Scientia Agricola, v.51, p.321-326, 1994.

ALLEONI, L.R.F.; CAMARGO, O.A. Óxidos de ferro e de alumínio e a mineralogiada fração argila deferrificada de Latossolos ácricos. Scientia Agricola, v.52, p. 409-415, 1995.

ARAÚJO, M.A.; TORMENA, C.A.; INOUE, T.T.; COSTA. A.C.S. Efeitos da escarificação na qualidade física de um Latossolo Vermelho Distroférrico após treze anos de semeadura direta. Revista Brasileira de Ciência do Solo, v. 28, p. 495-504, 2004.

ARRUDA, F.B.; ZULLO JR, J.OLIVEIRA, J.B Parâmetros de solo para cálculo da água disponível com base na textura dos solo. Revista Brasileira de Ciência do Solo, v. 11, p.11$15,1987$.

AZEVEDO, A.C.; BONUMÁ, A.S. Partículas coloidais, dispersão e agregação em Latossolos. Ciência Rural, v.34, p.609-617, 2004.

BENNEMA, J.; LEMOS, R.C.; VETTORI, L. Latosols in Brazil. Proc. $3^{\circ}$ Inter-african soils conference. Dalaba. 1959

BRADY, N. C. Natureza e propriedades dos solos. 5. ed. São Paulo: F. Bastos, 1979. 647 p.

BRIZA. C.D.; FERNANDES JÚNIOR, J.R.; OLIVEIRA, M.A.S. Solos e Ambientes de Produção para cana-de-açúcar na região de Itapira-SP. Trabalhos de conclusão do curso de técnico agrícola com ênfase na cadeia produtiva da cana-de-açúcar. 2009. p. 145-155.

BRUNINI, O. Ambientes climáticos e exploração agrícola da cana-de-açúcar. In: DINARDOMIRANDA, L.L.; VASCONCELOS, A.C.M.; LANDELL, M.G.A. Cana-de-Açúcar, Instituto Agronômico. Campinas. $1^{\text {a }}$ Reimpressão. 2010. p. 205-218.

BRUNINI, O. Sistema de monitoramento e avaliação de riscos climáticos e agrometeorológicos. Campinas, 2005. Software- Linguagem Basic Sistema-Windows/Linux.

CAMPOS, P.M.; LACERDA, M.P.C.; SILVA, C.L.; SÁ, M.A.C; SOUSA, D.M.G. Drenagem interna como fator de diferenciação de Latossolos do Distrito Federal. Pesquisa Agropecuária Brasileira, v.45, p.306-314, 2010.

CARLESSO, R. Absorção de água pelas plantas: Água disponível versus extraível e a produtividade das culturas, revisão. Ciência Rural, v.25, p.183-188, 1995.

CAVALCANTE, E.P.; PRADO, H. Ambientes de Produção de cana-de-açúcar de Latossolos da região de Araxá-MG. Nucleus, v.7, p. 115-124, 2010. 
CEDDIA, M.B.; ANJOS, L.H.C.; LIMA, E.; RAVELLI NETO, A.; SILVA, L.A. Sistemas de colheita da cana-de-açúcar e alterações nas propriedades físicas de um solo Podzólico Amarelo no estado do Espírito Santo. Pesquisa Agropecuária Brasileira, v.34, p. 14671473, 1999.

CENTURION, J.F. ANDRIOLI, I. Regime hídrico de alguns solos de Jaboticabal. Revista Brasileira de Ciência do Solo, v.24, p. 701-709, 2000.

CHAVEIRO, E. O cerrado em disputa: sentidos culturais e práticas sociais contemporâneas. In: ALMEIDA, M.G. et al. (Orgs.) Geografia e cultura: os lugares da vida e a vida dos lugares. Goiânia: Vieira, 2008. p. 75- 97.

CHAVES, J. B. P.; SILVA, C. A. B.; SILVA, F. C.; CESAR, M. A. A. Produção, qualidade e mercado de açúcar mascavo, melado e rapadura, no Brasil. In: SILVA, F. C. DA; CESAR, M. A.A.; SILVA, C. A. B. (Eds.). Pequenas indústrias rurais de cana-de-açúcar: melado, rapadura e açúcar mascavo. Brasília: Embrapa Informação Tecnológica, 2003, p. 11-20.

CONAB - COMPANHIA NACIONAL DE ABASTECIMENTO. Acompanhamento da safra brasileira de cana-de-açúcar, safra 2016/2017. Primeiro levantamento. Brasília: CONAB, 2016. Disponível em: <http://www.conab.gov.br/conteudos.php?a=1253\&t=2>.

COOPER, M.; VIDAL-TORRADO, P. Caracterização morfológica, micromorfológica e físico-hídrica de solos com horizonte B nítico. Revista Brasileira de Ciência do Solo, v.29. p. 581-595, 2005.

CORREIA, J.R.; REATTO, A.; SPERA, S.T. Solos e suas relações com o uso e manejo. In: SOUSA, D.M.G.de; LOBATO, E. Cerrado Correção do solo e adubação. Empresa Brasileira de Pesquisa Agropecuária. Embrapa Cerrados. Planaltina, 2002, p. 43.

COSTA, A.; AlBuQUERQUE, J.A.; COSTA, A.; PÉRTILE, P.; SILVA, F.R. Water retention and availability in soils of the state of Santa Catarina - Brazil: Effect of textural classes, soil classes and lithology. Revista Brasileira de Ciência do Solo, v. 37, p. 1535$1548,2013$.

DALRI, A.B.; CRUZ, R.L. Produtividade da cana-de-açúcar fertirrigada com N e K via gotejamento subsuperficial. Engenharia Agrícola, v.28, p. 516-524, 2008.

DEMATTÊ, J.L.I.; DEMATTÊ, J.A.M. Ambientes de Produção como estratégia de manejo na cana-de-açúcar. Informações Agronômicas, nº 127, Piracicaba, 2009.

DIAS, F.L.F.; MAZZA, J.A.; MATSUOKA, S.; PERECIN, D.; MAULE, R.F. Produtividade da cana-de-açúcar em relação a clima e solos da região noroeste do estado de São Paulo. Revista Brasileira de Ciência do Solo, v. 23, p. 627-634, 1999.

EMBRAPA, Centro Nacional de Pesquisa de Solo (Rio de Janeiro, RJ). Sistema Brasileiro de Classificação de Solos. Rio de Janeiro, 1999, 412p. 
EMBRAPA - EMPRESA BRASILEIRA DE PESQUISA E AGROPECUÁRIA (EMBRAPA). Sistema Brasileiro de Classificação de Solos. $3^{\mathrm{a}}$. ed. Brasília, 2013. 353p.

FABIAN, A.J.; OTTONI FILHO, T.B. Determinação de capacidade de campo in situ ou através de equações de regressão. Pesquisa Agropecuária Brasileira, v.35, p.1029-1036, 2000 .

FAO. Perspectivas Agrícolas no Brasil: desafios da agricultura brasileira 2015-2024, 2015, $54 \mathrm{p}$.

FERREIRA, M.M.; MARCOS, Z.Z. Estimativa da capacidade de campo de Latossolo Roxo distrófico e Regossolo através do ponto de inflexão da curva característica de umidade. Ciência e Prática, Lavras, v.7, p. 96-101, 1983.

FERREIRA, I.C.de.M.; COELHO, R.M.; TORRES, R.B.; BERNACCI, L.C. Solos e vegetação nativa renascente no município de Campinas. Pesquisa Agropecuária Brasileira, v. 42, p.1319-1327, 2007.

FIGUEIREDO, P. Breve história da cana-de-açúcar e do papel do Instituto Agronômico no seu estabelecimento no Brasil. In: DINARDO-MIRANDA, L.L.; VASCONCELOS, A.C.M.; LANDELL, M.G.A. Cana-de-Açúcar, Instituto Agronômico. Campinas. $1^{a}$ Reimpressão. 2010. p. 31-44.

FREITAS JÚNIOR, E.; SILVA, E. M. da. Uso da centrífuga para determinação da curva de retenção de água do solo, em uma única operação. Pesquisa Agropecuária Brasileira, v. 19, p. 1423-1428, 1984.

GOEDERT, W. J. Uso e manejo dos recursos naturais do Cerrado: solo e clima. In: SIMPÓSIO SOBRE O CERRADO, n.5, 1980, Brasília. Cerrado: uso e manejo. Anais... Brasília: Editerra, 1980. p. 475-498.

GONZAGA, G.A. Avaliação do crescimento inicial da cana-de-açúcar, variedade RB867515, sob efeito de bactérias endofíticas. Universidade Federal de Alagoas. Centro de Ciências Agrárias, Rio Largo, 2012, 53f. Dissertação de Mestrado.

GROSS, R.R.; IZAGUIRRE, Y.P.; LIRANZA, N.B.; SUÁREZ, H.J.; ISAAC, M.T.; CARABALlOSO, V.; LÓPEZ, L.V. Contribución de las localidades de Prueba en estudios multiambientales de caña de azúcar. Cultivos Tropicales, v. 34, p. 38-44, 2013.

HILLEL, D. Environmental Soil Physics. Academic New York Press, 1998.

JOAQUIM, A.C; DONZELLI, J.L; QUADROS, A.C; SARTO, L.F. Potencial de produção de cana-de-açúcar. In: Seminário de Tecnologia Agronômica. Centro de Tecnologia Coopersucar. Piracicaba. 1997, Anais... Piracicaba, 1997, p. 68-76.

KLEIN, V.A.; LIBARDI, P.L. Faixa de umidade menos limitante ao crescimento vegetal e sua relação com a densidade do solo ao longo de um perfil de um Latossolo Roxo. Ciência Rural, v. 30, p. 959-964, 2000. 
KLEIN, V. A.; REICHERT, J.M.; REINERT. D.J. Água disponível em um Latossolo Vermelho argiloso e murcha fisiológica de culturas. Revista Brasileira de Engenharia Agrícola e Ambiental, v. 10, p. 646-650, 2006.

KLINK, C.A.; MACHADO. R.B. A conservação do Cerrado brasileiro. Megadiversidade, Belo Horizonte, MG, v. 1, p. 147-156, 2005.

KLUTE, A. Water retention: Laboratory methods. In: KLUTE, A., ed. Methods of soil analysis, Part1: Physical and mineralogical methods, 2ed. Madison, American Society of Agronomy, 1986. p. 635-662.

KLUTHCOUSKI, J.; STONE, L. F.; ADAIR, H. Integração lavoura-pecuária. Santo Antônio de Goiás: Embrapa Arroz e Feijão, 2003. 570 p.

KOHLHEPP, G. Análise da situação da produção de etanol e biodiesel no Brasil. Estudos Avançados, v. 24, p. 223-253, 2010.

KOOREVAAR, P.; MENELIK, G.; DIRKSEN, C. Elements of soil physics. Developments in Soil Science. Elsevier, Amsterdam, v. 13, 1983.

LANDELL, M.G.A.; XAVIER, M.A.; ANJOS, I.A.; VASCONCELOS, A.C.M.; PINTO, L.R.; CRESTE, L. Desenvolvimento e critérios de manejo de variedades. In: RIPOLI, T.C.C.; RIPOLI, M.L.C.; CASAGRANDI, D.V.; IDE, B.Y. Plantio de Cana-de-Açúcar o Estado da Arte, 2006.

LANDELL, M.G.A.; PRADO, H.; VASCONCELOS, A.C.M.; PERECIN, D.; ROSSETTO, R.; BIDÓIA, M.A.P.; SILVA, M.A.; XAVIER, M.A. Oxisol subsurface chemical attributes related to sugarcane productivity. Scientia Agricola, v. 60, p. 741-745, 2003.

LARCHER, W. Ecofisiologia vegetal. São Carlos, SP: RiMa, 2004. 531p.

LEITE, M.H.S.; COUTO, E.G.; AMORIM, R.S.S.; COSTA, E.L.; MARASCHIN, L. Perdas de solo e nutrientes num Latossolo Vermelho-Amarelo Ácrico típico, com diferentes sistemas de preparo e sob chuva natural. Revista Brasileira de Ciência do Solo, v. 33, p. 689-699, 2009.

LEPSCH, I.G. O Sistema Brasileiro de Classificação de Solos (SIBCS). In: LEPSCH, I.G. 19 Lições de Pedologia. Oficina de textos, São Paulo, 2011. p.310-340.

LOPES, A.S.; COX, F.R. A survey of the fertility status of surface soils under "Cerrado" vegetation in Brazil. Soil Science Society of America Journal, Madison, v. 41, p. 742-747, 1977.

LOPES, A.S.; GUILHERME, L.A.G. Solos sob Cerrado. Manejo da fertilidade para a produção agropecuária. ASSOCIAÇÃO NACIONAL PARA DIFUSÃO DE ADUBOS E CORRETIVOS AGRÍCOLAS, ANDA, Boletim técnico nº 5, São Paulo, p. 1-56, 1994.

MATOS, P. F.; PESSÔA, V. L. S. A apropriação do cerrado pelo agronegócio e os novos usos do território. Revista de Geografia Agrária, v. 9, p. 6-26, 2014. 
MAULE, R. F; MAZZA, J. A.; MARTHA JR, G. B. Produtividade agrícola de cultivares de cana-de-açúcar em diferentes solos e épocas de colheita. Scientia Agricola, v. 58, p. 295-301, 2001.

MEDEIROS, J.S.; OLIVEIRA, F.H.T.; ARRUDA, J.A.; VIEIRA, M.S.; FERREIRA, M.P.F. Fontes eficiência de extratores de potássio disponível em solos do estado da Paraíba com graus de desenvolvimento pedogenético diferentes. Revista Brasileira de Ciência do Solo, v. 34, p. 183-194, 2010.

MELLO, C.R. de; OLIVEIRA, G.C. de; FERREIRA, D.F.; LIMA, J.M.de. Predição da porosidade drenável e disponibilidade de água para Cambissolos da microrregião Campos das Vertentes, MG. Pesquisa Agropecuária Brasileira, v. 37, p.1319-1324, 2002a.

MELLO, C.R. de; OLIVEIRA, G.C. de; RESCK, D.V.S.; LIMA, J.M.; DIAS JUNIOR, M.S. Estimativa da capacidade de campo baseada no ponto de inflexão da curva característica. Revista de Ciência e Agrometeorologia. Lavras, v. 26, p. 836-841, 2002 b.

MELLO, C.R.; OLIVEIRA, G.C.; FERREIRA, D.F.; LIMA, J.M.; LOPES, D. Modelos para determinação dos parâmetros da equação de van Genutchen para um Cambissolo. Revista Brasileira de Engenharia Agrícola e Ambiental, v.9, p.23-29, 2005.

MESQUITA, M.A.M.; NAVES, R.V.; SOUZA, E.R.B.; BERNARDES, T.G.; SILVA, L.B. Caracterização de ambientes com alta ocorrência natural de Araticum (Annona crassiflora Mart.) no estado de Goiás. Revista Brasileira de Fruticultura, v. 29, p. 15-19, 2007.

MIELNICZUK, J. Matéria orgânica e sustentabilidade de sistemas agrícolas. In: SANTOS, G. A.; SILVA, L. S.; CANEllaS, L. P.; CAMARGO, F. A. O. Fundamentos da matéria orgânica do solo: ecossistemas tropicais e subtropicais. 2 ed. Porto Alegre: Metrópole, 2008. p.1-18.

MINISTÉRIO DA AGRICULTURA. Levantamento de recomendação dos solos do estado de São Paulo. Boletim do Serviço Nacional de Pesquisas Agronômicas. 1960, 634p.

MIRANDA, J. R. História da cana-de-açúcar. Campinas: Komedi, 2008. 167p.

NASCIMENTO, P.S.; BASSOI, L.H.; PAZ, V.P.S.; VAZ, C.M.P.; NAIME, J.M.; MANIERI, J.M. J.M. Estudo comparativo de métodos para determinação da curva de retenção de água no solo. Revista Irriga, v. 15, p. 193-207, 2010.

NOVACANA. Variedades RB de cana respondem por $65 \%$ da área cultivada no Brasil. Disponível em: https://www.novacana.com/n/cana/variedades/variedades-rb-cana-areacultivada-230915. 2015.

NUNES JUNIOR, D.; PINTO, R.S.A.; TRENTO, F.E.; ELIAS, A.I. Indicadores agrícolas do setor canavieiro, safra 2003/2004. Ribeirão Preto: Idea, 2005. 111p.

OLIVEIRA, L..F.C.; CASTRO, M.L.L.; RODRIGUES, C.; BORGES, J.D. Isotermas de sorção de metais pesados em solos do cerrado de Goiás. Revista Brasileira de Engenharia Agrícola e Ambiental. v. 4, p. 776-782, 2010. 
OLIVEIRA, J.B. Pedologia Aplicada, 2ª edição, Piracicaba, FEALQ, 2005, 574p.

OLIVEIRA, J.B. de; JACOMINE, P.K.T.; CAMARGO, M.N. Classes gerais de solos do Brasil: guia auxiliar para seu reconhecimento. Jaboticabal, FUNEP, 1992. 210p.

OLIVEIRA, J.B. de; PRADO, H. do. Levantamento pedológico semidetalhado do estado de São Paulo: quadrícula de Ribeirão Preto. II. Memorial descritivo. Campinas: Instituto Agronômico, 1987. 133p. (Boletim Científico, 7).

OMETTO, J. C. Parâmetros meteorológicos e a cultura da cana-de-açúcar. Piracicaba: ESALQ, 1980.17p.

PÁDUA JÚNIOR, A.L.; PRADO, H.; MACHADO, B.A.; PETRI, H.D. Influência do caráter plíntico no desenvolvimento da cana-de-açúcar. In: XXXI Congresso Brasileiro de Ciência do Solo, 2007, Gramado, Anais... Gramado, 2007.

PAPA, R.A.; LACERDA, M.P.C.; CAMPOS, P.M.; GOEDERT, W.J.; RAMOS, M.L.G.; KATO, E. Qualidade de Latossolos Vermelhos e Vermelho-Amarelos sob vegetação nativa de Cerrado. Pesquisa Agropecuária Tropical, v. 41, p. 564-571, 2011.

PINCELLI, R.P. Tolerância à deficiência hídrica em cultivares de cana-de-açúcar avaliada por meio de variáveis morfofisiológicas. Botucatu: Universidade Estadual de São Paulo, 2010. 65p. Dissertação Mestrado.

PISSARRA, T.C.T.; POLITANO, W.; FERRAUDO, A.S. Avaliação de características morfométricas na relação solo-superfície da bacia hidrográfica do córrego Rico, Jaboticabal. Revista Brasileira de Ciência do Solo, v. 28, p. 297-305, 2004.

PRADO, H. Pedologia Fácil. Aplicações. $3^{\text {a }}$ ed. Piracicaba, 2011, 118p.

PRADO, H.; PADUA JR, A.L.; GARCIA, J.C.; MORAES, J.F.de; CARVALHO, J.P.; DONZELI, P.L. Solos e Ambientes de Produção. In: DINARDO-MIRANDA, L.L.; VASCONCELOS, A.C.M.; LANDELL, M.G.A. Cana-de-Açúcar, Instituto Agronômico. Campinas, 2010. p.179-204.

REICHARDT, K. Capacidade de campo. Revista Brasileira de Ciência do Solo, v.12, p. 211-216, 1988.

REICHARDT, K.; TIMM, L.C. Solo, planta e atmosfera: conceitos, processos e aplicações. 2. ed. Barueri, SP. Manole, 2008. v.1, 480p.

RIDESA Rede Interuniversitária para o Desenvolvimento do Setor Sucroalcooleiro. Catálogo nacional de variedades "RB” de cana-de-acúcar. Curitiba, 2010. 136 p.

RODOLFO JUNIOR, F. Caracterização de variedades de cana-soca sob diferentes regimes hídricos no Cerrado. Brasília: Universidade de Brasília, 2015. 120p. Tese Doutorado. 
ROSSETTO, R.; VITTI, A.C.; GAVA, G.J.C.; MELLIS, E.V.; VARGAS, V.P.; CANTARELLA, H.; PRADO, H.; DIAS, F.L.F.; LANDELL, M.G.A.; BRANCALIÃO, S.R.; GARCIA, J.C. Cana-de-Açúcar Cultivo com Sustentabilidade. Informações Agronômicas, $n^{\circ}$ 142, INPI - International Plant Nutrition Institute, 2013.

RUIZ, H.A.; FERREIRA, G.B.; PEREIRA, J.B.M. Estimativa da capacidade de campo de Latossolos e Neossolos Quartzarênicos pela determinação do equivalente de umidade. Revista Brasileira de Ciência do Solo, v. 27, p. 389-393, 2003.

SANTOS, D.S.; LEMOS, R.C.; SANTOS, H.G.; KER, J.C.; ANJOS, L.H.C.; SHIMIZU, S.H. Manual de descrição e coleta de solo no campo. $6^{\text {a }}$ ed. Revisada e ampliada, Viçosa, MG, Sociedade Brasileira de Ciência do Solo, 2013. 100p.

SEVERIANO, E.C.; OLIVEIRA, G.C.; DIAS JÚNIOR, M.S.; CASTRO, M.B.; OLIVEIRA, L.F.C.; COSTA, K.A.P. Compactação de solos cultivados com cana-de-açúcar: I -modelagem e quantificação da compactação adicional após as operações de colheita. Engenharia Agrícola, v. 30, p. 404-413, 2010.

SILVA, E.F.; AMARAL, F.C.S. Culturas semiperenes e anuais componentes da base de dados. In: AMARAL, F.C.S. SIBCTI - Sistema Brasileiro de Classificação de Terras para a Irrigação. Enfoque na região Semiárida. Convênio CODEVASP/EMBRAPA. 2. ed. Embrapa Solos, Rio de Janeiro, 2011, p. 115-116.

SYKES, D.J. Reconsideração do conceito da umidade de murchamento permanente. Turrialba, v.19, p.525-530, 1969.

TAIZ, L; ZEIGER, E. Fisiologia vegetal. Porto Alegre: Artmed, 2009, 843 p.

TOMASELLA, J.; HODNETT, M.G. Estimating unsaturated hydraulic condutivity of Brazilian soils using soil-water retention data. Soil Science, Baltimore, v. 162, p. 703-712, 1997.

TORMENA, C.A.; SILVA, A.P da; GONÇALVES, A.C.A. \& FOLEGATTI, M.V. Intervalo ótimo de potencial da água no solo. Um conceito para avaliação da qualidade física do solo e manejo da água na agricultura irrigada. Revista Brasileira de Engenharia Agrícola e Ambiental, v.3, p. 286-292, 1999.

TORRES, L.C.; BARROS, K.R.M.; LIMA, H.V. Alterações na qualidade física de um Latossolo Amarelo sob pastagem. Acta Amazônica. v. 44, p. 419 - 426, 2014.

UEHARA, G. Acric properties and their significance to soil classification. In: INTERNATIONAL SOIL CLASSIFICATION WORKSHOP, 8, Rio de Janeiro, 1986. Proceedings. Rio de Janeiro: EMBRAPA/ SNLCS, 1988. p.19-22.

VAN GENUCHTEN, M.T. A closed form equation for predicting the hydraulic conductivity of unsaturated soils. Soil Science Society of America Journal, Madison, v. 44, p. 892-898, 1980.

VAN LIER, Q.J. Disponibilidade de água às plantas. In: JONG van LIER, Q. Física do Solo. Sociedade Brasileira de Ciência do Solo. Viçosa, Cap. VIII, p. 283-298, 2010. 
VASCONCELOS, A.C.M. Dinâmica do Desenvolvimento radicular de cana-de-açúcar. In: VASCONCELOS, A.C.M.; MIRANDA, L.D. Dinâmica do desenvolvimento radicular da cana-de-açúcar e implicações no controle de nematoides. 2. ed. Campinas. Editora, 2011. p. 10-43.

VASCONCELOS, A.C.M de; CASAGRANDE, A.A. Fisiologia do Sistema Radicular. In: DINARDO-MIRANDA, L.L.; VASCONCELOS, A.C.M.; LANDELL, M.G.A. Cana-deAçúcar. Instituto Agronômico de Campinas: Campinas, 2010. p. 79-97.

VEIHMEYER, F. J.; HENDRICKSON, A. H. The moisture equivalent as a measure of the field capacity of soil. Soil Science, v.32, p.181-193, 1931.

VEIHMEYER, V.J., HENDRICKSON, A.H. Methods of measuring field capacity and wilting percentage of soils. Soil Science, Baltimore, v.68, p.75-94, 1949.

VITTI, A.C.; PRADO, H. Produtividade da cana-de-açúcar em função do ambiente e disponibilidade hídrica. Pesquisa \& Tecnologia, v. 9, n. 2, 2012.

WOSTEN, J.H.M.; SCHUREN, C.H.J.E.; BOUMA, J.; STEIN, A. Functional sensitivity analysis of four methods to generate soil hydraulic functions. Soil Science Society of America Journal, Madison, v. 55, p. 832-836, 1990. 
II. CAPÍTULO 1

FATORES DE PRODUÇÃO DA CANA-DE-AÇÚCAR EM SISTEMA CONVENCIONAL E ORGÂNICO EM LATOSSOLOS FÉRRICOS NA REGIÃO DE GOIATUBA, GO 


\title{
II. CAPITULO 1- FATORES DE PRODUÇÃO DA CANA-DE-AÇÚCAR EM SISTEMA CONVENCIONAL E ORGÂNICO EM LATOSSOLOS FÉRRICOS NA REGIÃO DE GOIATUBA, GO.
}

\begin{abstract}
RESUMO
A produtividade da cana-de-açúcar é influenciada por vários fatores, dentre eles, pode-se destacar o sistema de cultivo, classe de solo, volume de precipitação pluviométrica e sua distribuição durante o ciclo da cultura, época de colheita e número de cortes. Com o objetivo de avaliar o efeito destes fatores na produtividade da cana-de- açúcar na Usina Goiasa, Goiatuba, Sul de GO, foi realizado este trabalho, utilizando o banco de dados da Usina Goiasa. Foram selecionadas as variáveis: produtividade do talhão, sistema de cultivo (convencional e orgânico) em diferentes classes de solos, precipitação pluviométrica acumulada no intervalo das colheitas, época de colheita, considerando o período de quatro cortes da cultura, ao longo dos anos 2008 e 2015. As classes de solos foram agrupadas quanto à caracterização pedológica, propriedades químicas e associadas aos sistemas de cultivo, sendo os solos definidos como: Latossolos Distroférricos com soma de bases no horizonte Bw igual ou superior a 1,0 $\mathrm{cmol}_{\mathrm{C}} \mathrm{dm}^{-3}$; Latossolos Distroférricos com soma de bases no horizonte $\mathrm{Bw}$ inferior a 1,0 $\mathrm{cmol}_{\mathrm{cdm}}{ }^{-3}$; Latossolos Acriférricos, com soma de bases no horizonte $\mathrm{Bw}$ inferior a $1,0 \mathrm{cmol}_{\mathrm{C}} \mathrm{dm}^{-3}$, sendo todos os solos de textura muito argilosa. Estes solos predominam na usina estudada, sendo tais classes consideradas representativas. Os dados foram analisados estatisticamente mediante correlação de Pearson e modelos de regressão linear múltipla com o uso de variáveis Dummy, com o emprego do programa estatístico SPSS. A precipitação pluviométrica acumulada no período relativo a cada época de colheita mostraram correlações significativas no sistema convencional e não significativas no sistema orgânico em função das épocas de colheita nos dois sistemas de cultivo. O Latossolo com maior soma de bases em subsuperfície (LVdf.1.1) proporcionou a maior produtividade da cana-de-açúcar entre as classes de solos no sistema orgânico. O modelo de regressão linear múltipla, apresentou a variável cortes (primeiro ao quarto) como significativa para estimar a variável produtividade da cultura. A produtividade da cana-de-açúcar em diferentes classes de solos, épocas de colheita, cortes, precipitação pluviométrica e sistemas de cultivo foi explicada por meio do modelo preditivo com $\mathrm{R}^{2}$ de 0,40 na região estudada.
\end{abstract}

Palavras-chave: Ambientes de produção, sistema de produção, propriedades químicas dos solos. 


\title{
II. CHAPTER 1 - PRODUCTION FACTORS OF SUGARCANE IN CONVENTIONAL AND ORGANIC SYSTEM IN FERRIC LATOSOLS IN THE REGION OF GOIATUBA, GO
}

\begin{abstract}
The productivity of sugarcane is influenced by several factors, among them we can highlight the cultivation system, the soil class, the rainfall volume and its distribution during the crop cycle, the harvest times and the number of cuts. With the aim of evaluating the effect of these factors in the productivity of the sugarcane in the Usina Goiasa, Goiatuba, in southern of Goiás state, this study was realized, using the database of Usina Goiasa. The following variables were selected: productivity of the plot, cultivation system (conventional and organic) in different soils classes, accumulated rainfall during the harvest interval, harvest times, considering the period of four cuts of the culture, throughout the years of 2008 and 2015. The classes of soils were grouped considering the pedological characterization, chemical properties, and associated to the cultivation system, defining the soils as: Dystroferric Latosols with sum of bases in the horizon Bw the same as or exceeding the 1,0 $\mathrm{cmol}_{c} \mathrm{dm}^{-3}$, Dystroferric Latosols with sum of bases in the horizon Bw below 1,0 $\mathrm{cmol}_{\mathrm{c}} \mathrm{dm}^{-3}$, Acriferric Latosols with sum of bases in the Bw horizon below 1,0 $\mathrm{cmol}_{c} \mathrm{dm}^{-3}$, with all the soils with a very clayey texture. These soils predominate in the studied plant, so these classes are considered as representative. The data were statistically analyzed using Pearson's correlation and the multiple linear regression models with the use of Dummy variables, and with the use of the statistical programme SPSS. The accumulated rainfall in the period related to each harvest times showed significant correlations in the conventional system, and not significant in the organic system in function of the harvest times in both cultivation systems. The Latosol with larger sum of bases in subsurface (LVdf.1.1) provided the largest sugarcane productivity between the classes of soils in the organic system. The multiple linear regression model presented the cuts variable (first to fourth) as significant to estimate the culture productivity variable. The sugarcane productivity in different classes of soils, harvest times, cuts, rainfall and cultivation systems was explained by the predictive model with $\mathrm{R}^{2}$ of 0.40 in the studied region.
\end{abstract}

Key words: Production environments, production system, chemical properties of soils. 


\section{II.1. INTRODUÇÃO}

A região Centro-Oeste Brasileira ocupa posição de destaque na produção de cana-deaçúcar. Em especial o Estado de Goiás, responsável por 10,3 \% da área cultivada e 10,7\% da produção nacional, superado somente pelo estado de São Paulo (CONAB, 2016).

A cultura da cana-de-açúcar, em função do seu extenso sistema radicular, é uma cultura altamente dependente das propriedades químicas e atributos físico-hídricos de subsuperfície dos solos, afetando o crescimento, desenvolvimento e longevidade do canavial (Landell et al., 2003; Vasconcelos e Casagrande, 2010).

Avaliações das potencialidades e limitações das diferentes classes de solos associadas ao clima, sistema de cultivo e seus efeitos para as culturas são escassas. As características pedogenéticas dos solos, geralmente, não são utilizadas como parâmetros na tomada de decisão para o manejo das culturas. Entretanto, alguns trabalhos, como o de Joaquim et al. (1997); Landell et al. (2003); Medeiros et al. (2010); Prado et al. (2010) entre outros, consideram essas variáveis como fatores importantes na distribuição do sistema radicular e consequentemente na produção vegetal, caracterizando-se, assim, como importante critério na seleção de variedades das culturas.

$\mathrm{O}$ estudo de somente alguns atributos dos solos relacionados à produtividade das culturas são mais frequentes. Pode-se citar o trabalho Cunha et al. (2000) que relacionaram o potencial produtivo da seringueira com a disponibilidade hídrica e proporção de microporos no horizonte de subsuperfície em solos com horizonte Bt; e Santos et al. (2009), que avaliaram o caráter químico em três classes de solos (Latossolo, Neossolo e Luvissolo) na produção de sorgo. Já Dalchiavon et al. (2013) definiram o teor de matéria orgânica como a variável responsável pelas diferenças da produtividade da cana-de-açúcar em Argissolo Vermelho Eutrófico.

Trabalhos de avaliação das relações entre características físico-hídricas e disponibilidade de água dos solos e a produtividade das culturas são, ainda, mais raros, sendo estas características dos solos extremamente importantes como fatores de produção da canade-açúcar (Dias et al., 1999). Com este enfoque, Ferreira et al. (2007) estudaram o surgimento da vegetação nativa em Campinas, SP, com base na disponibilidade hídrica das classes de solo, onde relacionaram vegetação de Cerrado em áreas de Latossolos em função da baixa disponibilidade de água e o surgimento das matas (Floresta tropical subcaducifólia) em solos com elevada disponibilidade hídrica nos horizontes B textural e B nítico, de acordo com a distinta distribuição de poros entre os horizontes superficiais e subsuperficiais. Já Cooper e 
Vidal-Torrado (2005) estudaram o comportamento físico-hídrico de Nitossolos Vermelhos Eutroférricos típico e latossólico, e verificaram que estrutura em blocos no horizonte B do NVef típico, foi responsável pela maior retenção de água e menor condutividade hidráulica do solo, em função da heterogeneidade do tamanho dos poros no perfil do solo. No entanto, no NVef latossólico, a transição para o horizonte B com características latossólicas diminuiu a retenção e aumentou a condutividade hidráulica, devido a predominância de poros de mesmo tamanho ao longo do perfil do mesmo.

Com relação a cultura da cana-de-açúcar, Gross et al. (2013) compararam diferentes genótipos desta cultura em distintas localidades da região sudeste de Cuba e concluíram que os solos com drenagem excessiva associado ao baixo índice pluviométrico influenciaram negativamente na produtividade da cultura.

No Brasil, Joaquim et al. (1997) foram os pioneiros em explicar a produtividade da cana-de-açúcar cultivada em diferentes classes de solos, propondo um sistema de classificação denominado de ambiente de produção. Em relação aos sistemas de manejo, no sistema orgânico os nutrientes são fornecidos na forma de resíduos orgânicos provenientes da usina. A obtenção de selos de qualidade fornecidos pelas certificadoras nacionais e internacionais coloca esses produtos do setor sucroalcooleiro em nichos de mercado específicos, os quais proporcionam melhor valorização do produto final (Ariedi Junior, 2013).

A época de colheita é uma importante estratégia de manejo adotada pelas usinas de cana-de-açúcar em busca das maiores produtividades. De acordo com Landell e Bressiani (2010), a condição ideal para o manejo da cana-de-açúcar seria associar as elevadas produtividades da cultura obtidas na colheita de outono com os altos teores de sacarose obtidos na colheita de inverno. Entretanto, a cana-de-açúcar tem o seu potencial produtivo reduzido ao longo do período de colheita na região Centro-Sul de outono até a primavera, em função da estação seca e estresse hídrico ao longo do período de colheita.

Landell et al. (2005) sugerem a colheita da cana-de-açúcar na primavera (outubronovembro) para as variedades mais adaptadas em ambientes favoráveis, cultivada em solos de caráter químico eutrófico, com elevada disponibilidade hídrica, devido a menor queda na produtividade durante as demais épocas de colheita. Entretanto, Landell e Bressiani (2010) recomendam a colheita das variedades tardias em ambientes mais favoráveis e as variedades de ciclo precoce os ambientes inferiores.

Por outro lado, Demattê e Demattê (2009) relataram produtividade de $20 \mathrm{Mg} \mathrm{ha}^{-1}$ superior para a cana-de-açúcar, variedade RB72454, cultivada em Argissolo Vermelho 
colhida no outono $\left(98 \mathrm{Mg} \mathrm{ha}^{-1}\right)$ comparada à colheita realizada na primavera $\left(78 \mathrm{Mg} \mathrm{ha}^{-1}\right)$ do município de Quatá, Estado de São Paulo.

Diante deste cenário, este trabalho teve como objetivo avaliar a produtividade da canade-açúcar em áreas de produção da Usina Goiasa, Goiatuba-GO, em relação às principais variáveis que influenciam na produção, possibilitando a geração de modelos preditivos de produtividade de cana-de-açúcar na região estudada. 


\section{II.2. MATERIAL E MÉTODOS}

\section{2.1. Localização da área estudada}

O presente estudo foi realizado na Usina Goiasa, localizada no município de Goiatuba (GO) e com áreas de produção nos munícipios de Goiatuba e Bom Jesus (Figura 4).

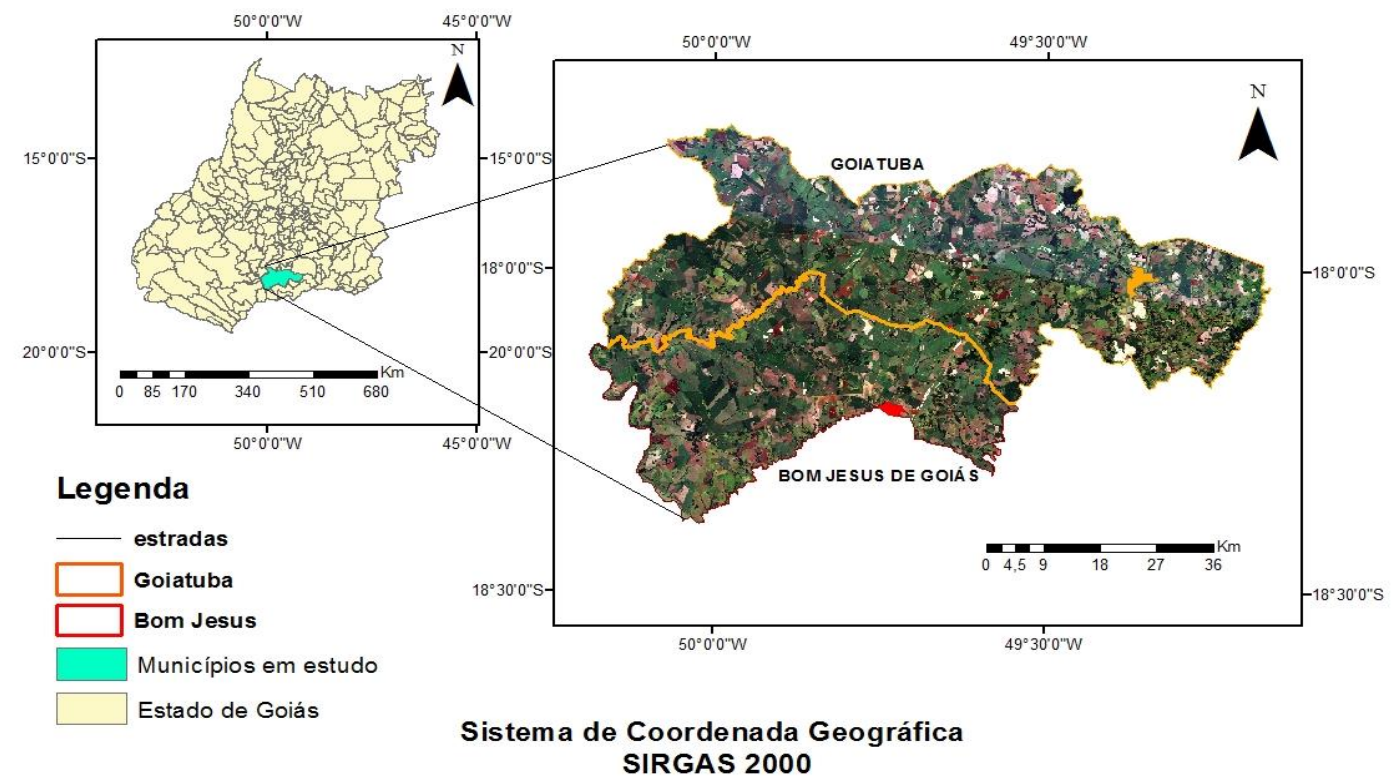

Figura 4. Localização da Usina Goiasa nos municípios de Goiatuba e Bom Jesus, região Sul do Estado de Goiás.

\section{II.2.2. Obtenção dos dados}

Os dados foram obtidos a partir do banco de dados da Usina Goiasa, do período de janeiro de 2008 até o mês de agosto de 2015.

\section{II.2.2.1. Variáveis estudadas}

\section{Produtividade da cana-de-açúcar}

Os dados das produtividades dos talhões foram adquiridos em toneladas de colmos por hectare $(\mathrm{TCH})$ obtidos diariamente pelos profissionais no parque de pesagem dos caminhões na indústria e documentados por meio de relatório de produtividade à equipe técnica da Usina Goiasa.

\section{Sistemas de cultivo e classes de solos}

Os sistemas de cultivo avaliados foram o orgânico e o convencional. Em ambos sistemas é em geral realizada a subsolagem seguida de gradagem pesada para incorporação de calcário dolomítico aplicado na reforma dos canaviais. O manejo da fertilidade do solo da 
lavoura em sistema orgânico utiliza para adubação torta de filtro compostada com cinzas das caldeiras e vinhaça diluída em água na irrigação de salvamento para a rebrota da cana-deaçúcar. No sistema convencional a adubação de plantio é realizada mediante a aplicação de formulações com ureia, fosfato monoamônico e cloreto de potássio. Nas soqueiras são aplicados anualmente, sobre a palhada na superfície do solo, formulações a base de nitrato de amônio e o cloreto de potássio.

Os dados de solos foram obtidos por intermédio de levantamentos pedológicos disponíveis na Usina Goiasa, realizados mediante amostras deformadas coletadas por meio de tradagens nas profundidades de 0-25; 25-50 e 80-100 cm, com determinação das propriedades químicas dos solos (complexo sortivo), sendo o mapa de solos elaborado em escala detalhada (1:20.000). O mapa de solos foi elaborado pelo Centro de Tecnologia Canavieiro (CTC, 2009). Foram selecionados para este estudo os Latossolos Vermelhos de textura muito argilosa, predominantes na Usina, sob sistema de cultivo convencional e orgânico. As classes de solos estudadas foram os Latossolos Vermelhos Distroférricos (LVdf) e Acriférricos (LVwf). O critério para escolha dos talhões foi a presença da mesma classe de solo em pelo menos $75 \%$ da área.

De acordo com a classificação dos solos pelo CTC (2009) a nomenclatura dos Latossolos foi associada a duas numerações, sendo a primeira referente ao grupo textural, onde a textura muito argilosa, é caracterizada pelo número 1 (um), sendo o segundo número correspondente à soma de bases do horizonte subsuperficial; sendo que o número 1 (um) indica soma de bases igual ou superior a $1,0 \mathrm{cmol}_{c} \mathrm{dm}^{-3}$ e o número 4 (quatro) corresponde a soma de bases inferior a $1,0 \mathrm{cmol}_{\mathrm{C}} \mathrm{dm}^{-3}$. A base de dados utilizada apresenta três classes de solos para o sistema de cultivo convencional (enumeradas de 1 a 3 ) e duas classes para o sistema orgânico (classificadas como 4 e 5). A associação do sistema de cultivo com as classes de solo, de acordo com a CTC (2009) foram gerados neste trabalho, conforme demonstra a Tabela 1.

Tabela 1. Classes de solos em sistemas de cultivo de cana-de-açúcar da Usina Goiasa, Goiatuba, GO.

\begin{tabular}{ccc}
\hline Classes de Solos & Sistemas de Cultivo & Simbologias \\
\hline 1 & & LVdf.1.1 \\
2 & Convencional & LVdf.1.4 \\
3 & & LVwf.1.4 \\
4 & Orgânico & LVdf.1.1 \\
5 & & LVdf.1.4
\end{tabular}




\section{Precipitação pluviométrica acumulada}

De acordo com a classificação de Köppen o clima na região de estudo é classificado como Aw, considerado como tropical úmido, com duas estações bem definidas, úmida no verão com chuvas concentradas nos meses de dezembro a março e seca no inverno. A temperatura média anual é de $23^{\circ} \mathrm{C}$, com índices pluviométricos anuais de $1350 \mathrm{~mm}$ (Climatempo, 2016). Os dados de precipitação pluviométrica acumulada foram obtidos pela média de seis pluviômetros instalados em diferentes localidades na Usina Goiasa. Tais dados foram obtidos diariamente com valores expressos em milímetros ( $\mathrm{mm}$ ) e utilizados nos cálculos de precipitação acumulada durante o período de crescimento da cana-de-açúcar, do plantio ao corte da cana-planta e de corte a corte com relação a cana soca (soqueiras).

\section{Cortes}

A cana é plantada no período de janeiro a abril, sendo a cana planta (primeiro corte) colhida no intervalo de tempo de até 18 meses (cana de um ano e meio), sendo os cortes seguintes (soqueiras) colhidas com aproximadamente 12 meses em relação ao ano anterior. $\mathrm{O}$ número de ciclos da cultura avaliados foi limitado em quatro.

\section{Épocas de colheita}

Durante o ciclo de produção da cultura em cada colheita os cortes foram em três períodos. Os períodos foram classificados conforme descritos em Landell e Bressiani (2010) sendo: período de colheita 1 - de outono (01 de abril a 21 de junho); 2 - inverno de 22 de junho a 21 de setembro e período de colheita 3 de primavera (22 de setembro a 30 de novembro).

A cana-de-açúcar sob o manejo orgânico, de acordo com o banco de dados é colhida na Usina Goiasa no inverno, para obter o maior teor de açúcar acumulado nos colmos, correspondente ao período de colheita 2 e a cultura sob manejo convencional é colhida nos períodos de colheita 1, 2 e 3 (outono, inverno e primavera), respectivamente. Para transformar a variável categórica época de colheita em variável quantitativa os dados foram transformadas para dia Juliano.

\section{II.2.3. Modelo Estatístico}

Todos os dados obtidos foram submetidos a análises de correlação de Pearson e regressão linear múltipla, esta última com variáveis Dummy (Hardy, 1993) para preditores qualitativos, 
utilizando o programa estatístico Statistical Package for the Social Sciences - SPSS, versão 19 (IBM, 2010).

A correlação de Pearson foi realizada individualizando os sistemas de cultivo: 1 . conjunto dos dois sistemas de cultivo; 2. sistema convencional; e 3. sistema orgânico. As variáveis quantitativas foram estabelecidas conforme disponibilidade do banco de dados da Usina Goiasa, e por sua importância em predizer a produtividade da cultura da cana-de-açúcar sendo o volume de precipitação pluviométrica $(\mathrm{mm})$ e o período de colheita, transformada em dia Juliano as variáveis quantitativas com que foram realizadas as correlações com a produtividade.

Para efetuar as análises de regressão linear múltipla, para predição da produtividade da cana-de-açúcar utilizou-se o procedimento Enter, onde são apresentados os valores de significância (valor P), referentes a todos os coeficientes do modelo. Contrário ao que foi realizado nas correlações de Pearson quanto a individualização dos sistemas de cultivo, no modelo de regressão linear, foi gerada uma única equação. No procedimento Enter a primeira ou a última variável classificada pelo procedimento estatístico é adicionada no intercepto (X0) e as demais variáveis são somadas ou subtraídas do X0. A equação de regressão linear múltipla utilizou as variáveis binárias Dummy, para transformar as variáveis qualitativas (categóricas) tais como classes de solos (1 A 5), cortes (1 a 4) e sistemas de cultivo (convencional e orgânico), cujos parâmetros são classificados pelos números 0 ou 1, ou seja: 0 na ausência e 1 na presença da variável avaliada, tal como demonstra a equação 1:

$\mathrm{Y}_{\mathrm{i}}=\beta_{1}+\beta_{2} \mathrm{D}_{2, \mathrm{i}}+\beta_{3} \mathrm{X}_{\mathrm{i}}+\mathrm{U}_{\mathrm{i}}$

(Equação 1)

Sendo que:

$\mathrm{Y}=$ variável dependente;

$\beta=$ coeficientes do modelo;

D = variáveis independentes Dummy;

$\mathrm{X}=$ variáveis independentes quantitativas;

$\mathrm{U}=$ erro (resíduo).

Este procedimento permitiu estimar a significância das seguintes variáveis: sistema convencional-classe de solo um (X1), sistema convencional-classe de solo dois (X2), sistema convencional-classe de solo três (X3), sistema orgânico-classe de solo cinco (X4), precipitação pluviométrica acumulada (X5), produtividade no segundo corte (X6), produtividade no terceiro corte $(\mathrm{X} 7)$, produtividade no quarto corte (X8) e época de colheita (outono, inverno e primavera) (X9). O procedimento Enter incluiu a produtividade do 
primeiro corte da cana-de-açúcar em sistema orgânico na classe de solo quatro (4) como o intercepto (X0).

Para a obtenção dos valores de produtividade da cana-de-açúcar no primeiro corte foi necessário utilizar o valor do intercepto como referência e subtrair das variáveis: (X1) para obtenção da produtividade do primeiro corte no sistema convencional na classe de solos um (LVdf.1.1); (X2) produtividade do primeiro corte no sistema convencional na classe de solos dois (LVdf.1.4); (X3) produtividade do primeiro corte no sistema convencional na classe de solos três (LVwf.1.4) e (X4) produtividade do primeiro corte no sistema orgânico na classe de solos cinco (LVdf.1.4). O efeito das demais variáveis na produtividade da cultura da cana-deaçúcar, tais como: (X5), produtividade no segundo corte (X6), produtividade no terceiro corte (X7), produtividade no quarto corte (X8) e época de colheita (dia Juliano) (X9) foram calculados da mesma maneira conforme relatado acima para obtenção da produtividade da cultura no primeiro ciclo em diferentes sistemas de cultivo e classes de solos.

Foi realizada a análise exploratória para verificar a existência de possíveis valores de exclusão (outliers) por meio dos resíduos padronizados maiores que +3 ou menores que -3 . A análise de variância foi realizada para avaliar a significância do modelo de regressão linear múltipla e o teste $\mathrm{t}$ avaliou a significância estatística dos coeficientes de regressão, estimados para as variáveis independentes, em nível de significância de 5\%. Foram, também, avaliados os quatro pressupostos para a realização regressão linear múltipla (linearidade, independência dos erros, normalidade dos erros e igualdade de variâncias - homocedasticidade), assim como, a existência de multicolinearidade das variáveis. No modelo gerado, a produtividade é a variável dependente e as demais, constituem as variáveis independentes, ou seja: classes de solos nos sistemas de cultivo, precipitação pluviométrica acumulada durante o ciclo do desenvolvimento da cana-de-açúcar, épocas de colheita e número de cortes da cultura.

\section{II.3. RESULTADOS E DISCUSSÃO}

\section{II.3.1. Produtividade média de cana-de-açúcar em diferentes épocas de colheita em sistema convencional e orgânico}

A produtividade da cana-de-açúcar foi obtida pela média aritmética dos dados (n) em diferentes classes de solos em quatro cortes e a avaliação da dispersão estatística foi medida por meio do desvio padrão. Para estimar a produtividade da cultura no sistema convencional foram analisados 169 dados $(n=169)$ e no sistema orgânico $32(n=32)$. O estudo do banco de dados da Usina Goiasa permitiu observar as diferenças de produtividade da cana-de-açucar 
entre os diferentes sistemas de cultivo no período de quatro cortes da cultura. Os dados médios de produtividade da cana-de-açúcar nos sistemas orgânico e convencional nos solos mais representativos da Usina Goiasa, nos quatros cortes da cultura em cada época de colheita nos anos de 2008 a 2015 estão apresentados na tabela 2.

Tabela 2. Média da produtividade da cana-de-açúcar $\left(\mathrm{Mg} \mathrm{ha}^{-1}\right)$ por época de colheita e corte em sistema convencional e orgânico em diferentes classes de solos na Usina Goiasa, Goiatuba, GO .

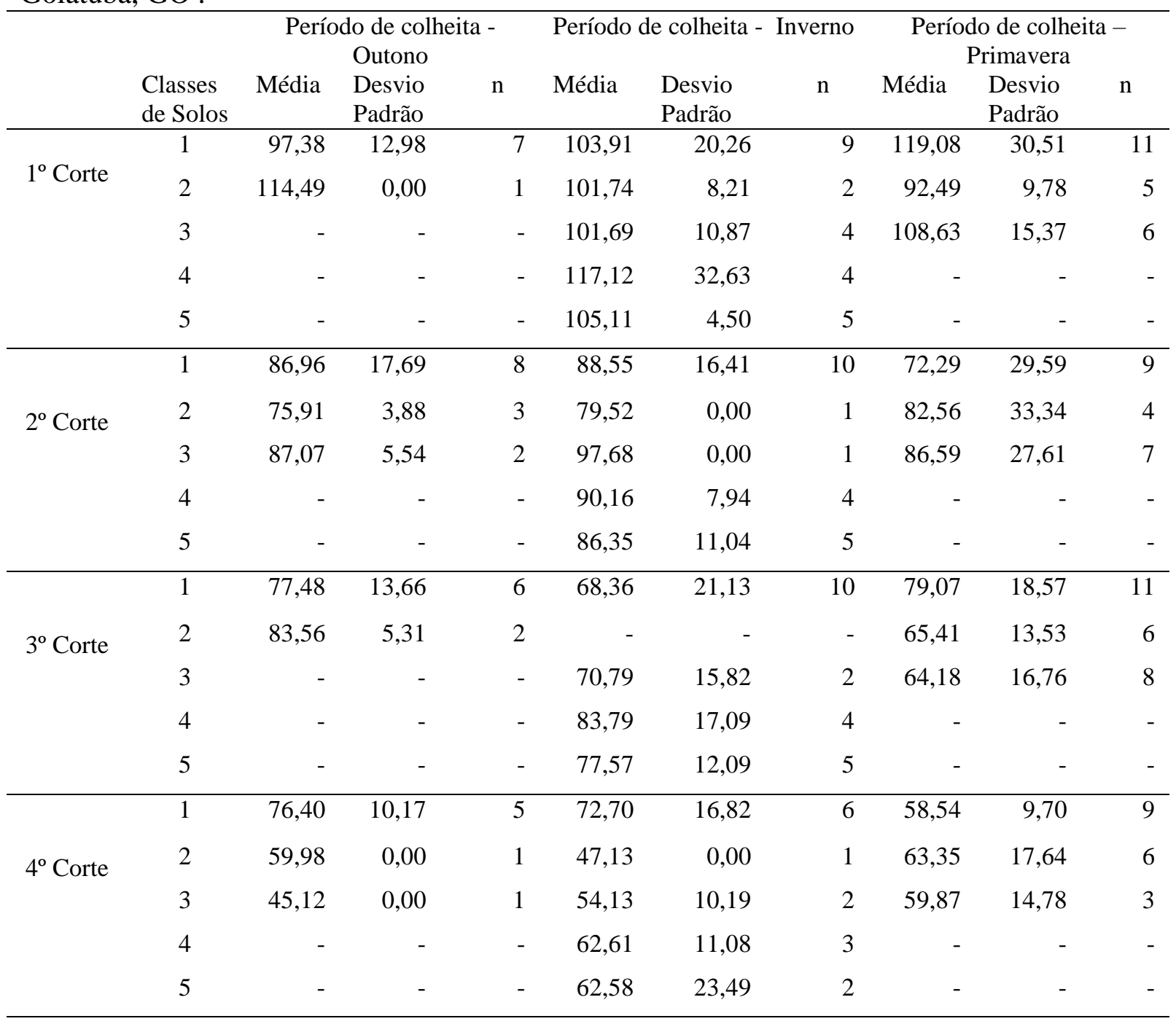

Ao avaliar os valores médios da produtividade da cana-de-açúcar no sistema de cultivo orgânico, o Latossolo distrófico, com maiores teores de soma de bases em profundidade (classe 4) foi o solo que apresentou a maior produtividade na época de colheita de inverno nos três cortes da cultura (Tabela 2) com valores do primeiro corte de $12,01 \mathrm{Mg} \mathrm{ha}^{-1}$; no segundo corte 3,81 e no terceiro corte de $6,22 \mathrm{Mg} \mathrm{ha}^{-1}$ superiores a produtividade da cultura na classe de solos cinco (LVdf.1.4). No quarto corte a produtividade da cana-de-açúcar foi praticamente a mesma entre as classes de solos (Tabela 2). Na mesma linha de pesquisa Landell et al. 
(2003), descreveram a importância do caráter químico de subsuperfície na produtividade da cana-de-açúcar dos Latossolos na região Centro-Sul do Brasil, cultivados em sistema convencional. As áreas orgânicas na Usina Goiasa estão localizadas nas proximidades dos tanques de vinhaça e recebem as maiores quantidades do adubo orgânico o que pode ter otimizado a produtividade da cultura sob o sistema orgânico. Silva et al. (2014) estudaram o efeito da aplicação de vinhaça na cultura da cana-de-açúcar cultivada em Neossolo Quartzarênico no município de Campo Grande, MS, e constataram aumento de produtividade do segundo ao quarto ciclos da cultura, devido ao fornecimento de nutrientes pelo adubo orgânico. De acordo com Paulino et al. (2011) o uso de vinhaça em Latossolo Vermelho textura areia franca, ao longo do tempo, aumentou a produtividade da cana-de-açúcar e a quantidade de raízes no perfil, devido à presença de nutrientes em subsuperfície, no município de Cidade Gaúcha, PR. Já no sistema convencional o comportamento das variedades de canade-açúcar foi distinto nas diferentes classes de solos e épocas de colheita (tabela 2). Provavelmente o baixo número de dados (n) tenha influenciado nos valores de produtividade da cana-de-açúcar (Tabela 2). No primeiro corte, como não houve dados disponíveis de produtividade da cultura em LVwf.1.4 (classe de solo 3) na época de colheita de outono (Tabela 2) a comparação foi realizada entre as classes de solos um e dois, sendo a produtividade da cultura superior em 17,11 $\mathrm{Mg} \mathrm{ha}^{-1}$ no LVdf.1.4 (classe de solo 2), porém com apenas um dado (n) de produtividade nesta classe de solo. Nas épocas de colheita de inverno e primavera a produtividade da cultura da cana-de-açúcar foi crescente nas classes de solos (1 e 3) com acréscimo na produtividade entre as épocas de colheita de $15,17 \mathrm{Mg} \mathrm{ha}^{-1} \mathrm{e}$ $6,94 \mathrm{Mg} \mathrm{ha}^{-1}$ para as classes um e três respectivamente (Tabela 2). Na classe de solo dois (LVdf.1.4) o comportamento produtivo da cultura foi inverso ao obtido no LVdf.1.1 e LVwf.1.4 (classes de solos um e três), com redução na produtividade da cultura de $9,25 \mathrm{Mg}$ $\mathrm{ha}^{-1}$ colhida na primavera em relação à época de inverno (Tabela 2). Ressalta-se que na classe de solos dois o número de dados (n) é inferior ao das classes de solos um e três (Tabela 2) dificultando uma análise consistente dos dados. Segundo Landell et al. (2005) a produtividade da cana-de-açúcar em diferentes épocas de colheita expressa seu maior potencial produtivo no outono, comparado as épocas de inverno e primavera, devido às melhoras condições climáticas da época de colheita. Entretanto, Demattê e Demattê (2009) consideram além da época de colheita o período do plantio como variável importante para estimar a produtividade da cultura da cana-de-açúcar em função da condição climática no qual a cultura estará submetida em cada corte. No segundo corte, a classe de solo três (LVwf.1.4) foi mais produtiva nas três épocas de colheita (outono, inverno e primavera), entretanto, o pequeno 
número de dados no outono e inverno podem ter influenciado os resultados. Porém a colheita de primavera, a cultura cultivada no LVwf.1.4 (classe de solos 3), manteve o elevado potencial produtivo, com 14,30 $\mathrm{Mg} \mathrm{ha}^{-1}$ superior a classe de solo 1 (LVdf.1.1) e 4,03 $\mathrm{Mg} \mathrm{ha}^{-1}$ mais produtiva que o LVdf.1.4 (classe de solo 2). Por outro lado, Landell e Bressiane (2010) recomendam a colheita da cana-de-açúcar em Latossolos ácricos na época de colheita de outono devido à baixa disponibilidade hídrica desses solos para a cultura, ou no inverno, com a necessidade de irrigação complementar para a brotação do ciclo posterior da cultura, em função do baixo índice pluviométrico no período de colheita de inverno.

No terceiro corte, a época de colheita de outono devido à falta de dados na classe de solo três a comparação da produtividade da cana-de-açúcar foi realizada entre as classes de solos um e dois, sendo a classe dois (LVdf.1.4) mais produtiva em 6,08 $\mathrm{Mg} \mathrm{ha}^{-1}$. $\mathrm{Na}$ colheita de inverno a comparação foi somente entre as classes de solos um (LVdf.1.1) e três (LVwf.1.4) com produtividade da cana-de-açúcar superior em 2,43 $\mathrm{Mg} \mathrm{ha}^{-1}$ na classe de solo três. Já na época de colheita de primavera o caráter químico da classe de solo um (LVdf.1.1) contribuiu para a produtividade da cana-de-açúcar com valores de produtividade da cultura superiores aos obtidos nas classes de solos dois (LVdf.1.4) em 13,66 $\mathrm{Mg} \mathrm{ha}^{-1}$ e superiores a classe três (LVwf.1.4) em 14,89 $\mathrm{Mg} \mathrm{ha}^{-1}$. De acordo com Landell et al. (2003) a melhor condição química em subsuperfície favorece a produtividade e a longevidade da cultura da cana-de-açúcar em Latossolos da região Centro-Sul do Brasil.

No quarto corte, a produtividade da cana-de-açúcar na classe de solo um (LVdf.1.1) foi superior nas épocas de colheita de outono e inverno, provavelmente pelo caráter químico favorável em subsuperfície (Tabela 2). Na colheita de outono a produtividade da cana-deaçúcar na classe de solo 1 (LVdf.1.1) foi superior em 16,42 $\mathrm{Mg} \mathrm{ha}^{-1}$ em relação a classe de solo dois (LVdf.1.4) e 31,28 $\mathrm{Mg} \mathrm{ha}^{-1}$ superior comparada a classe de solo três (LVwf.1.4). Já na época de colheita de inverno o LVdf.1.1 (classe de solo 1) proporcionou ambiente favorável para a produtividade da cana-de-açúcar sendo superior em 25,57 $\mathrm{Mg} \mathrm{ha}^{-1}$ comparado a classe de solo dois (LVdf.1.4) e 18,57 $\mathrm{Mg} \mathrm{ha}^{-1}$ superior a classe de solo três (LVwf.1.4). Porém, na colheita de primavera a classe de solos dois (LVdf.1.4) foi superior em 4,81 $\mathrm{Mg} \mathrm{ha}^{-1}$ comparada a classe um (LVdf.1.1) e 3,48 $\mathrm{Mg} \mathrm{ha}^{-1}$ mais produtivo que a classe de solo três (LVwf.1.4). De acordo com Demattê e Demattê (2009) o menor potencial produtivo da cana-de-açúcar em solos ácricos deve-se a sua baixa disponibilidade de água para a cultura. Resultado semelhante foram relatados por Alleoni e Camargo (1994) em Latossolos Vermelhos Ácricos do noroeste do estado de São Paulo. Entretanto, Landell et al. (2003) 
indicaram a baixa soma de bases do horizonte $\mathrm{Bw}$ dos Latossolos ácricos como fator limitante para a produtividade da cana-de-açúcar.

\section{II.3.2. Efeito da época de colheita e da precipitação pluviométrica na produtividade da cana-de-açúcar em diferentes sistemas de cultivo}

Por meio de análises de correlações de Pearson, a produtividade foi correlacionada com as variáveis quantitativas precipitação pluviométrica acumulada durante o ciclo da cultura e a época da colheita em cada sistema de cultivo, e posteriormente foi verificado o efeito em cada corte da cultura, conforme dados expressos na tabela 3. No sistema convencional o valor de $28,40 \%$ foi obtido na correlação entre as variáveis precipitação pluviométrica acumulada e épocas de colheita.

Provavelmente esse valor esteja relacionado ao planejamento de colheita da cultura na Usina Goiasa em sistema convencional, que prioriza o corte da cana-de-açúcar nas três épocas de corte (outono, inverno e primavera), demonstrando o efeito da precipitação pluviométrica ao longo das épocas de colheita o que pode ter mantido níveis variados de disponibilidade hídrica do solo para a cultura. No sistema orgânico, a correlação entre as variáveis precipitação pluviométrica e data do corte obteve o valor de $10,00 \%$, porém, não significativo. A provável causa da baixa correlação entre as variáveis seja o planejamento da colheita da cana-de-açúcar no inverno e o baixo índice de precipitação pluviométrica na região de estudo. De acordo com Climatempo (2016), os dados do índice pluviométrico dos últimos 30 anos nos municípios de Goiatuba e Bom Jesus, a média de precipitação pluviométrica no inverno foi de $58 \mathrm{~mm}$ acumulados durante a estação, fator este que pode ter afetado o valor da correlação entre as variáveis. No conjunto de sistemas de cultivo associados (convencional e orgânico) a correlação foi de 29,90\%, provavelmente este valor esteja relacionado aos dados do sistema convencional, que além de possuir mais dados (n), quando comparados ao sistema orgânico (Tabela 2), contemplam os três períodos de colheita do estudo. Porém, os autores observaram que a resposta da produtividade da cultura em diferentes períodos de colheita está associada a outros fatores como por exemplo à adaptação do genótipo ao ambiente. Por outro lado, a produtividade de colmos por hectare $(\mathrm{TCH})$ da cana-de-açúcar correlacionou-se com a precipitação pluviométrica acumulada nos solos em 16,90\% no sistema convencional. 
Tabela 3. Correlação Pearson entre as variáveis produtividade de cana-de-açúcar (TCH), precipitação pluviométrica acumulada dutante o ciclo da cultura e data do corte nos sistemas de manejo orgânico e convencional com as correlações indivicualizadas para os cortes $1,2,3$ e 4 em cada sistema, Usina Goiasa, Goiatuba, GO

\begin{tabular}{|c|c|c|c|c|c|c|c|c|c|c|c|c|}
\hline \multirow{4}{*}{$\begin{array}{l}\text { Convencional } \\
\text { + Orgânico }\end{array}$} & \multirow{4}{*}{\multicolumn{3}{|c|}{$\begin{array}{c}\text { Época de Colheita } \\
\text { Precipitação Pluviométrica } \\
\text { TCH }\end{array}$}} & \multicolumn{3}{|c|}{ Época de Colheita } & \multicolumn{3}{|c|}{ Precipitação Pluviométrica } & \multicolumn{3}{|c|}{$\mathrm{TCH}$} \\
\hline & & & & \multicolumn{3}{|c|}{1} & \multicolumn{3}{|c|}{$\ln ^{2}-{ }^{3}-$} & \multicolumn{3}{|c|}{-} \\
\hline & & & & \multicolumn{3}{|c|}{$0,299 * *$} & \multicolumn{3}{|c|}{1} & \multicolumn{3}{|c|}{-} \\
\hline & & & & & $-0,052 \mathrm{~ns}$ & & \multicolumn{3}{|c|}{$0,133 \mathrm{~ns}$} & \multicolumn{3}{|c|}{1} \\
\hline \multirow[t]{4}{*}{ Convencional } & \multirow{4}{*}{\multicolumn{3}{|c|}{$\begin{array}{c}\text { Época de Colheita } \\
\text { Precipitação Pluviométrica } \\
\text { TCH }\end{array}$}} & \multicolumn{3}{|c|}{ Época de Colheita } & \multicolumn{3}{|c|}{ Precipitação Pluviométrica } & \multicolumn{3}{|c|}{$\mathrm{TCH}$} \\
\hline & & & & \multicolumn{3}{|c|}{1} & \multicolumn{3}{|c|}{-} & \multicolumn{3}{|c|}{-} \\
\hline & & & & \multicolumn{3}{|c|}{$0,284 * *$} & \multicolumn{3}{|c|}{1} & \multicolumn{3}{|c|}{-} \\
\hline & & & & \multicolumn{3}{|c|}{$0,054 \mathrm{~ns}$} & \multicolumn{3}{|c|}{$0,169 *$} & \multicolumn{3}{|c|}{1} \\
\hline \multirow[t]{7}{*}{ Orgânico } & & & & & oca de Colheita & & Precip & tação Pluviométr & & & $\mathrm{TCH}$ & \\
\hline & & ca de Colheita & & & 1 & & & - & & & - & \\
\hline & Precip & ção Pluviométr & & & $0,100 \mathrm{~ns}$ & & & 1 & & & - & \\
\hline & & $\mathrm{TCH}$ & & & $0,357^{*}$ & & & $-0,231 \mathrm{~ns}$ & & & 1 & \\
\hline & & & & & Sistemas & onvenc & pnal e Orgá & nico & & & & \\
\hline & & rte da Cultura & & & orte da Cultur & & $3^{\circ}$ & orte da Cultura & & & orte da Cultur & \\
\hline & $\begin{array}{l}\text { Época de } \\
\text { Colheita }\end{array}$ & $\begin{array}{l}\text { Precipitação } \\
\text { Pluviométrica }\end{array}$ & $\mathrm{TCH}$ & $\begin{array}{l}\text { Época de } \\
\text { Colheita }\end{array}$ & $\begin{array}{l}\text { Precipitação } \\
\text { Pluviométrica }\end{array}$ & $\mathrm{TCH}$ & $\begin{array}{l}\text { Época de } \\
\text { Colheita }\end{array}$ & $\begin{array}{l}\text { Precipitação } \\
\text { Pluviométrica }\end{array}$ & $\mathrm{TCH}$ & $\begin{array}{l}\text { Época de } \\
\text { Colheita }\end{array}$ & $\begin{array}{l}\text { Precipitaçãa } \\
\text { Pluviométrica }\end{array}$ & $\mathrm{TCH}$ \\
\hline Ép. Colheita & 1 & - & - & 1 & - & - & 1 & - & - & 1 & - & - \\
\hline Precipitação & $0,497 * *$ & 1 & - & $0,312 *$ & 1 & - & $-0,073 \mathrm{~ns}$ & 1 & - & $0,495 * *$ & 1 & - \\
\hline $\mathrm{TCH}^{3}$ & $-0,011 \mathrm{~ns}$ & $-0,146 n s$ & 1 & $-0,057 \mathrm{~ns}$ & $-0,139 \mathrm{~ns}$ & 1 & $-0,162 \mathrm{~ns}$ & $0,141 \mathrm{~ns}$ & 1 & $-0,213 \mathrm{~ns}$ & $-0,068 \mathrm{~ns}$ & 1 \\
\hline & & & & & & ma Co & vencional & & & & & \\
\hline & & rte da Cultura & & & orte da Cultur & & $3^{\circ}$ & orte da Cultura & & & orte da Cultur & \\
\hline & $\begin{array}{l}\text { Época de } \\
\text { Colheita }\end{array}$ & $\begin{array}{l}\text { Precipitação } \\
\text { Pluviométrica }\end{array}$ & $\mathrm{TCH}$ & $\begin{array}{l}\text { Época de } \\
\text { Colheita }\end{array}$ & $\begin{array}{l}\text { Precipitação } \\
\text { Pluviométrica }\end{array}$ & $\mathrm{TCH}$ & $\begin{array}{l}\text { Época de } \\
\text { Colheita }\end{array}$ & $\begin{array}{l}\text { Precipitação } \\
\text { Pluviométrica }\end{array}$ & $\mathrm{TCH}$ & $\begin{array}{l}\text { Época de } \\
\text { Colheita }\end{array}$ & $\begin{array}{l}\text { Precipitação } \\
\text { Pluviométrica }\end{array}$ & $\mathrm{TCH}$ \\
\hline Ép. Colheita & 1 & - & - & 1 & - & - & 1 & - & - & 1 & - & - \\
\hline Precipitação & $0,462 * *$ & 1 & - & $0,332 *$ & 1 & - & $-0,065 \mathrm{~ns}$ & 1 & - & $0,495 * *$ & 1 & - \\
\hline $\mathrm{TCH}$ & $0,00 \mathrm{~ns}$ & $-0,144 n s$ & 1 & $-0,041 \mathrm{~ns}$ & $-0,141 n s$ & 1 & $-0,112 \mathrm{~ns}$ & $0,119 \mathrm{~ns}$ & 1 & $-0,253 \mathrm{~ns}$ & $-0,071 \mathrm{~ns}$ & 1 \\
\hline & & & & & & tema C & gânico & & & & & \\
\hline & & rte da Cultura & & & orte da Cultur & & $3^{\circ}$ & orte da Cultura & & $4^{\circ}$ & orte da Cultur & \\
\hline & $\begin{array}{l}\text { Época de } \\
\text { Colheita }\end{array}$ & $\begin{array}{l}\text { Precipitação } \\
\text { Pluviométrica }\end{array}$ & $\mathrm{TCH}$ & $\begin{array}{l}\text { Época de } \\
\text { Colheita }\end{array}$ & $\begin{array}{l}\text { Precipitação } \\
\text { Pluviométrica }\end{array}$ & $\mathrm{TCH}$ & $\begin{array}{l}\text { Época de } \\
\text { Colheita }\end{array}$ & $\begin{array}{l}\text { Precipitação } \\
\text { Pluviométrica }\end{array}$ & $\mathrm{TCH}$ & $\begin{array}{l}\text { Época de } \\
\text { Colheita }\end{array}$ & $\begin{array}{l}\text { Precipitação } \\
\text { Pluviométrica }\end{array}$ & $\mathrm{TCH}$ \\
\hline Ép. Colheita & 1 & - & - & 1 & - & - & 1 & - & - & 1 & - & - \\
\hline Precipitação & $0,843 * *$ & 1 & - & $0,387 \mathrm{~ns}$ & 1 & - & $0,051 \mathrm{~ns}$ & 1 & - & $0,961 * *$ & 1 & - \\
\hline $\mathrm{TCH}$ & $-0,111 \mathrm{~ns}$ & $-0,164 n s$ & 1 & $-0,339 n s$ & $-0,182 \mathrm{~ns}$ & 1 & $-0,097 \mathrm{~ns}$ & $0,456 \mathrm{~ns}$ & 1 & $-0,208 \mathrm{~ns}$ & $-0,157 \mathrm{~ns}$ & 1 \\
\hline
\end{tabular}


Provavelmente o fator que pode ter contribuído para o baixo valor de correlação foi a variação no volume de precipitação pluviométrica acumulado durante o ciclo da cultura entre os períodos de colheita (outono, inverno e primavera), nos quatro ciclos da cana-de-açúcar. Gava et al. (2011) estudaram o efeito da precipitação pluviométrica na produtividade da cana-deaçúcar em dois ciclos da cultura cultivada no Argissolo eutrófico no munícipio de Jaú. SP, e concluíram que a redução no volume de precipitação pluviométrica de $1480 \mathrm{~mm}$ para 1397 $\mathrm{mm}$ entre primeiro e segundo ciclos da cultura respectivamente, proporcionaram os menores valores de produtividade da cana-de-açúcar em função da menor produção de colmos pelo menor índice pluviométrico.

No entanto, no sistema orgânico ocorreu o inverso, a correlação entre o TCH e a precipitação pluviométrica foi de $-23,10 \%$, ou seja, a falta de precipitação pluviométrica durante o período de colheita, uma vez que a cana-de-açúcar só é colhida no inverno, provavelmente foi a responsável pela redução da produtividade da cultura. Ressalta-se que nos municípios de Goiatuba e Bom Jesus, posição geográfica das lavouras da Usina Goiasa, o inverno é caracterizado pelo baixo índice pluviométrico, com valores de precipitação pluviométrica acumulada na estação (Climatempo, 2016). Entretanto, no sistema associado (convencional e orgânico) o valor da correlação entre o TCH e a precipitação pluviométrica foi de $-13,30 \%$, provavelmente pela maior influência da correlação negativa no sistema de cultivo orgânico. Abreu et al. (2013) avaliaram a produtividade da cana-de-açúcar em Latossolo Amarelo coeso argissólico no município de Rio Largo, AL, e concluíram que o menor volume de precipitação pluviométrica acumulado no ano de 2007 limitou a produtividade da cultura no segundo corte e que o maior índice pluviométrico no ano seguinte aumentou a produtividade da cana-de-açúcar no terceiro corte da cultura. Demattê e Demattê (2009) concluíram o aumento do TCH na cultura da cana-de-açúcar está relacionado à distribuição da precipitação pluviométrica durante o ciclo da cultura, sendo mais importante nos períodos de maior estresse hídrico para a cultura (inverno e primavera).

No sistema convencional a correlação entre o $\mathrm{TCH}$ e os períodos de colheita não foram significativas, obtendo o valor de 5,40\% (Tabela 3). Provavelmente, o valor médio dos quatro ciclos de cultivo esteja compromentendo o comportamento da produtividade da cultura em cada ciclo e os períodos de colheita da cana-de-açúcar. Os estudos de Demattê e Demattê (2009), demonstraram a redução na produtividade da cana-de-açúcar em função do período de colheita, sendo mais limitante para a cana-de-açúcar colhida na primavera em Neossolo Quartzarênico, devido à baixa soma de bases e retenção hídrica desta classe de solo. Os 
mesmo autores observaram a redução de $20 \mathrm{Mg} \mathrm{ha}^{-1}$ na cana-de-açúcar, variedade RB72454, cultivada em Argissolo Vermelho colhida no período de outono (98 $\mathrm{Mg} \mathrm{ha}^{-1}$ ) comparada ao período de colheita de primavera ( $\left.78 \mathrm{Mg} \mathrm{ha}^{-1}\right)$ no município de Quatá, estado de São Paulo. Já no sistema orgânico a maior correlação foi verificada entre a produtividade da cana-de-açúcar e a época de colheita, com o valor de $35,70 \%$. Na Usina Goiasa, o corte da cultura sob manejo orgânico é realizado somente no inverno, para o beneficiamento do açúcar orgânico sendo este o motivo do valor da correlação. Segundo Landell e Bressiane (2010) a condição para o maior acúmulo de açúcar na cultura ocorre no período de colheita - inverno, devido à maturação da cana em condições de baixa precipitação pluviométrica e maior intensidade de luz. Por outro lado, Silva et al. (2008), observaram aumento crescente na quantidade de açúcar e produtividade da cultura da cana-de-açúcar nas épocas de colheita de outono a primavera, devido ao aumento da temperatura e precipitação pluviométrica. Na associação dos sistemas de cultivo (convencional e orgânico) a correlação entre o TCH e o período de colheita foi de $-5,2 \%$. Possivelmente o maior número de dados $(\mathrm{n}=169)$ no sistema convencional comparado ao sistema orgânico $(n=32)$ influenciou no valor da correlação. Para a melhor compreensão sobre a influência da precipitação pluviométrica na produtividade da cana-de-açúcar na região de estudo, a tabela 4 apresenta os valores médios, desvio padrão e número de amostras (n) do volume de precipitação pluviométrica acumulada em cada período de colheita e ciclo da cultura nas diferentes classes de solos e sistemas de cultivo. Silva et al. (2008) avaliaram a produtividade da cana-de-açúcar cultivada em Latossolo Vermelho Eutroférrico do município de Jaú, SP, sob diferentes períodos de colheita e concluíram que o volume de precipitação pluviométrica acumulado de $91 \mathrm{~mm}$ entre os períodos de colheita de inverno e primavera elevou a produtividade da cana-de-açúcar. Mediante os resultados da precipitação pluviométrica acumulada nota-se grande variação nos valores desta variável nas diferentes classes de solos e períodos de colheita, conforme atesta o valor de desvio padrão (Tabela 4). No sistema orgânico, nas classes de solos 4 e 5 (LVdf1.1 e LVdf1.4) foi constatado o menor o valor de desvio padrão, no quarto ciclo da cultura, o que pode ser explicado pelo menor número de dados (n) obtidos neste sistema de cultivo (Tabela 4). Resultados semelhantes foram identificados nas classes de solos dois (LVdf.1.4) e três (LVwf.1.4) em sistema convencional no quarto ciclo de cultivo no período de colheita de outono. 
Tabela 4. Volume de precipitação pluviométrica acumulado $(\mathrm{mm})$ em cada classe de solo em diferentes cortes na região de estudo.

\begin{tabular}{|c|c|c|c|c|c|c|c|c|c|c|}
\hline & \multirow[b]{2}{*}{ Classes de Solos } & \multicolumn{3}{|c|}{ Época de Colheita - Outono } & \multicolumn{3}{|c|}{ Época de Colheita - Inverno } & \multicolumn{3}{|c|}{ Época de Colheita - Primavera } \\
\hline & & Média & Desvio Padrão & $\mathrm{n}$ & Média & Desvio Padrão & $\mathrm{n}$ & Média & Desvio Padrão & $\mathrm{n}$ \\
\hline & 1 & $1.628,50$ & 54,66 & 7 & $1.587,69$ & 152,17 & 9 & $1.696,90$ & 307,11 & 11 \\
\hline & 2 & $2.173,79$ & 0,00 & 1 & $1.956,80$ & 60,90 & 2 & $2.374,40$ & 414,89 & 5 \\
\hline \multirow[t]{5}{*}{$1^{\circ}$ Corte } & 3 & - & - & - & $1.535,59$ & 117,83 & 4 & $1.949,91$ & 513,86 & 6 \\
\hline & 4 & - & - & - & $1.280,49$ & 12,32 & 4 & - & - & - \\
\hline & 5 & - & - & - & $1.437,17$ & 135,36 & 5 & - & - & - \\
\hline & 1 & $1.317,33$ & 145,04 & 8 & $1.372,62$ & 163,85 & 10 & $1.543,07$ & 244,49 & 9 \\
\hline & 2 & $1.427,07$ & 125,56 & 3 & $1.173,49$ & 0,00 & 1 & $1.294,21$ & 339,24 & 4 \\
\hline \multirow[t]{5}{*}{$2^{\circ}$ Corte } & 3 & $1.549,49$ & 25,57 & 2 & $1.173,49$ & 0,00 & 1 & $1.662,20$ & 321,50 & 7 \\
\hline & 4 & - & - & - & $1.474,66$ & 173,89 & 4 & - & - & - \\
\hline & 5 & - & - & - & $1.450,26$ & 152,84 & 5 & - & - & - \\
\hline & 1 & $1.538,44$ & 46,07 & 6 & $1.522,10$ & 94,30 & 10 & $1.545,20$ & 263,63 & 11 \\
\hline & 2 & $1.306,87$ & 85,39 & 2 & - & - & - & $1.278,04$ & 188,05 & 6 \\
\hline \multirow[t]{5}{*}{$3^{\circ}$ Corte } & 3 & - & - & - & $1.560,39$ & 31,79 & 2 & $1.393,02$ & 281,57 & 8 \\
\hline & 4 & - & - & - & $1.402,05$ & 138,99 & 4 & - & - & - \\
\hline & 5 & - & - & - & $1.558,05$ & 17,01 & 5 & - & - & - \\
\hline & 1 & $1.397,78$ & 19,05 & 5 & $1.344,03$ & 184,08 & 6 & $1.613,36$ & 104,32 & 9 \\
\hline & 2 & $1.460,69$ & 0,00 & 1 & $1.497,06$ & 0,00 & 1 & $1.649,00$ & 133,69 & 6 \\
\hline \multirow[t]{3}{*}{$4^{\circ}$ Corte } & 3 & $1.423,64$ & 0,00 & 1 & $1.412,01$ & 115,69 & 2 & $1.537,12$ & 210,53 & 3 \\
\hline & 4 & - & - & - & $1.575,06$ & 0,00 & 3 & - & - & - \\
\hline & 5 & - & - & - & $1.461,69$ & 0,00 & 2 & - & - & - \\
\hline
\end{tabular}


No período de colheita - primavera, os maiores valores de desvio padrão no primeiro, segundo e terceiro cortes da cultura se devem a grande heterogeneidade dos dados obtidos na Usina Goiasa (tabela 4).

No sistema convencional as variáveis precipitação pluviométrica acumulada no ciclo da cultura e as época de colheita (Tabela 3) apresentaram maiores correlações, ou seja: $46,20 \%$ no primeiro corte, $33,20 \%$ no segundo corte, atingindo $49,50 \%$ no quarto corte, sendo que no terceiro corte, esta tendência não foi verificada, com correlação negativa não significativa de $-6,50 \%$. Estes resultados no terceiro ciclo $(-6,50 \%)$ devem estar associados aos menores valores de precipitação pluviométrica nos períodos de outono e primavera, conforme dados expressos na tabela 4. Demattê e Demattê (2009) demonstraram que a necessidade de água para a produção de uma tonelada de cana-de-açúcar aumenta do período de colheita - outono para o inverno, devido ao estresse hídrico ao longo do ciclo da cultura.

Já no sistema orgânico as maiores correlações foram constatadas entre as mesmas variáveis descritas para o sistema convencional (precipitação pluviométrica acumulada no ciclo da cultura e período da colheita), com 84,30, 38,70 e 96,10\%, respectivamente para o primeiro, segundo e quarto cortes da cultura (Tabela 3). No terceiro corte no período de colheita de inverno o comportamento foi semelhante ao ocorrido no cultivo convencional com valor não significativo de 5,10\% (Tabela 3). De acordo com os dados da Usina Goiasa, a cultura da cana-de-açúcar em sistema orgânico é colhida no período de colheita de inverno, fato este que intensifica o valor da correlação de acordo com o volume de precipitação pluviométrica acumulado nas classes de solos quatro e cinco (Tabela 4) no inverno. No entanto, Landell e Bressiane (2010) indicaram que o maior potencial produtivo das variedades de cana-de-açúcar é obtido na colheita de outono, devido a melhor condição climática, contudo, os mesmos autores observaram que os altos teores de sacarose da cultura são obtidos na safra de inverno. Ressalta-se que a produção de cana-de-açúcar sob sistema orgânico na Usina Goiasa prioriza a produção do açúcar. No conjunto dos sistemas de cultivo orgânico e convencional as variáveis precipitação pluviométrica acumulada no ciclo da cultura e as épocas de colheita mostraram correlações de 49,70, 31,20 e 49,50\%, respectivamente para o primeiro, segundo e quarto cortes (Tabela 3). No terceiro corte na colheita de inverno o comportamento foi semelhante ao ocorrido no cultivo convencional e orgânico com valor não significativo de 7,30\% (Tabela 3). Os baixos valores da correlação no terceiro ciclo da cultura estão relacionados ao menor índice pluviométrico nos períodos de outono e primavera no sistema convencional e o elevado número de dados (n) deste sistema comparado ao sistema orgânico que influenciaram no resultado da correlação (Tabela 4). Entretanto, o resultado da 
correlação no conjunto (sistema orgânico e convencional) entre a precipitação pluviométrica e as épocas de colheita foi de $29,90 \%$ na média dos quatro ciclos de cultivo (Tabela 3), o menor da correlação deve-se ao baixo valor obtido no terceiro ciclo da cultura em ambos os sistemas de cultivo.

No sistema convencional a avaliação por ciclo da cultura entre as variáveis TCH e precipitação pluvimétrica apresentam correlações de -14,40 \% no primeiro corte, $-14,10 \%$ no segundo corte, 11,90 no terceiro corte e $-7,10 \%$ no quarto corte. Por outro lado, a produtividade de colmos por hectare $(\mathrm{TCH})$ da cana-de-açúcar correlacionou-se com a precipitação pluviométrica acumulada nos solos em 16,90\% no sistema convencional ao considerar a média dos quatros cortes. Os resultados mostram que o efeito de cada variável comporta-se de maneira distinta quando se avalia por ciclo da cultura e pela média dos quatro cortes. Aude et al. (1992) estudaram o comportamento na produtividade da cana-de-açúcar em diferentes épocas de plantio no Argissolo Vermelho-Amarelo Distrófico, sendo que os cortes realizados no inverno apresentaram baixas produtividades, em função das condições climáticas adversas (estresse hídrico e baixas temperaturas) na região de Santa Maria, RS. No sistema orgânico as variáveis $\mathrm{TCH}$ e a precipitação pluviométrica também mostraram correlações negativas entre si, nos cortes 1, 2 e 4 (sendo de -16,40\% -18,20 e -15,70\%, respectivamente). No terceiro corte da cultura, a correlação entre estas variáveis (TCH e precipitação pluviométrica) foi de $45,6 \%$ (Tabela 3), provavelmente em função dos dados mais uniformes de precipitação pluviométrica na classes de solos cinco de acordo com os baixos valores de desvio padrão no terceiro corte (Tabela 2). No entanto, no sistema orgânico ocorreu o inverso, a correlação entre o TCH e a precipitação pluviométrica na média dos quatro ciclos foi de - 23,10\%, ou seja, a falta de precipitação pluviométrica nos cortes avaliados, uma vez que a cana-de-açúcar só é colhida no inverno (época de colheita 2). Aquino et al. (2015) demonstraram que a palhada sobre a superfície do solo proporcionou maior infiltração e retenção de água no Latossolo Vermelho Eutroférrico do município de Bandeirantes, PR, cultivados com cana-de-açúcar não afetando a produtividade da cultura em condição de estiagem prolongada. No conjunto dos sistemas de cultivo orgânico e convencional as variáveis precipitação TCH e pluviométrica acumulada no ciclo da cultura mostraram correlações de $-14,60 ;-13,90 ; 14,10$ e $-6,80 \%$, respectivamente para o primeiro, segundo, terceiro e quarto cortes. A variável precipitação pluviométrica afetou de maneira diferente cada corte da cultura no conjunto de sistemas orgânico e convencional. Entretanto, o resultado da correlação no conjunto (sistema orgânico e convencional) entre o TCH e a 
precipitação pluviométrica foi de $13,30 \%$ na média dos quatro ciclos de cultivo, demonstrando o comportamento distinto das variáveis em cada sistema de cultivo (Tabela 3 ).

Já a correlação entre o TCH e as épocas de colheita no sistema convencional apresentaram correlações nulas e negativas nos quatro ciclos da cultura, com os seguintes valores: zero $(0,00 \%)$ para o primeiro corte, $-4,10 \%$ para o segundo corte, $-11,20 \%$ para o terceiro corte e $-25,3 \%$ no quarto corte. A queda da produtividade a partir do segundo ciclo da cultura (Tabela 3) pode ser explicado pela fertilidade do solo em subsuperfície ou menor perfilhamento das soqueiras (ciclos 2, 3 e 4) ao longo do tempo. Resultado semelhante foi apresentado por Ambrosano et al. (2011) que relatam que a queda de produtividade da cana planta (primeiro corte) para os cortes posteriores (soqueiras) ocorre em função de mudanças climáticas em cada corte da cultura da cana-de-açúcar.

Entretanto, Gava et al. (2011) demonstram o efeito positivo da produtividade da canade-açúcar e o volume de precipitação pluviométrica acumulado durante o ciclo da cultura, sendo o fator responsável pela maior produtividade da cana-de-açúcar no segundo corte em relação ao primeiro corte da cultura que obteve o menor acúmulo de precipitação pluviométrica. Os maiores valores de correlação negativa no terceiro e quarto ciclos da cultura da cana-de-açúcar podem estar relacionados com a dependência das propriedades químicas das classes de solos em subsuperfície. Landell et al. (2003) demonstraram que a partir do terceiro corte o caráter químicos dos Latossolos em profundidade proporcionou a maior produtividade e longevidade da cultura da cana-de-açúcar. Landell et al. (2005) destacam que em solos férteis e elevada disponibilidade hídrica, são mais indicados para a colheita de primavera (época de colheita - 3), entretanto, algumas variedades rústicas são mais produtivas quando colhidas na primavera em função do seu potencial genético.

No entanto, no sistema convencional a correlação entre o TCH e a época de colheita na média dos quatro ciclos foi de $-5,40 \%$, ou seja, o efeito das correlações do primeiro ciclo $(0,00 \%)$ e segundo ciclo $(-4,10 \%)$ podem estar contribuindo para o valor da correlação quando se considera a médias dos quatro cortes.

Já no sistema orgânico as variáveis $\mathrm{TCH}$ e a época de colheita da cultura apresentaram, os seguintes valores de correlação: $-11,1 \%$ no primeiro corte; $-33,9 \%$ para o segundo corte, $-9,7 \%$ no terceiro corte e $-20,8 \%$ para o quarto corte. Estes resultados indicam que a redução na produtividade da cultura da cana-de-açúcar ocorre com o passar dos dias dentro do período de colheita de inverno, período destinado pela Usina Goiasa para a colheita da cultura em sistema orgânico, porém com diferentes valores de correlação entre os ciclos da cana-de-açúcar. 
Aude et al. (1992) atribuíram a redução da produtividade da cultura da cana-de-açúcar no período de colheita de inverno à condição climática de baixas temperaturas e baixos índices pluviométricos no município de Santa Maria, RS. No entanto, ao considerar a correlação entre o TCH e a época de colheita na média dos quatro cortes a correlação atingiu o valor de 35,70\% (Tabela 3) ou seja, na média dos quatro cortes da cultura o TCH têm correlação com a época de colheita realizada somente no período de colheita de inverno (Tabela 2). No conjunto dos sistemas de cultivo orgânico e convencional as variáveis TCH e as épocas de colheita em cada corte mostraram correlações de -1,10; -5,70; -16,20 e -21,30\%, respectivamente para o primeiro, segundo, terceiro e quarto cortes.

Os resultados indicam a redução da produtividade da cultura da cana-de-açúcar ao longo das épocas de colheita, semelhante ao observado no sistema convencional, e explicado pelo grande número de dados (n) comparado ao sistema de cultivo orgânico, que influenciaram nas correlações (Tabela 3). Ao analisar o cultivo associado (convencional e orgânico) o valor de correlação - 5,20 \% para a média dos quatro ciclos de cultivo, não demonstraram o efeito dos maiores valores de correlação no sistema orgânico $(35,70 \%)$, provavelmente pelo diferente número de dados em cada sistema de cultivo sendo $(n=32)$ para o sistema orgânico e $(n=169)$ para o sistema convencional.

\section{II.3.3. Relação entre variáveis e a produtividade da cana-de-açúcar}

Para explicar a variável produtividade (dependente) em função das variáveis sistemas de cultivo em diferentes classes de solos, precipitação pluviométrica acumulada, épocas de colheita e número de cortes (independentes) foi adotado o modelo de regressão linear múltipla.

As estimativas dos coeficientes das variáveis independentes e do intercepto para o modelo de regressão linear múltipla encontram-se na tabela 5.

$\mathrm{Na}$ equação de regressão linear múltipla o intercepto (X0) refere-se a produtividade da cana-de-açúcar em sistema orgânico no primeiro corte na classe de solo quatro (LVdf.1.1) (Tabela 1). A variável (X1) indica a produtividade da cana-de-açúcar no sistema convencional no primeiro corte na classe de solo um (LVdf.1.1), a variável (X2) a produtividade da canade-açúcar no sistema convencional no primeiro corte na classe de solo dois (LVdf.1.4); variável (X3) a produtividade da cana-de-açúcar no sistema convencional no primeiro corte na classe de solo três (LVwf.1.4); variável (X4) a produtividade da cana-de-açúcar no sistema orgânico no primeiro corte na classe de solo cinco (LVdf.1.4), variável (X5) a precipitação pluviométrica acumulada durante o ciclo da cultura (mm); variável (X6) a produtividade da 
cultura no segundo corte; variável (X7) a produtividade da cultura no terceiro corte; variável (X8) a produtividade da cultura no quarto corte e a variável (X9) época da colheita da cultura (dia Juliano).

Tabela 5. Coeficientes não padronizados relativos ao teste $t$, para os coeficientes da regressão linear múltipla da produtividade da cana-de-açúcar na região de estudo.

\begin{tabular}{|c|c|c|c|c|}
\hline & Coeficientes $\mathrm{N}$ & o Padronizados & & \\
\hline Variáveis & $\beta$ & Erro Padrão & Teste $\mathrm{t}$ & Significância \\
\hline $\mathrm{X} 0=$ Intercepto & 119,673 & 10,611 & 11,278 & 0,00 \\
\hline $\begin{array}{l}\mathrm{X} 1 \text { = Sistema convencional/Classe de } \\
\text { solo } 1\end{array}$ & $-3,607$ & 5,741 & $-0,628$ & 0,53 \\
\hline $\begin{array}{l}\mathrm{X} 2 \text { = Sistema convencional/Classe de } \\
\text { solo } 2\end{array}$ & $-5,429$ & 4,101 & $-1,324$ & 0,19 \\
\hline $\begin{array}{l}\text { X3 = Sistema convencional/Classe de } \\
\text { solo } 3\end{array}$ & $-3,176$ & 3,968 & $-0,801$ & 0,42 \\
\hline X4 = Sistema orgânico/Classe de solo 5 & $-3,807$ & 7,197 & $-0,529$ & 0,60 \\
\hline X5 = Precipitação Pluviométrica & $-0,003$ & 0,006 & $-0,566$ & 0,57 \\
\hline $\begin{array}{l}\text { X6 }=\text { Produtividade no segundo ciclo da } \\
\text { cultura }\end{array}$ & $-23,296$ & 4,125 & $-5,647$ & 0,00 \\
\hline $\begin{array}{l}\text { X7 = Produtividade no terceiro ciclo da } \\
\text { cultura }\end{array}$ & $-33,813$ & 4,088 & $-8,271$ & 0,00 \\
\hline $\begin{array}{l}\mathrm{X} 8=\text { Produtividade no quarto ciclo da } \\
\text { cultura }\end{array}$ & $-43,619$ & 4,371 & $-9,980$ & 0,00 \\
\hline X9 = Período de colheita & $-0,013$ & 0,023 & $-0,583$ & 0,56 \\
\hline
\end{tabular}

Apesar de não ser significativo (Tabela 5), o valor do coeficiente não padronizado ( $\beta$ ) indicou que a produtividade da cana-de-açúcar no sistema convencional na classe de solo dois (LVdf1.4) foi inferior em relação à classe de solo três (LVwf1.4) em 2,25Mg ha-1, contradizendo os dados obtidos por Landell et al. (2003); Demattê e Demattê (2009) e Joaquim et al. (1997) que destacam a menor produtividade da cana-de-açúcar em Latossolos ácricos em relação aos Latossolos distróficos em função do baixo teor de bases trocáveis em subsuperfície. Já a cana-de-açúcar cultivada em sistema orgânico foi mais produtiva na classe de solo quatro (LVdf1.1), comparado as demais classes de solos (Tabela 5). Provavelmente, a condição química de subsuperfície associada ao histório das áreas que recebem vinhaça e torta de filtro há muitos anos favoreceu a melhora dos atributos químicos do solo e a produtividade da cultura. Segundo Canellas et al. (2003) a utilização de vinhaça em Cambissolos cultivados com cana-de-açúcar no município de Campos dos Goytacazes (RJ), contribuiu para o aumento 
da matéria orgânica e da melhoria da fertilidade do solo devido à sua composição química enriquecida com ácidos fúlvicos e nutrientes. Na mesma linha de pesquisa, Paulino et al. (2011), concluíram que o nutriente potássio (K) presente na vinhaça aumentou a produtividade da cana-de-açúcar em Latossolo Vermelho da Cidade Gaúcha, PR. Caione et al. (2015) avaliaram o efeito da associação adubo orgânico (torta de filtro) + fontes de fósforo inorgânico na presença e ausência de composto orgânico em Argissolo Vermelho Eutrófico, cujo efeito da associação do adubo orgânico + inorgânico elevou a produtividade na canaplanta, porém sem a necessidade de quantidades maiores de fertilizante mineral. $\mathrm{Na}$ comparação entre as classes de solos cultivadas em sistema orgânicos (classes 4 e 5) o efeito da fertilidade em profundidade pode ter contribuído para a diferença na produtividade da cultura entre as classes de solos. Na mesma linha de pesquisa Demattê e Demattê (2009) e Landell et al. (2003) observaram a relação dos diferentes valores de soma de bases na subsuperfície dos Latossolos distróficos e a produtividade das soqueiras da cana-de-açúcar em diferentes regiões brasileiras.

A variável precipitação pluviométrica acumulada $(\mathrm{mm})$ no ciclo da cultura pouco influenciou a produtividade da cultura da cana-de-açúcar em sistema orgânico e convencional $(\beta=-0,003)$ na região estudada (Tabela 5). Provavelmente a quantidade de precipitação pluviométrica acumulada durante as três épocas de colheita no sistema convencional e o histórico de fertilidade do solo das áreas de cana-de-açúcar em sistema orgânico colhida no inverno tenha atenuado o efeito da variável na produtividade da cana-de-açúcar.

Entretanto, Ambrosano et al. (2011) relatam que a redução em $357 \mathrm{~mm}$ entre o primeiro e segundo ciclos da cana-de-açúcar cultivada em Argissolo Vermelho-Amarelo Distrófico, foi o principal fator na redução da produtividade da cultura no município de Piracicaba, SP. Silva et al. (2008) concluíram que o volume de precipitação pluviométrica de $91 \mathrm{~mm}$ no mês de setembro foi o responsável por elevar a produtividade da cultura da canade-açúcar cultivada em Latossolo Vermelho Eutroférrico no município de Jaú, SP. Por outro lado, Dantas Neto et al. (2006) não observaram efeitos significativos na produtividade da cana-de-açúcar com adoção de irrigação, devido ao volume de precipitação pluviométrica acumulada durante a condução do experimento em Argissolo Vermelho-Amarelo abrúptico no município de Capim, PB.

Os cortes (primeiro ao quarto) foram as variáveis significativas que influenciaram a produtividade da cultura da cana-de-açúcar na região estudada (Tabela 5). No primeiro corte, considerado de maneira geral o mais produtivo para a cultura independente da classe de solos e sistema de cultivo (Tabela 2) a produtividade da cultura foi inferior nos cortes posteriores 
com os seguintes valores: - 23,27 $\mathrm{Mg} \mathrm{ha}^{-1}$ no segundo corte; - 33,81 $\mathrm{Mg} \mathrm{ha}^{-1}$ no terceiro corte e - 43,62 $\mathrm{Mg} \mathrm{ha}^{-1}$ no quarto corte da cultura, comparados ao valor de produtividade do primero corte (cana planta) em ambos os sistemas de cultivo (Tabela 5). Ambrosano et al. (2011) relatam que a queda de produtividade da cana planta para os cortes posteriores ocorre normalmente em função do maior desgaste das soqueiras ao longo dos cortes. Os mesmos autores estudaram o efeito da adubação verde na melhoria da produtividade da cana planta e nas quatro soqueiras da cana-de-açúcar cultivada em Argissolo Vermelho-Amarelo Distrófico, concluindo que a utilização de crotalária júncea elevou a produtividade dos cinco cortes da cana-de-açúcar devido à maior produção de material vegetal e acúmulo de nitrogênio $(\mathrm{N})$ mediante a fixação biológica. A manutenção da palhada na cana-de-açúcar, segundo Aquino et al. (2015), melhorou os atributos físico-hídricos do Latossolo Vermelho Eutroférrico e não reduziu a produtividade das soqueiras da cana-de-açúcar sob estresse hídrico no município de Bandeirantes, PR. De acordo com Silva et al. (2010), um canavial deve ser conduzido por no mínimo cinco a seis cortes para ser considerado economicamente produtivo ou até quando a produtividade média atingir ao redor de $65 \mathrm{Mg} \mathrm{ha}^{-1}$, entretanto, outras variáveis como: uso de irrigação, sistema de cultivo, dentre outras práticas devem ser consideradas para determinar a necessidade da renovação ou permanência da soqueiras no campo.

A época de colheita, pouco afetou a produtividade da cana-de-açúcar segundo o coeficiente gerado pelo procedimento Enter com o valor de $(\beta=-0,013)$ (Tabela 5). Ressalta-se que na Usina Goiasa, a colheita da cana-de-açúcar em sistema convencional é realizada nas épocas de corte de outono (período de colheita 1), inverno (período de colheita 2) e primavera (período de colheita 3) e a colheita no sistema orgânico no inverno (período de colheita 2). O manejo diferenciado entre os dois sistemas de cultivo pode ter reduzido o efeito desta variável na produtividade da cana-de-açúcar. Entretanto, Landell e Bressiane (2010); Demattê e Demattê (2009) relatam que a colheita da cana-de-açúcar realizada no período de outono (período de colheita 1) torna a cultura da cana-de-açúcar mais produtiva em decorrência das melhores condições climáticas ao longo do ciclo. Por outro lado, Landell et al. (2005) concluíram que variedades mais rústicas quando colhidas no período da primavera em solos de elevada fertilidade e disponibilidade hídrica são mais produtivas que variedades de cana-de-açúcar mais exigentes em condições de solo e clima (responsivas e intermediárias) devido a melhor adaptação de algumas variedades rústicas na terceira época de colheita (primavera). Entretanto, cabe salientar que as usinas geralmente têm grandes extensões de 
terra, ou seja, o planejamento de colheita não é realizado somente em uma época de colheita específica devendo comtemplar as três épocas de colheita.

Como não houve diferença significativa na produtividade da cana-de-açúcar cultivada em sistema convencional e orgânico nas cinco classes de solos, não foi necessário estabelecer novos modelos para cada sistema de cultivo. Portanto, a variável corte da cultura foi a responsável pelas diferenças de produtividade da cultura da cana-de-açúcar em sistema orgânico e convencional cultivadas em Latossolos férricos muito argilosos do município de Goiatuba, GO.

\section{II.4. CONCLUSÕES}

1. As maiores produtividades da cana-de-açúcar, no período de janeiro de 2008 a agosto de 2015 na Usina Goiasa, Goiatuba, GO, foram verificadas nos Latossolos distróficos muito argilosos, com maiores teores de soma de bases em profundidade (LVdf1.1), particularmente quando cultivada em sistema orgânico, até o terceiro corte na colheita de inverno.

2. Por meio de regressão linear múltipla, foi gerado um modelo preditivo da produtividade da cana-de-açúcar na região estudada, com $\mathrm{R}^{2}$ de $40,00 \%$, onde as variáveis que apresentaram maior influência foram os cortes, do primeiro ao quarto, independente do sistema de cultivo e classes de solo, demonstrando que a cultura diminui o potencial produtivo dos cortes da cana-planta em relação aos demais cortes (soqueiras). 


\section{II.5. REFERÊNCIAS BIBLIOGRÁFICAS}

ABREU, M.L.; SILVA, M.A.; TEODORO, I.; HOLANDA, L.A.; SAMPAIO NETO, G.D. Crescimento e produtividade de cana-de-açúcar em função da disponibilidade hídrica dos Tabuleiros Costeiros de Alagoas. Bragantia, Campinas, v. 72, p.262-270, 2013.

ALLEONI, L.R.F.; CAMARGO, O.A. Atributos físicos de Latossolos ácricos do norte paulista. Scientia agricola, v. 51, p. 321-326, 1994.

AMBROSANO, E.J.; CANTARELLA, H.; AMBROSANO, G.M.B.; SCHAMMAS, E.A.; DIAS, F.L.F.; ROSSI, F.; TRIVELIN, P.C.O.; MURAOKA, T. SACHS, R.C.C.; AZCÓN, R. Produtividade da cana-de-açúcar após o cultivo de leguminosas. Bragantia, v. 70, p. 810-818, 2011.

AQUINO, G.S.; MEDINA, C.C.; PORTEIRA JUNIOR, A.L.; SANTOS, L.O.; CUNHA, A.C.B.; KUSSABA, D.A.O.; SANTOS JÚNIOR, J.H.; ALMEIDA, L.F.; SANTIAGO, A.D. Sistema radicular e produtividade de soqueiras de cana-de-açúcar sob diferentes quantidades de palhada. Pesquisa Agropecuária Brasileira, v. 50, p.1150-1159, 2015.

ARIEDI JUNIOR, V.R. Avaliação da sustentabilidade de um sistema de produção de cana-de-açúcar orgânica. São Carlos: Universidade Federal de São Carlos 2013. 241p. Dissertação Mestrado.

AUDE, M.I.S.; PIGNATARO, J.A.B.; MARCHAZAN, E.; PASQUALETTO, A. Época de plantio e seus efeitos na produtividade e teor de sólidos solúveis no caldo da cana-de-açúcar. Ciência Rural, V. 22, p. 131-137, 1992.

CAIONE, G.; PRADO, R.M.; CAMPOS, C.N.S.; MODA, L.R.; VASCONCELOS, R.L.; PIZAURO JÚNIOR, J.M. Response of Sugarcane in a Red Ultisol to Phosphorus Rates, Phosphorus Sources, and Filter Cake. The Scientific World Journal Volume 2015.

CANELLAS, L.P.; VELLOSO, A.C.X.; MARCIANO, C.R.; RAMALHO, J.F.G.P.; RUMJANEK, V.M.; REZENDE, C.E.; SANTOS, G.A. Propriedades químicas de um Cambissolo cultivado com cana-de-açúcar com preservação do palhiço e adição de vinhaça por longo tempo. Revista Brasileira de Ciência do Solo, v. 27. p. 935-944, 2003.

CENTRO DE TECNOLOGIA CANAVIEIRO - CTC. Carta de Solos da Usina Goiasa Goiatuba LTDA. Relatório técnico. 2009.

CLIMATEMPO. Média mensal climática dos últimos 30 anos. Disponível em: http://www.climatempo.com.br/climatologia/1012/goiatuba-go. Acesso em 29/05/2016.

CONAB - Companhia Nacional de Abastecimento. Acompanhamento da safra brasileira: cana-de-açúcar, v. 3 -Safra 2016/2017, n.1 -. Primeiro levantamento, abril/ 2016. Brasília: Conab, 2016. 66p.

COOPER, M.; VIDAL-TORRADO, P. Caracterização morfológica, micromorfológica e físico-hídrica de solos com horizonte B nítico. Revista Brasileira de Ciência do Solo, v. 29. p. 581-595, 2005. 
CUNHA, T.J.F.; BLANCANEAUX, P.; CALDERANO FILHO, B.; CARMO, C.A.F.S.; GARCIA, N.C.P.; LIMA.E.M.B. Influência da diferenciação pedológica no desenvolvimento da seringueira no município de Oratórios, MG. Pesquisa Agropecuária Brasileira, v. 35, p. 145-155, 2000.

DALCHIAVON, F.C.; MOREL, P.C.; MONTANARI, R.; ANDREOTTI, M. Sugarcane productivity correlated with physical-chemical atributes to create soil management zone. Revista Ceres, v. 60, p. 706-714, 2013.

DEMATTÊ, J.L.I.; DEMATTÊ, J.A.M. Ambientes de Produção como estratégia de manejo na cana-de-açúcar. Informações Agronômicas, nº 127, Piracicaba, 2009.

DIAS, F.L.F.; MAZZA, J.A.; MATSUOKA, S.; PERECIN, D.; MAULE, R.F. Produtividade da cana-de-açúcar em relação a clima e solos da região noroeste do estado de São Paulo. Revista Brasileira de Ciência do Solo, v. 23, p. 627-634, 1999.

FERREIRA, I. C. de M.; COELHO, R.M.; TORRES, R.B.; BERNACCI, L.C. Solos e vegetação nativa renascente no município de Campinas. Pesquisa Agropecuária Brasileira, v. 42, p. 1319-1327, 2007.

GAVA, G.J.C.; SILVA, M.A.; SILVA, R.C.; JERONIMO, E.M.; CRUZ, J.C.S.; KÖLLN, O.T. Produtividade de três cultivares de cana-de-açúcar sob manejos de sequeiro e irrigado por gotejamento. Revista Brasileira de Engenharia Agrícola e Ambiental. v. 15, p. 250$255,2011$.

GROSS, R.R.; IZAGUIRRE, Y.P.; LIRANZA, N.B.; SUÁREZ, H.J.; ISAAC, M.T.; CARABALLOSO, V.; LÓPEZ, L.V. Contribución de las localidades de Prueba en estudios multiambientales de caña de azúcar. Cultivos Tropicales, v. 34, p. 38-44, 2013.

HARDY, M. A. Regression with Dummy variables. Series: Quantitative Applications in the Social Science. A Sage University Paper. Editor: Michael S. Lewis-Beck, University of Iowa, 1993.

IBM Corp. Released. IBM SPSS Statistics for Windows, Version 19.0. Armonk, NY: IBM Corp. 2010.

JOAQUIM, A.C; DONZELLI, J.L; QUADROS, A.C; SARTO, L.F. Potencial de produção de cana-de-açúcar. In: Seminário de Tecnologia Agronômica. Centro de Tecnologia Coopersucar. Piracicaba. 1997, p 68-76.

LANDELL, M.G.A.; PRADO, H.; VASCONCELOS, A.C.M.; PERECIN, D.; ROSSETTO, R.; BIDÓIA, M.A.P.; SILVA, M.A.; XAVIER, M.A. Oxisol subsurface chemical atributes related to sugarcane productivity. Scientia Agricola, v. 60, p. 741-745, 2003.

LANDELL, M.G.A.; CAMPANA, M.P.; FIGUEIREDO, P.; VASCONCELOS, A.C.M.; XAVIER, M.A.; BIDÓIA, M.A.P.; PRADO, H.; SILVA, M.A.; DINARDO-MIRANDA, L.L.; SANTOS, A.S.; PERECIN, D.; ROSSETTO, R.; SILVA, D.N.; MARTINS, A.L.M.; GALLO, P.B.; KANTHACK, R.A.D.; CAVICHIOLI, J.C.; VEIGA FILHO, A.A.; ANJOS, I.A.; AZANIA, C.A.M.; PINTO, L.R.; SOUZA, S.A.C.D. Variedades de cana-de-açúcar para o Centro-Sul do Brasil. Boletim técnico, 197, Instituto Agronômico, 2005, 33p. 
LANDELL, M.G.A.; BRESSIANI, J.A. Melhoramento genético e manejo varietal. In: DINARDO-MIRANDA, L.L.; VASCONCELOS, A.C.M.; LANDELL, M.G.A. Cana-deAçúcar, Instituto Agronômico. Campinas. $1^{a}$ Reimpressão. 2010, p. 101-155.

MEDEIROS, J.S.; OLIVEIRA, F.H.T.; ARRUDA, J.A.; VIEIRA, M.S.; FERREIRA, M.P.F. Fontes Eficiência de extratores de potássio disponível em solos do estado da paraíba com graus de desenvolvimento pedogenético diferentes. Revista Brasileira de Ciência do Solo, v. 34, p. 183-194, 2010.

PAULINO, J.; ZOLIN, C. A.; BERTONHA, A.; FREITAS, P. S. L.; FOLEGATTI, M. V. Estudo exploratório do uso da vinhaça ao longo do tempo. II Características da cana-deaçúcar. Revista Brasileira de Ciência do Solo, v. 15, p. 244-249, 2011.

SANTOS, D.H.; TIRITAN, C.S.; FOLONI, J.S.S.; FABRIS, L.B. Produtividade de cana-deaçúcar sob adubação com torta de filtro enriquecida com fosfato solúvel. Pesquisa Agropecuária Tropical. v. 40, p. 454-461, 2010.

SANTOS, H.C.; FRAGA, V.S.; RAPOSO, R.W.C.; PEREIRA, W.E. Cu e Zn na cultura do sorgo cultivado em três classes de solos. I. Crescimento vegetativo e produção. Revista Brasileira de Engenharia Agrícola e Ambiental. v. 13, p. 125-130, 2009.

SILVA, M DE A., JERONIMO, E.M.; LÚCIO, A.D. Perfilhamento e produtividade de canade-açúcar com diferentes alturas de corte e épocas de colheita. Pesquisa Agropecuária Brasileira, v. 43, p. 979-986, 2008.

SILVA, M. A.; CATO, S. C.; COSTA, A. G. F. Produtividade e qualidade tecnológica da soqueira de cana-de-açúcar submetida à aplicação de biorregulador e fertilizantes líquidos. Ciência Rural, v.40, p.774-780, 2010.

SILVA, A.P.M.; BONO, J.A.M.; PEREIRA, F.A.R. Aplicação de vinhaça na cultura da canade-açúcar: Efeito no solo e na produtividade de colmos. Revista Brasileira de Engenharia Agrícola e Ambiental, v. 18, p. 38-43, 2014.

SILVA, M.A.; ARANTES, M.T.; RHEIN, A.F.L.; GAVA, G.J.C.; KOLLN, O.T. Potencial produtivo da cana-de-açúcar sob irrigação por gotejamento em função de variedades e ciclos. Revista Brasileira de Engenharia Agrícola e Ambiental, v.18, p. 241-249, 2014.

VASCONCELOS, A.C.M de; CASAGRANDE, A.A. Fisiologia do Sistema Radicular. In: DINARDO-MIRANDA, L.L.; VASCONCELOS, A.C.M.; LANDELL, M.G.A. Cana-deAçúcar, Instituto Agronômico. Campinas. $1^{a}$ Reimpressão. 2010, p. 79-97. 
III. CAPITULO 2

PRODUTIVIDADE DA CANA-DE-AÇÚCAR EM LATOSSOLOS FÉRRICOS NA REGIÃO DE GOIATUBA, GO 


\title{
III. CAPITULO 2 - PRODUTIVIDADE DA CANA-DE-AÇÚCAR EM LATOSSOLOS FÉRRICOS NA REGIÃO DE GOIATUBA, GO
}

\begin{abstract}
RESUMO
A produtividade da cana-de-açúcar é influenciada por vários atributos dos solos, dentre eles, atributos morfológicos, químicos e físico-hídricos. O objetivo deste trabalho foi avaliar a produtividade da variedade de cana-de-açúcar RB867515 cultivada em Latossolos Férricos distintos em relação à caracterização morfológica, química e físico hídrica, em três épocas dos anos de 2014 e 2015, na usina Goiasa, Goiatuba, GO, localizada no Sul do Estado de Goiás. Os solos foram avaliados em pares de classes de Latossolos Férricos morfológica e quimicamente distintos sendo o primeiro representado por Latossolo Vermelho Acriférrico petroplíntico e Latossolo Vermelho Acriférrico típico, avaliados quanto à diferenciação morfológica; e o segundo par constituído por Latossolo Vermelho Acriférrico típico e Latossolo Vermelho Distroférrico típico interpretados pela variação das propriedades químicas. Todos os solos estudados apresentam composição textural muito argilosa. Por meio de trincheiras foram realizadas caracterização morfológica completa e coleta de amostras para realização de análises física (granulometria) e química (complexo sortivo). Foram também avaliadas as características físico-hídricas mediante amostras indeformadas de sete profundidades ao longo dos perfis pedológicos, para a análise da densidade do solo (Ds), volume total de poros (VTP), macro, meso e microporosidade e a curva de retenção de água nos solos, para o cálculo da água disponível (AD). A cultura da cana-de-açúcar teve seu potencial hídrico foliar estimado mediante utilização da bomba de Scholander. Os dados foram analisados estatisticamente pelo teste $t$ de comparação de médias. Não houve diferença na $\mathrm{AD}$ entre os solos avaliados. No primeiro par de solos avaliados, a presença de horizonte concrecionário no LVwf petroplíntico, afetou positivamente a produtividade da cana-deaçúcar colhida no mês de agosto de 2014, otimizada pela ocorrência de alta precipitação pluviométrica, atípica, no mês de julho deste ano. A avaliação do potencial hídrico foliar demonstrou maior conteúdo de água nas folhas da cana-de-açúcar cultivada no solo com horizonte concrecionário.
\end{abstract}

Palavras-chave: Morfologia, horizonte concrecionário, caráter ácrico, caráter distrófico, atributos físico hídricos, potencial hídrico foliar. 


\title{
III. CHAPTER 2 - PRODUCTIVITY OF SUGARCANE IN FERRIC LATOSOLS IN THE REGION OF GOIATUBA, GO
}

\begin{abstract}
The productivity of sugarcane is influenced by several attributes of the soils, among them, morphological, chemical and physical-hydric attributes. The aim of this study was to evaluate the productivity of the variety of sugarcane RB867515, grown in distincts Ferric Latosols in relation to the morphological, chemical and physical-hydric characterization, in three seasons of the years 2014 and 2015, in the Usina Goiasa, Goiatuba, GO, located in the southern of Goiás state. The soils were evaluated in pairs of classes of Ferric Latosols, morphologically and chemically distincts, with the first represented by petroplinthic Acriferric Red Latosol and typical Acriferric Red Latosol, evaluated for morphological differentiation; and the second pair was constituted by typical Acriferric Red Latosol and typical Dystroferric Red Latosol, interpreted by the variation of the chemical characterization. All the studied soils presented a very clayey textural composition. Through trenches, a full morphological characterization and samples collection for physical (granulometry) and chemical (sorption complex) analysis were made. The physical-hydric characteristics were also evaluated through undisturbed samples of seven depths along the pedological profiles, for the analysis of soil density (Ds), total pore volume (VTP), macro, meso and microporosity, and water retention curve in the soils, for the calculation of the available water (AD). The culture of sugarcane had its leaf water potential estimated by the use of the Scholander pump. The data were statistically analyzed by the t-test of comparison of averages. There was no difference in AD between the evaluated soils. In the first pair of evaluated soils, the presence of concretionary horizon in petroplinthic LVwf positively affected the productivity of sugarcane harvested in August 2014, optimized by the occurrence of high rainfall, atypical, in July of that year. The evaluation of the leaf water potential showed higher content of water in the leaves of sugarcane cultivated in the soil with concretionary horizon.
\end{abstract}

Key words: Morphology, concretionary horizon, acric character, dystrophic character, physical- hydric attributes, leaf water potential. 


\section{III.1. INTRODUÇÃO}

A grande extensão territorial brasileira associada à condição pedoclimática favorável presente na maior parte do país, destaca o Brasil no cenário agrícola mundial (Marin e Nasiff, 2013). De acordo com o senso da safra 2016/2017 da Companhia Nacional de Abastecimento (CONAB, 2016), as áreas destinadas à produção de cana-de-açúcar ocupam uma área superior a 9,07 milhões de hectares, sendo o Brasil o maior produtor mundial de açúcar e o segundo maior na produção de etanol (Marin e Nasiff, 2013).

Estudos que avaliam o efeito das características morfológicas dos solos na produtividade das culturas são escassos. Já os trabalhos que consideram alguns atributos dos solos como fatores de produção são mais frequentes, podendo-se citar o estudo de Santos et al. (2008) que utilizaram a textura dos solos como parâmetro de produtividade para a cultura da soja em lavouras dos municípios de Dourados, MT e Camapuã, MS; e Cunha et al. (2000) que concluíram que a grande predominância de microporos no horizonte de subsuperfície dos Argissolos afetaram de maneira negativa o desenvolvimento do sistema radicular e a produtividade da cultura da seringueira cultivada no município de Oratório, MG.

Com relação à disponibilidade de água no solo, Mesquita et al. (2007) concluíram que a ausência no ambiente natural de árvores de Araticum em Latossolos petroplínticos, foi devido ao grande acúmulo de água no solo em várias localidades do Estado de Goiás. Já Campos et al. (2010) avaliaram as características físico-hídricas de Latossolos Vermelhos (LVs) e Latossolos Vermelho-Amarelos petroplínticos (LVAs) do Distrito Federal e concluíram a maior predominância da vegetação de Cerrado e Cerradão nos LVs, e Cerrado strictu senso e Campo Cerrado nos LVAs petroplínticos em função da maior oscilação do lençol freático em profundidade.

O trabalho de Papa et al. (2011) da avaliação da qualidade de Latossolos Vermelhos e Vermelho-Amarelos petroplínticos do Distrito Federal, concluíram que a presença de horizonte concrecionário em subsuperfície pode afetar o potencial do solo para fins agrícolas de maneira negativa no período chuvoso, em função da saturação de água nos solos.

Entretanto, Pádua Junior et al. (2007), ao avaliar o desenvolvimento da variedade de cana-de-açúcar SP81-3250 em Latossolo Vermelho Distroférrico e Cambissolo Háplico Tb Distrófico petroplíntico álico na região de Itumbiara, Estado de Goiás, concluíram que a presença do horizonte concrecionário permitiu o melhor aproveitamento de água para o crescimento e desenvolvimento da cana-de-açúcar, apesar da maior limitação química desse solo. 
Ferreira et al. (2007) estudaram o surgimento da vegetação nativa em Campinas, SP, com base na disponibilidade hídrica das classes de solo. Um dos fatores que os autores correlacionaram para o desenvolvimento da vegetação nativa de Cerrado em áreas de Latossolos foi a baixa disponibilidade de água. O predomínio de Argissolos e Nitossolos com elevada disponibilidade hídrica nos horizontes B textural e B nítico, respectivamente, decorrente da distinta distribuição de poros entre os horizontes de superfície e subsuperfície nos Argissolos e a restrita comunicação entre os poros devido à estrutura prismática no horizonte B nítico dos Nitossolos, possibilitaram o surgimento das matas nativas (Floresta tropical subcaducifólia).

Na Região do Cerrado Brasileiro, os Latossolos são os solos predominantes (Adámoli et al. 1985; Correia et al. 2002). Esses solos apresentam avançado grau de intemperismo, geralmente com caráter químico distrófico, sendo muitas vezes ácricos. No levantamento de solos do Estado de São Paulo, Ministério da Agricultura (1960), foram relatados em descrições de perfis de solos sob vegetação do Cerrado valores de $\Delta \mathrm{pH}$ positivo no subsolo.

Em relação às características físico-hídricas, a curva de retenção de água nos solos ácricos, mostra-se semelhante a dos solos distróficos (Reatto et al., 2007), o que dificulta considerar este atributo físico como limitante para a evolução de culturas para os solos ácricos. Porém, por meio da observação das culturas no campo, cultivadas nesses solos, verifica-se baixo desenvolvimento da cultura da cana-de-açúcar, provavelmente pela falta de água (Demattê e Demattê, 2009), corroborando com os estudos conduzidos por Alleoni e Camargo (1994), que relataram a baixa capacidade de água disponível em Latossolos ácricos da região norte de São Paulo, devido à forte microagregação da fração argila em subsuperfície.

Ressalta-se que a cana-de-açúcar, em função do seu extenso sistema radicular, é uma cultura altamente dependente das características físicas subsuperficiais dos solos. De acordo com Dias et al. (1999), na região noroeste do Estado de São Paulo, a elevada água disponível presente em horizonte subsuperfícial de Argissolos Vermelho-Amarelos Eutróficos favoreceu a produtividade da cana-de-açúcar, em função da descontinuidade de poros entre os horizontes de superfície e de subsuperfície.

O potencial hídrico foliar é considerado o melhor método para avaliação do status de água na planta e integra a água disponível ao longo do perfil do solo absorvida pelo sistema radicular e pela demanda evapotranspiritiva demonstrando o dinamismo do movimento da água no sistema solo-planta-atmosfera. Segundo Pincelli (2010), a medida de água na planta indica ser uma importante ferramenta na avaliação do grau de estresse hídrico entre as 
variedades de cana-de-açúcar. Rodolfo Júnior (2015) e Silva et al. (2014), relatam diferenças no aproveitamento de água pela cana-de-açúcar mediante mecanismos estomáticos específicos para cada variedade.

Diante deste cenário, este trabalho teve como objetivo avaliar a produtividade da variedade de cana-de-açúcar RB867515 cultivada em três épocas do ano (maio, agosto e outubro) nos anos de 2014 e 2015 em Latossolos Férricos distintos em relação à caracterização morfológica, química e físico hídrica, na usina Goiasa, município de Goiatuba, GO. 


\section{III.2. MATERIAL E MÉTODOS}

\section{III.2.1. Caracterização e seleção das áreas de estudo}

O presente estudo foi realizado em áreas de produção de cana-de-açúcar da Usina Goiasa, localizada no munícipio de Goiatuba, Estado de Goiás.

O clima da região, segundo a classificação de Köppen, é do tipo Aw, classificado como tropical úmido, com duas estações bem definidas, úmida no verão, com chuvas concentradas nos meses de dezembro a março e seca no inverno, com a precipitação média anual de $1350 \mathrm{~mm}$ (Climatempo, 2016) e a temperatura média no mês mais frio é superior a $18^{\circ} \mathrm{C}$ (Adámoli et al., 1985). Na região do estudo, os Latossolos são os solos predominantes (Oliveira et al., 2010), geralmente desenvolvidos a partir de litologias basálticas (Oliveira et al., 2012). Esses solos apresentam avançado grau de intemperismo, geralmente profundos, bem drenados, ácidos, com baixa fertilidade natural, geralmente com caráter químico distroférrico ou acriférrico. Associados aos Latossolos ocorrem grandes extensões de solos com horizontes concrecionários (Lopes, 1984; Resende et al., 2007).

Para a seleção das áreas para o estudo foi utilizado o banco de dados da Usina Goiasa. Nesse banco de dados, as áreas cultivadas com cana-de-açúcar foram divididas em unidades produtivas (UPs), com informações sobre classes de solo, ambientes de produção, variedades, sistemas de cultivo (orgânico ou convencional), presença ou ausência de irrigação ou fertirrigação (utilização de vinhaça), dentre outras informações de manejo.

O principal critério adotado na seleção das áreas de estudo foram as classes de solos, consideradas representativas da produção de cana-de-açúcar nesta usina, região Sul do Estado de Goiás. As classes de solos foram selecionadas para o estudo nas UPs e por meio dos mapas pedológicos disponíveis no banco de dados da Usina Goiasa.

Foram selecionados um Latossolo Vermelho Distroférrico (LVdf), dois Latossolos Vermelhos Acriférricos típicos (LVwf) e um Latossolo Vermelho Acriférrico petroplíntico, todos com composição textural muito argilosa, originados de rocha ígnea basáltica, da formação Serra Geral (Oliveira et al., 2012; Machado et al., 2009). Essas classes de solos foram consideradas representativas na Usina avaliada.

Os solos foram avaliados em pares, com intuito de avaliar comparativamente a influência das suas características morfológicas, químicas e físico-hídricas na produtividade da cultura da cana-de-açúcar. O primeiro par de solos (pontos 1 (P1) e 2 (P2)) foram descritos e classificados como Latossolos Vermelhos Ácriférricos, sendo que o P1 apresenta horizonte concrecionário a partir de $120 \mathrm{~cm}$ de profundidade, caracterizando LVwf petroplíntico e o P2 
classificado como LVwf típico. O segundo par de solos (pontos 3 (P3) e 4 (P4)) são distintos quimicamente sendo o P3 classificado como Latossolo Vermelho Acriférrico típico e o P4 como Latossolo Vermelho Distroférrico típico (Figura 5).

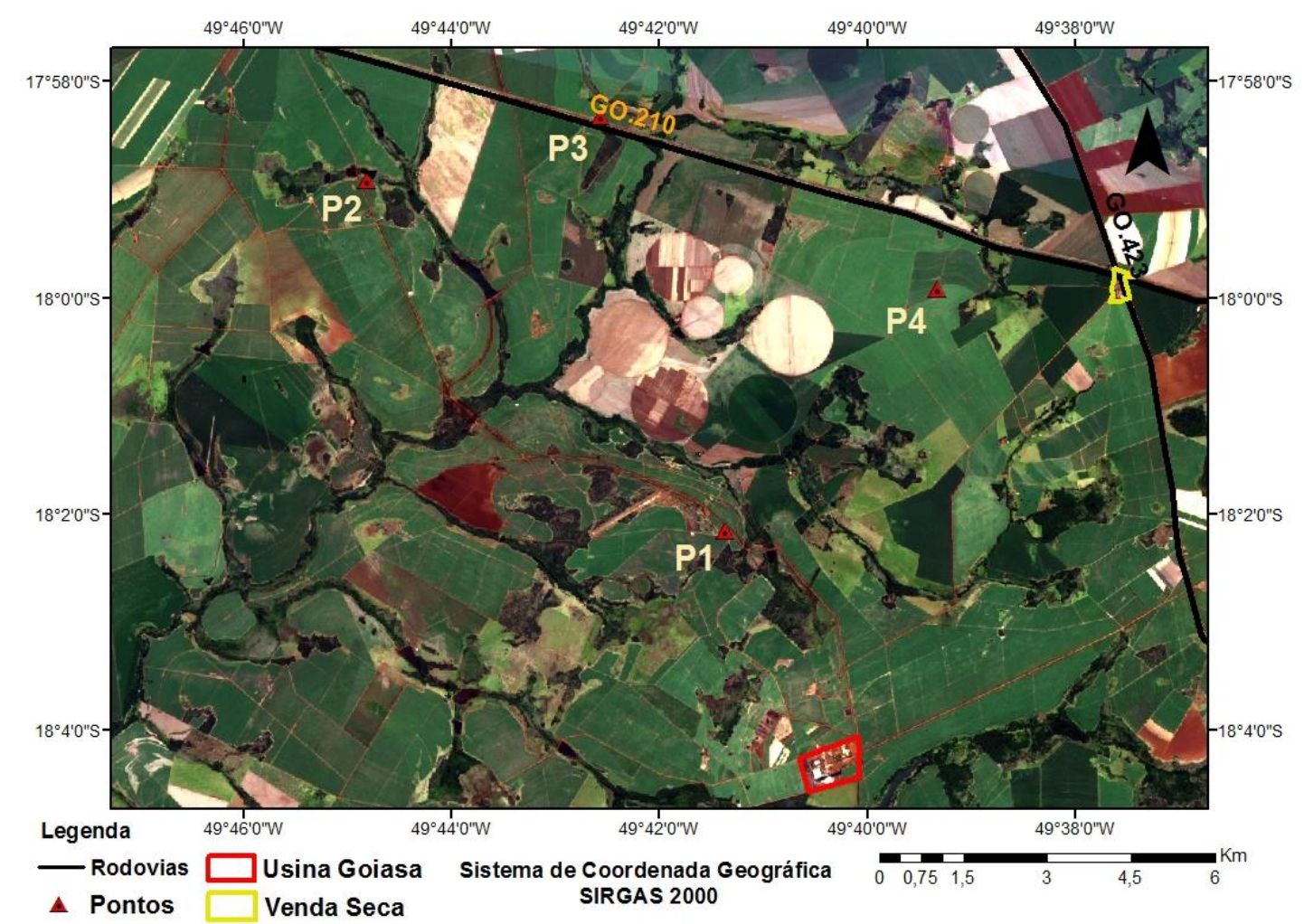

Figura 5. Localização dos pontos dos solos estudados na Usina Goiasa, Goiatuba, GO.

Em cada ponto delimitou-se para amostragens do solo e avaliação da planta área de 10 linhas cultivadas com cana-de-açúcar, com espaçamento entrelinhas de 1,5 m, e 15 m lineares de comprimento, totalizando $225 \mathrm{~m}^{2}$. Essas áreas foram demarcadas a 20 metros a partir da estrada/carreador de cada talhão, com bordaduras laterais constituídas por duas linhas de cana-de-açúcar, e ao fundo, 20 metros de bordadura.

Os pontos dos perfis dos solos e suas áreas de influência foram devidamente georreferenciadas com GPS GARMIN MAP 60X (Figura 5). Além das classes de solos, as áreas de influência apresentavam outras variáveis uniformes, ou seja; cultivadas com a variedade de cana-de-açúcar RB867515, em sistema de plantio convencional sem aplicação de vinhaça e sob manejo em sequeiro, com desenvolvimento relativo ao final da segunda colheita, visto que a literatura indica maior influência do horizonte de subsuperfície dos solos a partir da terceira colheita agrícola (Landell et al., 2003). 
A variedade RB867515 foi selecionada por ser uma das mais cultivadas na região Sul do Estado de Goiás e por apresentar ciclo médio-tardio, com a colheita realizada durante os períodos mais secos do ano, fator este importante para as avaliações do presente trabalho.

\section{III.2.2. Avaliação do desenvolvimento da cultura}

A implantação da cana-de-açúcar nas áreas selecionadas para o estudo seguiu procedimentos normalmente adotados pela Usina Goiasa, que consistem em subsolagem seguida de gradagem pesada para incorporação de 4,00 a 5,00 t ha ${ }^{-1}$ de calcário dolomítico. $\mathrm{Na}$ cana planta foram aplicados $30 \mathrm{~kg} \mathrm{ha}^{-1}$ de $\mathrm{N}, 170 \mathrm{~kg} \mathrm{ha}^{-1}$ de $\mathrm{P}_{2} \mathrm{O}_{5}$ e $140 \mathrm{~kg}$ de $\mathrm{K}_{2} \mathrm{O}$. Nas soqueiras foram aplicados anualmente, sobre a palhada na superfície do solo, 80 a $100 \mathrm{~kg} \mathrm{ha}^{-1}$ de $\mathrm{N}$ e 96 a $120 \mathrm{~kg} \mathrm{ha}^{-1}$ de $\mathrm{K}_{2} \mathrm{O}$.

\section{III.2.3. Avaliação da produtividade da cana-de-açúcar}

Foi realizada a pesagem da cana-de-açúcar nas quatro áreas de estudo, para a avaliação da produtividade, em toneladas de colmos por hectare $(\mathrm{TCH})$, em diferentes épocas de corte (maio, agosto e outubro) correspondentes ao início, meio e final de colheita do terceiro e quarto cortes dos anos de 2014 e 2015. Foi realizada mediante colheita de $5 \mathrm{~m}$ lineares de cana-de-açúcar, em triplicatas e posteriormente pesadas no campo em balança tipo gancho da marca Kern, modelo HCB 99k50 com capacidade de pesagem de 99 kg e leitura mínima de 50 g.

\section{III.2.4. Potencial hídrico foliar}

O potencial hídrico foliar da cultura da cana-de-açúcar nas áreas em estudo foi avaliado com a utilização da bomba de Scholander, no período de três a cinco horas da manhã (período considerado como potencial hídrico de base) do mês de agosto dos anos de 2014 e 2015. Foram coletadas dez folhas classificadas segundo o sistema Kuijper como +1 (Scarpari e Beauclair, 2010). Como as amostras foram coletadas no mês de agosto, considerado período de estresse hídrico na região, o critério para a escolha da folha a ser amostrada foi a ausência de senescência ou qualquer dano físico na área foliar. A coleta foi realizada em plantas dispostas em diferentes posições nas quatro áreas avaliadas. As folhas foram cortadas em seu terço médio, e a nervura central foi descartada, onde as dimensões da amostra final do limbo foliar foram de 1,0 cm de largura por $20 \mathrm{~cm}$ de comprimento. As folhas foram colocadas na câmera da bomba de Scholander, bem vedadas para evitar a perda da pressão. A válvula para 
a liberação do gás nitrogênio foi acionada e a leitura determinada no surgimento de uma gotícula na superfície do limbo foliar exposto (Scholander, 1965).

\section{III.2.5. Caracterização morfológica, química e físico-hídrica dos solos estudados}

A descrição morfológica dos solos foi realizada com abertura de trincheiras nos pontos previamente selecionados nas quatro áreas do estudo, em que se adotou a metodologia descrita por Santos et al. (2013).

Após a identificação dos horizontes e sub-horizontes nas trincheiras foram coletadas amostras deformadas para a determinação química do complexo sortivo ( $\mathrm{pH}$, matéria orgânica, macro e micronutrientes) e para a caracterização granulométrica, conforme Embrapa (1997). Os principais óxidos constituintes $\left(\mathrm{SiO}_{2}, \mathrm{Al}_{2} \mathrm{O}_{3}\right.$ e $\left.\mathrm{Fe}_{2} \mathrm{O}_{3}\right)$ e as relações $\mathrm{Ki}$ e $\mathrm{Kr}$ foram determinados por meio de análise ao ataque sulfúrico (Embrapa, 1997).

As demais análises físicas foram coletadas a $20 \mathrm{~cm}$ de ambos os lados de duas linhas de plantio da cultura, nas seguintes profundidades: $0-15 \mathrm{~cm} ; 15-30 \mathrm{~cm} ; 30-45 \mathrm{~cm} ; 45-60 \mathrm{~cm}$; $60-90 \mathrm{~cm} ; 90-150 \mathrm{~cm}$ e $150-210 \mathrm{~cm}$, em triplicatas, por meio de amostras indeformadas em anéis metálicos de $5 \mathrm{~cm}$ de altura e $5 \mathrm{~cm}$ de diâmetro com auxílio do amostrador de Uhland, para caracterização da densidade do solo e volume total de poros, conforme metodologia descrita em Embrapa (1997).

A granulometria dos solos foi determinada pelo método da pipeta conforme proposto por Embrapa (1997).

A quantificação de poros do solo por tamanho seguiu modificações de equação 1 proposta por Bouma (1991):

$$
\mathrm{D}=(4 \sigma \operatorname{Cos} \theta) / \psi \mathrm{m}
$$

Sendo:

$\mathrm{D}=$ diâmetro do poro $(\mu \mathrm{m})$;

$\sigma=$ tensão superficial da água $\left(73,43 \mathrm{kPa} \mu \mathrm{m}\right.$ a $\left.20^{\circ} \mathrm{C}\right)$;

$\theta=$ ângulo de contato entre o menisco e a parede do tubo capilar (considerado como 0 ); e $\psi \mathrm{m}=$ tensão de água no solo $(\mathrm{kPa})$.

Foi adotado o critério utilizado por Koorenvaar et al. (1983), que considera como limite $100 \mu \mathrm{m}$ entre macros e mesoporos e $30 \mu \mathrm{m}$ entre meso e microporos. 
Para obtenção dos teores de água disponível, foi realizada a determinação da curva de retenção de água dos solos no laboratório de Física do Solo da EMBRAPA/CPAC, mediante utilização da centrífuga, conforme metodologia descrita por Freitas Junior e Silva (1984). As amostras indeformadas em anéis foram previamente saturadas em água por um dia e submetidas a rotações da centrífuga por um período de 30 minutos. As rotações aplicadas foram: 220; 380; 540; 700; 1300; 1700; 2200 e 8500 rpm, correspondentes às tensões de 10; 30; 60; 100; 330; 600; 1000; e $15000 \mathrm{hPa}$. Para cada classe de solo foi obtida a curva de retenção de água no solo (teor de água volumétrico, em $\mathrm{cm}^{3} \mathrm{~cm}^{-3}$ em função da tensão mátrica, em hPa). Os dados obtidos foram ajustados ao modelo proposto por van Genuchten (1980) por meio do Software Soil Water Retention Curve (SWRC, version 2.00) (Dourado Neto et al. 2000). 


\section{III.3. RESULTADOS E DISCUSSÃO}

\section{III.3.1. Características dos solos estudados}

\section{Caracterização morfológica}

Mediante análise morfológica, identificou-se a plintita e petroplintita no P1 (LVwf petroplíntico) (Tabela 6).

Tabela 6. Descrição morfológica dos perfis de solos LVwf petroplíntico, LVwf, LVwf e LVdf estudados nos pontos 1 a 4, respectivamente, na Usina Goiasa, Goiatuba, GO.

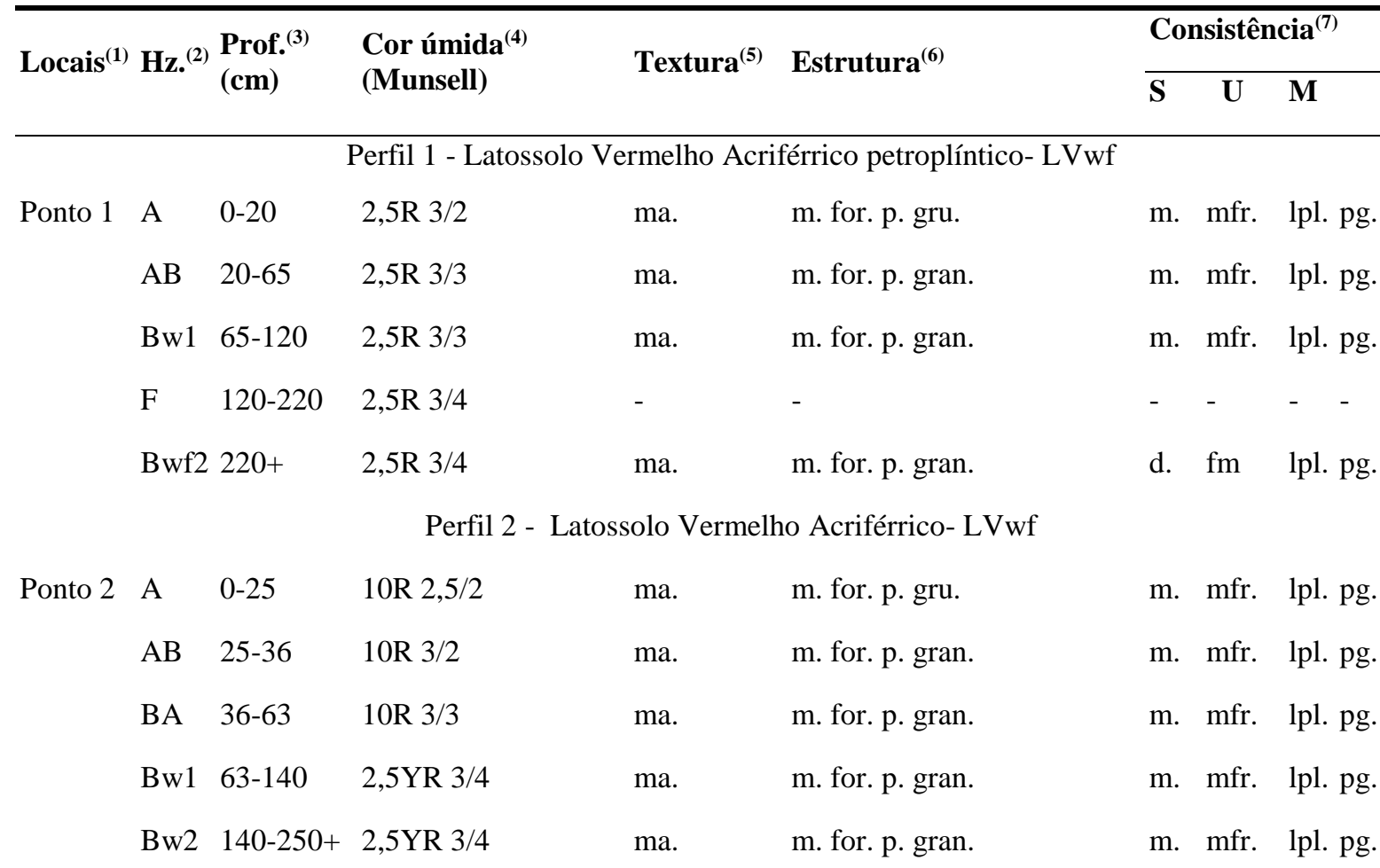

Perfil 3 - Latossolo Vermelho Acriférrico- LVwf

\begin{tabular}{|c|c|c|c|c|c|c|}
\hline \multirow[t]{3}{*}{ Ponto 3} & A & $0-50$ & $10 \mathrm{R} 2,5 / 2$ & ma. & m. for. p. gru. & m. mfr. lpl. pg. \\
\hline & Bw1 & $50-78$ & 10R $2,75 / 2$ & ma. & m. for. p. gran. & m. mfr. lpl. p \\
\hline & Bw2 & $78-250+$ & $10 \mathrm{R} 3 / 3$ & ma. & m. for. p. gran. & m. mfr. \\
\hline
\end{tabular}

Perfil 4 - Latossolo Vermelho Distroférrico- LVdf

\begin{tabular}{|c|c|c|c|c|c|c|}
\hline \multirow[t]{4}{*}{ Ponto 4} & A & $0-25$ & $10 \mathrm{R} 2,75 / 2$ & ma. & m. for. p. gru. & m. mfr. lpl. pg. \\
\hline & BA & $25-48$ & 10R $2,75 / 3$ & ma. & m. for. p. gran. & m. mfr. lpl. p \\
\hline & Bw1 & $48-150$ & $10 \mathrm{R} 3 / 3$ & ma. & m. for. p. gran. & m. mfr. lpl. p \\
\hline & Bw2 & $150-250+$ & $10 \mathrm{R} 3 / 4$ & ma. & m. for. p. gran. & $\mathrm{m}$. \\
\hline
\end{tabular}

\footnotetext{
${ }^{(1)}$ Locais de avaliação, ${ }^{(2)}$ Horizonte, ${ }^{(3)}$ Profundidade, ${ }^{(4)}$ matiz/valor/croma, ${ }^{(5)}$ Textura: ma.: muito argilosa,

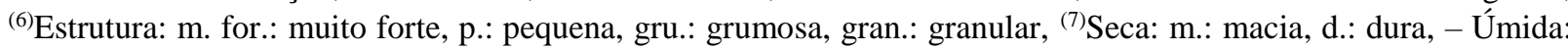
mfr.: muito friável, fr.: friável, fm.: firme, - Molhada: lpl.: ligeiramente plástica, pg.: pegajosa.
} 
Todos os perfis apresentam matiz vermelho, condizente com elevada relação hematita/goethita, disponibilizado pelas rochas basálticas de origem pertencentes à Formação Serra Geral. Campos et al. (2010) descreveram a cor vermelho-amarela em Latossolos Ácricos Mesoférricos do Distrito Federal, originados a partir de ardósia do Grupo Paranoá, com presença de horizonte concrecionário em subsuperfície.

Provavelmente, o elevado teor de $\mathrm{Fe}_{2} \mathrm{O}_{3}$ do material de origem dos solos estudados formado por basaltos da Formação Serra Geral, dificultou a estabilização da goethita em relação à hematita, que proporcionaria mudança de cor do horizonte de subsuperfície, devido à oscilação do lençol freático proporcionada pela presença do horizonte concrecionário. Soares et al. (2005) ao estudar as características físicas e morfológicas de Latossolos Vermelhos formados por rochas basálticas em áreas de citrus e cana-de-açúcar no município de Bariri, Estado de São Paulo, concluíram que o matiz foi predominantemente influenciada pela hematita oriunda de alterações das rochas basálticas de origem.

A presença de estrutura granular nos quatro solos avaliados, provavelmente afetou de forma negativa a retenção e disponibilidade de água. Adámoli et al. (1985) descrevem os Latossolos do Cerrado como solos muito profundos, bem drenados e com elevada porosidade total, fator esse associado à baixa disponibilidade de água para as plantas.

Severiano et al. (2010) avaliaram o efeito da estrutura na resistência à compactação de um Latossolo Vermelho-Amarelo e de um Cambissolo Háplico, onde a estrutura granular do Latossolo com grande macroporosidade, foi responsável pela maior susceptibilidade à compactação, quando comparado ao Cambissolo Háplico com estrutura em blocos.

\section{Caracterização química - Complexo sortivo}

A baixa retenção de cátions ( $\mathrm{RC}$ ), inferior a $1,5 \mathrm{cmol}_{\mathrm{c}} \mathrm{kg}^{-1}$ argila e $\mathrm{pH}$ em $\mathrm{KCl} \geq$ a 5,0; e ou $\Delta \mathrm{pH}$ positivo ou nulo, critérios adotados para a classificação de solos com o caráter ácrico (Embrapa, 2013) foi diagnóstico para os pontos P1, P2 e P3 (Tabela 7), indicando características de solos altamente intemperizados. Esses dados concordam com os resultados de Reatto et al. (2007) que obteve resultados semelhantes em Latossolos ácricos em diferentes localidades no Brasil.

Na Usina Goiasa, verificou-se grande ocorrência de Latossolos com caráter acriférrico, revelando alto grau de intemperismo desses solos, favorecido pelo material basáltico de origem, pelas condições de relevo aplainadas e condições climáticas favoráveis. De acordo com Müller et al. (1993), Renne et al. (1996); Ernesto et al. (1999), Thiede e Vasconcelos (2008), os dados paleomagnéticos e datações ${ }^{40} \mathrm{Ar} /{ }^{39} \mathrm{Ar}$, sugerem que a atividade vulcânica na 
região sul de Goiás é mais recente em relação à da região sudeste e sul do Brasil, onde a forte influência do clima mais ativo desta região, proporcionou a elevada intemperização dos solos na região estudada.

Tabela 7. Análises químicas dos perfis de solos 1, 2, 3 e 4 estudados na Usina Goiasa, Goiatuba, GO.

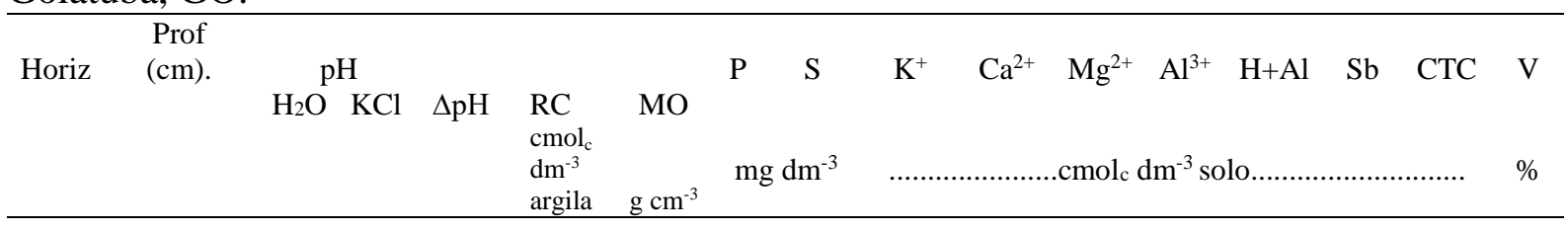

P1 -Latossolo Vermelho Acriférrico petroplíntico

$\begin{array}{llrrrrrrrrrrrrrrl}\text { A } & 0-20 & 6,1 & 5,4 & -0,7 & 5,03 & 49 & 1 & 26,0 & 0,22 & 2,8 & 0,5 & 0,0 & 3,08 & 3,52 & 6,60 & 53 \\ \text { AB } & 20-65 & 5,9 & 5,5 & -0,4 & 2,01 & 27 & 1 & 56,0 & 0,21 & 0,9 & 0,3 & 0,0 & 2,49 & 1,41 & 3,90 & 36 \\ \text { Bw1 } & 65-120 & 6,5 & 6,3 & -0,2 & 0,40 & 18 & 1 & 2,0 & 0,08 & 0,1 & 0,1 & 0,0 & 1,82 & 0,28 & 2,10 & 13 \\ \text { F } & 120-220 & 6,4 & 6,5 & 0,1 & 0,37 & 8 & 1 & 16,0 & 0,06 & 0,1 & 0,1 & 0,0 & 1,64 & 0,26 & 1,90 & 14 \\ \text { Bwf2 } & 220+ & 6,6 & 6,5 & -0,1 & 0,31 & 10 & 1 & 8,0 & 0,02 & 0,1 & 0,1 & 0,0 & 1,64 & 0,22 & 1,86 & 12\end{array}$

P2 - Latossolo Vermelho Acriférrico típico

$\begin{array}{llrrrrrrrrrrrrrrl}\text { A } & 0-25 & 5,5 & 4,6 & -0,9 & 3,93 & 43 & 3 & 40,0 & 0,25 & 2,1 & 0,3 & 0,1 & 1,82 & 2,65 & 4,47 & 59 \\ \text { AB } & 25-36 & 5,6 & 4,6 & -1,0 & 0,93 & 29 & 1 & 44,0 & 0,05 & 0,5 & 0,1 & 0,0 & 2,24 & 0,65 & 2,89 & 23 \\ \text { BA } & 36-63 & 5,4 & 5,0 & -0,4 & 0,90 & 25 & 1 & 4,0 & 0,03 & 0,4 & 0,1 & 0,1 & 1,82 & 0,53 & 2,35 & 23 \\ \text { Bw1 } & 63-140 & 5,5 & 5,7 & 0,2 & 0,31 & 15 & 1 & 2,0 & 0,02 & 0,1 & 0,1 & 0,0 & 1,82 & 0,22 & 2,04 & 11 \\ \text { Bw2 } & 140-250 & 6,2 & 6,2 & 0,0 & 0,30 & 12 & 1 & 2,0 & 0,01 & 0,1 & 0,1 & 0,0 & 1,64 & 0,21 & 1,85 & 11\end{array}$

P3 - Latossolo Vermelho Acriférrico típico

\begin{tabular}{|c|c|c|c|c|c|c|c|c|c|c|c|c|c|c|c|}
\hline A & $0-50$ & 6,6 & 5,7 & $-0,9$ & 5,40 & 37 & 1 & 26,0 & 0,08 & 3,0 & 0,7 & 0,0 & 2,02 & 3,78 & 5,80 \\
\hline Bw1 & $50-78$ & 6,1 & 5,8 & $-0,3$ & 0,74 & 24 & 1 & 4,0 & 0,02 & 0,3 & 0,2 & 0,0 & 1,82 & 0,52 & 2,34 \\
\hline Bw2 & $78-250^{+}$ & 6,3 & 6,2 & $-0,1$ & 0,31 & 10 & 1 & 2,0 & 0,02 & 0,1 & 0,1 & 0,0 & 1,64 & 0,22 & 1,86 \\
\hline
\end{tabular}

P4 - Latossolo Vermelho Distroférrico típico

\begin{tabular}{llrrrrrrrrrrrrrrr} 
A & $0-25$ & 6,8 & 6,0 & $-0,8$ & 10,31 & 43 & 5 & 8,0 & 0,12 & 5,0 & 2,1 & 0,0 & 1,64 & 7,22 & 8,86 & 82 \\
BA & $25-48$ & 6,8 & 6,0 & $-0,8$ & 6,34 & 32 & 1 & 4,0 & 0,04 & 3,6 & 0,8 & 0,0 & 1,64 & 4,44 & 6,08 & 73 \\
Bw1 & $48-150$ & 6,2 & 5,6 & $-0,6$ & 1,60 & 13 & 1 & 14,0 & 0,02 & 0,6 & 0,5 & 0,0 & 2,24 & 1,12 & 3,36 & 33 \\
Bw2 & $150-250^{+}$ & 5,7 & 5,8 & 0,1 & 0,73 & 8 & 1 & 2,0 & 0,01 & 0,3 & 0,2 & 0,0 & 2,02 & 0,51 & 2,53 & 20 \\
\hline
\end{tabular}
pH KCl - 1 mol.L ${ }^{-1}$, P e K - Melihch 1(HCl 0,05M + $\mathrm{H}_{2} \mathrm{SO}_{4} 0,0125 \mathrm{~mol} \mathrm{~L}^{-1} ; \mathrm{M} . \mathrm{O}$ - Walkley \& Black; Ca, $\mathrm{Mg}$, $\mathrm{Al}$ - $\mathrm{KCl} 1 \mathrm{~mol} \mathrm{~L}^{-1}$ e $\mathrm{H}+\mathrm{Al}$ - acetato de cálcio $0,5 \mathrm{~mol} \mathrm{~L}^{-1}, \mathrm{~S}-$ Fosfato Monocálcio em ácido acético

De acordo com Cury e Franzmeier (1984) os solos predominante no município de Itumbiara, Sul do Estado de Goiás, são os Latossolos Vermelhos Distroférricos e Acriférricos oriundos da rocha basálticas, em condições de clima mais ativo, com valores médios de precipitação pluviométrica de $1350 \mathrm{~mm}$ anuais (Climatempo, 2016). 
Oliveira et al. (2010) ao estudar Latossolos Vermelhos Acriférricos (LVwf), Argissolos Vermelhos Eutróficos (PVe), Nitossolos Vermelhos Eutroférricos (NVef) e Neossolos Quartzarênicos (RQ), relataram que os Latossolos Vermelhos Acriférricos apresentaram baixo potencial químico, cujo teor de bases trocáveis $(\mathrm{S})$, foi inferior ao obtido no Neossolo Quartzarênico, solo esse de textura arenosa.

Os elevados teores de enxofre no par de solos P1 e P2, indicam provavelmente o efeito residual do gesso aplicado nos solos ácricos. Segundo Raij (2011), em Latossolos ácricos ocorre o processo de adsorção específica dos íons sulfato em função do balanço eletropositivo nos horizontes de subsuperfície dessa classe de solos, tornando os ânions $\left(\mathrm{SO}_{4}{ }^{2-}\right)$ fortemente adsorvidos.

O perfil 4 foi classificado como Latossolo Vermelho Distroférrico, onde os valores de RC até $150 \mathrm{~cm}$ foi limítrofe entre os caracteres ácrico e distrófico (Embrapa, 2013). Abaixo de $150 \mathrm{~cm}$ o caráter químico do solo inverte para ácrico, contudo, o Sistema Brasileiro de Classificação de Solos (SiBCS) (Embrapa, 2013) contempla a distinção entre tais caracteres químicos dentro de $150 \mathrm{~cm}$ da superfície do solo. Cabe salientar, que o caráter ácrico nos pontos estudados inicia-se em diferentes posições nos perfis dos solos (Tabela 7), surgindo abaixo do horizonte de superfície nos perfis 2 e 3, ou ocorrendo em maiores profundidades nos pontos 1 e 4 . A posição do caráter ácrico no perfil do solo pode ter interferido nas propriedades químicas (Raij, 2011; Oliveira et al., 2010; Curi e Franzmeier, 1984) e nos atributos físico-hídricos dos Latossolos (Demattê e Demattê, 2009; Alleoni e Camargo, 1994) e consequentemente no manejo das culturas.

De maneira geral, os teores dos micronutrientes cobre $(\mathrm{Cu})$, ferro $(\mathrm{Fe})$ e manganês (Mn) (Tabela 8) são considerados elevados nos solos estudados (Galrão, 2004). Entretanto, Zanão Júnior et al. (2007) determinaram baixos teores disponíveis dos micronutrientes (Mn e $\mathrm{Cu}$ ) em Latossolo Vermelho Distrófico de textura muito argilosa do município de Uberlândia, Estado de Minas Gerais, demonstrando que o material basáltico apresenta composição química distinta nestes micronutrientes.

A presença de elevados teores de micronutrientes na rocha de origem segundo Lacerda et al. (2002) ocorre devido a concentração nos sesquióxidos de Fe pelos processos pedogenéticos. Dentre os Latossolos avaliados no presente trabalho o elemento Fe exceto no perfil 2, apresentou valores menores no horizonte Ap em relação ao Bw em todas os solos avaliados, acompanhado do $\mathrm{Cu}$, com comportamento semelhante. Entretanto, no perfil 4, o teor de $\mathrm{Cu}$ no perfil do solo foi semelhante, provavelmente pela composição do material de origem basáltico, mais empobrecido em $\mathrm{Cu}$. 
Tabela 8. Análise de micronutrientes dos solos estudados na Usina Goiasa, Goiatuba, GO.

\begin{tabular}{cclrrrrr}
\hline Perfis & \multicolumn{1}{c}{ Solos } & Horizontes & $\mathrm{Zn}^{1}$ & $\mathrm{Fe}^{1}$ & $\mathrm{Mn}^{1}$ & $\mathrm{Cu}^{1}$ & $\mathrm{~B}^{2}$ \\
\hline \multirow{2}{*}{1} & \multirow{2}{*}{ LVwf petroplíntico } & Ap & $2, \ldots 2$ & 31,33 & 44,62 & 3,86 & 0,28 \\
& & $\mathrm{Bw} 1$ & 0,54 & 41,80 & 2,63 & 4,43 & 0,24 \\
\multirow{2}{*}{2} & \multirow{2}{*}{ LVwf típico } & Ap & 0,75 & 45,52 & 71,39 & 2,42 & 0,31 \\
& & Bw & 0,26 & 45,70 & 8,50 & 2,71 & 0,20 \\
\multirow{2}{*}{3} & \multirow{2}{*}{ LVwf típico } & Ap & 0,65 & 34,21 & 63,95 & 6,69 & 0,44 \\
& & Bw2 & 0,33 & 49,09 & 8,46 & 8,59 & 0,23 \\
\multirow{2}{*}{4} & \multirow{2}{*}{ LVdf típico } & Ap & 1,41 & 21,93 & 130,33 & 2,58 & 0,34 \\
& & Bw1 & 0,26 & 50,52 & 12,38 & 2,50 & 0,19 \\
\hline
\end{tabular}

${ }^{1}$ Extrator Mehlich $1 ;{ }^{2}$ Água Quente

De acordo com Biondi et al. (2011) teores naturais dos micronutrientes nos solos ocorrem devido à composição geoquímica do material de origem, por meio de processos pedogenéticos que preservam ou promovem o enriquecimento relativo destes elementos. Os mesmos autores observaram em diferentes regiões fisiográficas do estado de Pernambuco, os maiores teores de micronutrientes em Nitossolos Vermelhos Distroférricos originados de basalto.

\section{Característização química - Ataque sulfúrico}

As análises dos teores de $\mathrm{Si}, \mathrm{Al}, \mathrm{Fe}$, Ti e P expressos na forma de óxidos obtidas pelo ataque sulfúrico confirmaram as características exigidas para a classe dos Latossolos (Embrapa, 2013), em todos os solos estudados, conforme dados expressos na Tabela 9. Os baixos valores de $\mathrm{Ki}, \mathrm{Kr}$ indicam que os solos são muito intemperizados e oxídicos.

O baixo valor do Ki, foi obtido por Ker (1997) para Latossolos da região de Rio Verde Estado de Goiás, demonstrando o avançado grau de intemperismo da mesorregião do Sul Goiano.

$\mathrm{O}$ menor valor de $\mathrm{Kr}$ no solo $\mathrm{P} 1$ foi proporcionado pelo menor teor de $\mathrm{SiO}_{2}$, ou seja, entre os solos avaliados há diferença na composição do material basáltico. Valores de $\mathrm{Kr}$ semelhantes foram descritos por Costa et al. (2014), em Latossolos ácricos originado da rocha Itabirito na região do Quadrilátero Ferrífero, MG.

$\mathrm{O}$ teor de ferro $\left(\mathrm{Fe}_{2} \mathrm{O}_{3}\right)$ nos quatro locais foi superior a $180 \mathrm{~g} \mathrm{~kg}^{-1}$ classificando-os no terceiro nível categórico como férricos (Embrapa, 2013). Valores acima de $180 \mathrm{~g} \mathrm{~kg}^{-1} \mathrm{de}$ $\mathrm{Fe}_{2} \mathrm{O}_{3}$ de solos formados por rochas basálticas da Formação Serra Geral foram relatados por Camargo et al., 2007 em Latossolo Vermelho Distroférrico na região do Triângulo Mineiro e 
por Curi e Franzmeier, (1984) em Latossolo Vermelho Acriférrico de textura muito argilosa da região de Itumbiara, Sul do Estado de Goiás.

Tabela 9. Principais óxidos constituintes dos solos estudados na Usina Goiasa, Goiatuba, GO.

\begin{tabular}{|c|c|c|c|c|c|c|c|c|c|}
\hline Perfis & Solo & $\mathrm{SiO} 2$ & $\mathrm{Al}_{2} \mathrm{O}_{3}$ & $\mathrm{Fe}_{2} \mathrm{O}_{3}$ & $\mathrm{TiO}_{2}$ & $\mathrm{P}_{2} \mathrm{O}_{5}$ & $\mathrm{Ki}$ & $\mathrm{Kr}$ & $\mathrm{Al}_{2} \mathrm{O}_{3} / \mathrm{Fe}_{2} \mathrm{O}_{3}$ \\
\hline & & …….... & $\ldots$ & $\ldots$ & $\ldots . \mathrm{g} \mathrm{kg}^{-}$ & & ...... & $\cdots$ & ......... \\
\hline 1 & LVwf petroplíntico & 24,6 & 295,9 & 305,4 & 83,35 & 2,67 & 0,14 & 0,09 & 1,52 \\
\hline 2 & LVwf típico & 49,6 & 258,1 & 303,6 & 59,50 & 1,31 & 0,33 & 0,19 & 1,33 \\
\hline 3 & LVwf típico & 67,0 & 308,9 & 315,6 & 68,60 & 1,16 & 0,37 & 0,22 & 1,54 \\
\hline 4 & LVdf típico & 98,9 & 284,7 & 305,5 & 64,75 & 1,24 & 0,59 & 0,35 & 1,46 \\
\hline
\end{tabular}

$\mathrm{Ki}=$ relação molar $\mathrm{SiO}_{2} / \mathrm{Al}_{2} \mathrm{O}_{3} ; \mathrm{Kr}=$ relação molar $\mathrm{SiO}_{2} / \mathrm{Al}_{2} \mathrm{O}_{3}+\mathrm{Fe}_{2} \mathrm{O}_{3}$

\section{Caracterização granulométrica}

Em relação à composição granulométrica, todos os quatros perfis de solos foram classificados como de textura muito argilosa, segundo Santos et al. (2013) (Tabela 10). Resultados semelhantes foram obtidos por Oliveira et al (2010) em Latossolos Vermelhos Acriférricos de Jataí, e por Curi e Franzmeier (1984) em Latossolos Distroférricos e Acriférricos na região de Itumbiara, GO, ambos derivados de basaltos.

Tabela 10. Análises granulométricas dos perfis dos solos 1, 2, 3 e 4 estudados na Usina Goiasa, Goiatuba, GO.

$\begin{array}{ccccccc} & \text { Prof } & \text { Areia } & \text { Silte } & \text { Argila } & \text { Relação } & \text { Classificação } \\ \text { Horizontes } & (\mathrm{cm}) & & & & \text { Silte/Argila } & \text { Textural }\end{array}$

$\mathrm{g} \mathrm{kg}^{-1}$

\begin{tabular}{|c|c|c|c|c|c|c|}
\hline \multicolumn{7}{|c|}{ Latossolo Vermelho Acriférrico petroplíntico - P1 } \\
\hline $\mathrm{A}$ & $0-20$ & 179 & 184 & 637 & 0,29 & Muito Argilosa \\
\hline $\mathrm{AB}$ & $20-65$ & 189 & 174 & 637 & 0,27 & Muito Argilosa \\
\hline Bw1 & $65-120$ & 177 & 163 & 660 & 0,25 & Muito Argilosa \\
\hline $\mathrm{F}$ & $120-220$ & 152 & 188 & 660 & 0,28 & Muito Argilosa \\
\hline Bwf2 & $220+$ & 183 & 169 & 648 & 0,26 & Muito Argilosa \\
\hline \multicolumn{7}{|c|}{ Latossolo Vermelho Acriférrico típico - P2 } \\
\hline A & $0-25$ & 111 & 246 & 643 & 0,38 & Muito Argilosa \\
\hline $\mathrm{AB}$ & $25-36$ & 133 & 196 & 671 & 0,29 & Muito Argilosa \\
\hline Bw1 & $36-63$ & 123 & 206 & 671 & 0,31 & Muito Argilosa \\
\hline Bw2 & $63-140$ & 120 & 191 & 689 & 0,28 & Muito Argilosa \\
\hline Bw3 & $140-250+$ & 115 & 196 & 689 & 0,28 & Muito Argilosa \\
\hline \multicolumn{7}{|c|}{ Latossolo Vermelho Acriférrico típico - P3 } \\
\hline A & $0-50$ & 128 & 220 & 652 & 0,34 & Muito Argilosa \\
\hline Bw1 & $50-78$ & 98 & 197 & 705 & 0,28 & Muito Argilosa \\
\hline Bw2 & $78-250+$ & 99 & 183 & 718 & 0,25 & Muito Argilosa \\
\hline \multicolumn{7}{|c|}{ Latossolo Vermelho Distroférrico típico - P4 } \\
\hline A & $0-25$ & 85 & 212 & 703 & 0,30 & Muito Argilosa \\
\hline Bw1 & $25-48$ & 71 & 189 & 740 & 0,26 & Muito Argilosa \\
\hline Bw2 & $48-150$ & 66 & 180 & 754 & 0,24 & Muito Argilosa \\
\hline Bw3 & $150-250+$ & 63 & 183 & 754 & 0,24 & Muito Argilosa \\
\hline
\end{tabular}




\section{Caracterização físico-hídrica - Densidade do solo e macro, meso e microporosidade}

No par de solos LVwf petroplíntico (P1) e LVwf (P2), a densidade do solo (Ds) foi superior no P1 nas profundidades de 0-15 cm e 150-210 cm em relação ao P2 (Figura 6). O maior valor de Ds no P1 a 0-15 cm, provavelmente, esteja relacionada ao intenso tráfego de máquinas em condição de solo mais úmido, em virtude da presença de horizonte concrecionário em subsuperfície, fator este que pode intensificar a compactação superficial do solo. Dias Junior e Estanislau (1999) avaliaram o grau de compactação em Latossolos de diferentes texturas, sob diferentes formas de manejos no município de Lavras, Estado de Minas Gerais, e foram associados os maiores valores de Ds em áreas cultivadas, ao solo úmido no momento do preparo, devido ao maior teor de argila e sua maior adsorção com a água em solos férricos (Silva et al. 1986). Em subsuperfície 150-210 cm, a média da Ds do P1 foi superior ao P2, provavelmente pela presença do horizonte plíntico em subsuperfície.
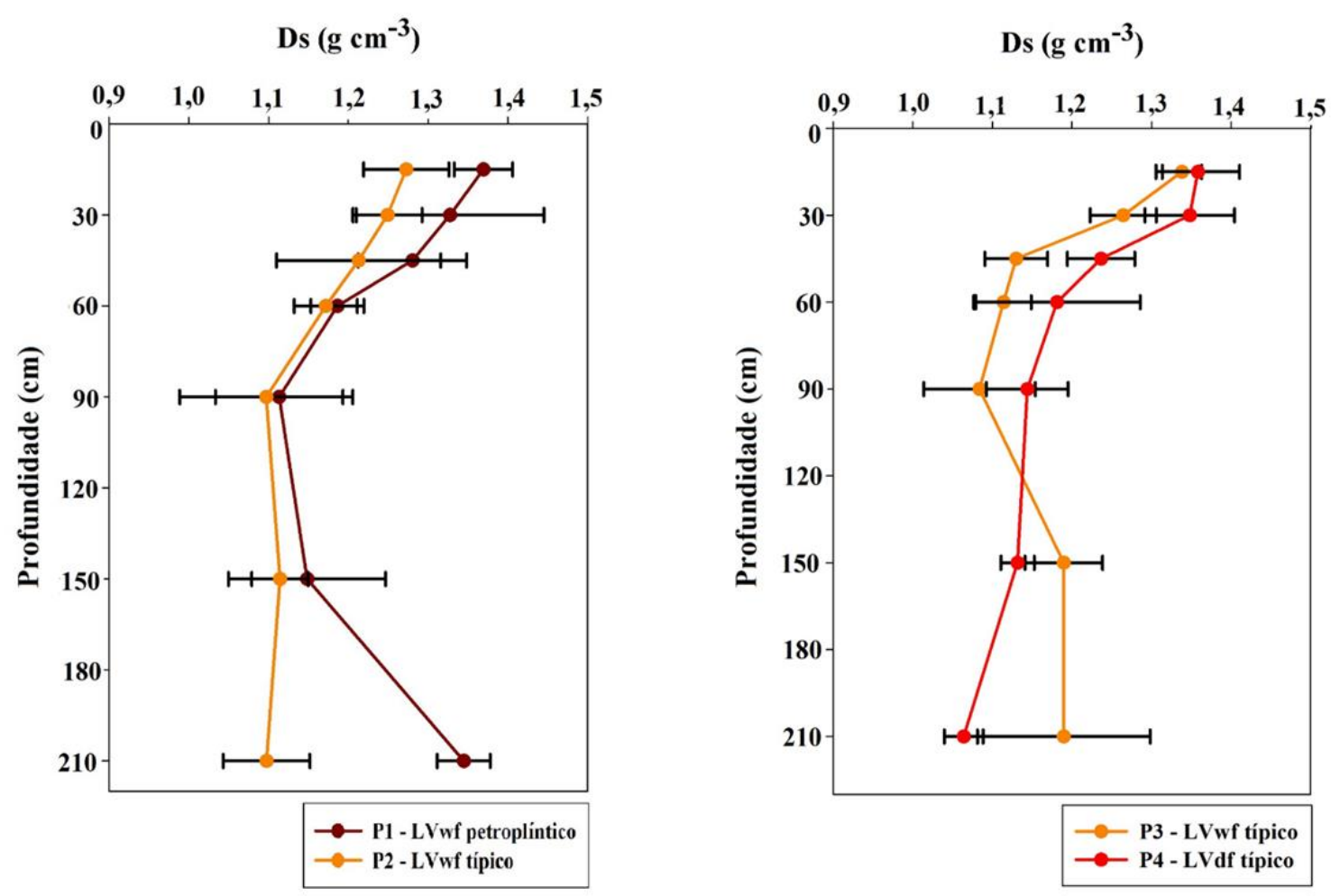

Figura 6. Densidade do solo (Ds) dos perfis de solos estudados: P1 e P2 (A); e P3 e P4 (B) na Usina Goiasa, Goiatuba, GO - barras correspondem ao erro pelo teste t a 5\% de probabilidade.

De acordo com Santos et al. (2013) no horizonte plíntico a presença de poros é menor, em função da maior massa de solo nesse horizonte em relação ao volume ocupado. Entretanto, Soares et al. (2005) e Souza et al. (2006) concluíram que o aumento da Ds em superfície e subsuperfície dos Latossolos Vermelhos, cultivados com cana-de-açúcar, foi devido ao intenso tráfego de máquinas durante a execução dos tratos culturais, reduzindo o 
desenvolvimento das raízes da cultura em profundidade e, provavelmente, afetou a produtividade da cana-de-açúcar. No P2, com ausência de horizonte concrecionário, a Ds do solo foi menor na mesma profundidade $(150-210 \mathrm{~cm})$. Provavelmente o intenso preparo de solo em áreas de cana-de-açúcar não tenha interferido na Ds em maiores profundidades e a diferença na Ds entre os perfis 1 e 2 seja associado a presença do horizonte plíntico abaixo do horizonte concrecionário (Tabela 6).

No par de solos P3 e P4 a diferença na Ds foi apenas na profundidade de $30-45 \mathrm{~cm}$ com valor superior para o P4. Este resultado, indica baixa variabilidade da Ds ao longo dos perfis do solo P3 e P4.

Em todos os Latossolos estudados (P1, P2, P3 e P4) a densidade do solo foi superior a $1,0 \mathrm{~g} \mathrm{~cm}^{-3}$, que de acordo com Goedert (2005), indica compactação dos solos e diminuição da qualidade agrícola dos solos tropicais.

A variável física Ds na profundidade de $0-30 \mathrm{~cm}$ nos dois pares de solos estudados variou de 1,25 a $1,37 \mathrm{~g} \mathrm{~cm}^{-3}$. De acordo com Klein e Libardi (2000) o limite de Ds de 1,11 g $\mathrm{cm}^{-3}$ foi considerado pelos autores como o de maior armazenamento de água para as plantas em Latossolos Vermelhos Ácriférricos de textura argilosa do município de Guaíra, Estado de São Paulo.

Os valores do volume total de poros (VTP) foi inversamente proporcional à Ds nos solos avaliados. Os menores valores médios do volume total de poros (VTP) na profundidade de $0-15 \mathrm{~cm}$ foram proporcionados pelo intenso tráfego em todos os Latossolos estudados, em solos de textura muito argilosa, conforme expressos na Figura 7.

Cury et al. (2014) observaram o mesmo comportamento reconhecidamente proporcional entre a densidade do solo e o volume total de poros em cana-de-açúcar cultivada em Latossolo Vermelho Eutroférrico de textura muito argilosa, onde o revolvimento do solo no plantio convencional causou a diminuição da Ds e o aumento do volume total de poros.

Entretanto, quando os solos são mecanizados, ou seja, trafegados de forma intensa, sua estrutura pode ser alterada, formando camadas compactadas decorrentes da redução da porosidade do solo (Araújo et al. 2007). De acordo com Goedert (2005), valores de VTP superiores a $0,60 \mathrm{~cm}^{3} \mathrm{~cm}^{-3}$ são indicativos de qualidade agrícola de solos de textura argilosa em clima tropical. Porém, o VTP nos quatro Latossolos estudados (P1, P2 e P4) foram inferiores a $0,60 \mathrm{~cm}^{3} \mathrm{~cm}^{-3}$ nas profundidades de $0-45 \mathrm{~cm}$, exceto no $\mathrm{P} 3$, com o valor do VTP de $0,62 \mathrm{~cm}^{3} \mathrm{~cm}^{-3}$ (Figura 7). 

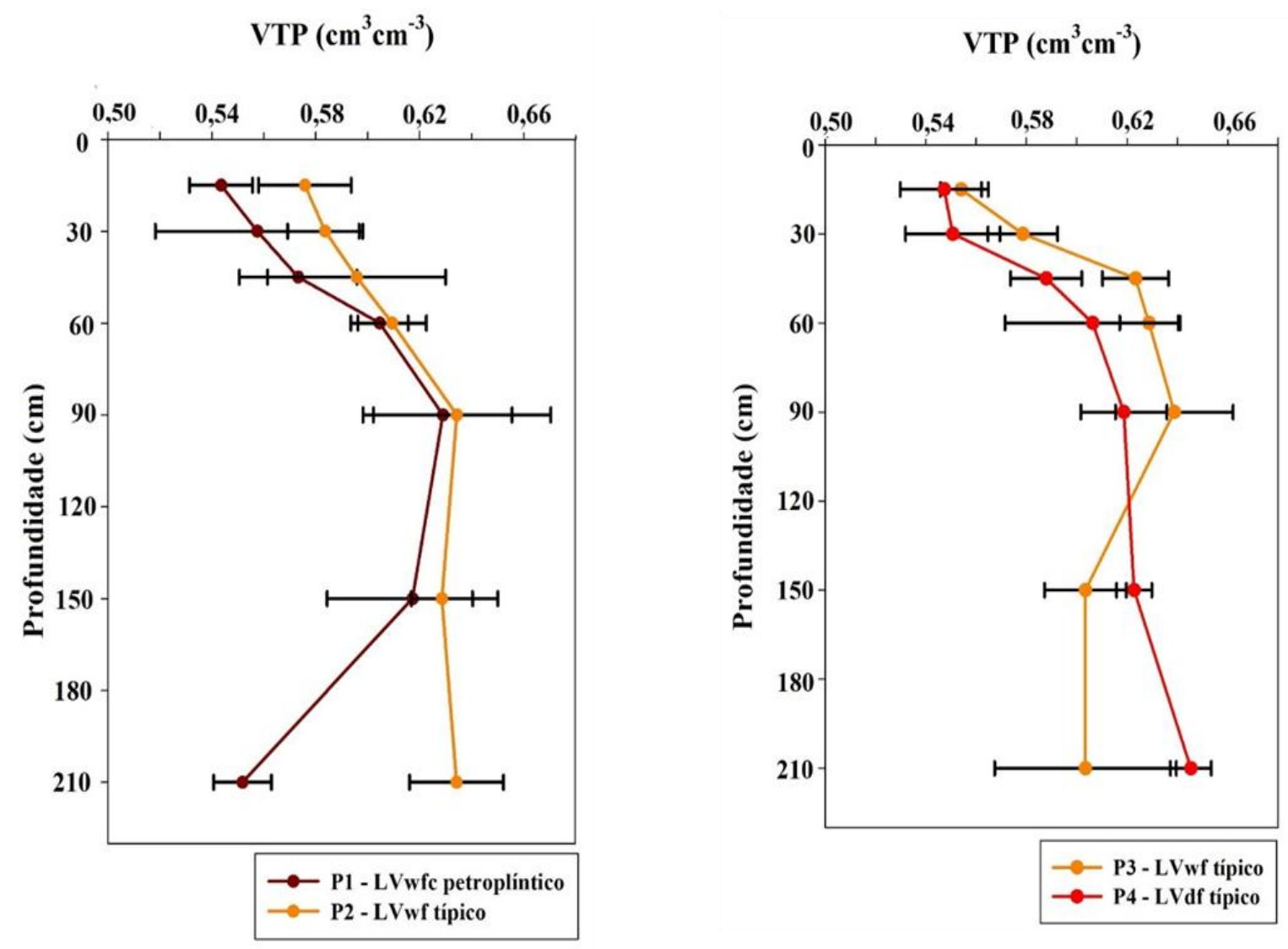

Figura 7. Volume total de poros (VTP) dos perfis de solos estudados P1 e P2 (A) e P3 e P4 (B) na Usina Goiasa, Goiatuba, GO - barras correspondem ao erro pelo teste t a $5 \%$ de probabilidade.

Lima et al. (2007) concluíram que a maior porosidade em Latossolos Vermelhos Distróficos típicos de textura franco-arenosa correlaciona-se de forma positiva com a produtividade da cultura do milho. No entanto, valores baixos de VTP de acordo com a textura do solo podem indicar a compactação do solos, interferindo na produtividade da cultura da cana-de-açúcar (Verma, 1995; Albuquerque e Reinert, 2001).

Paulino et al. (2004) estudaram o efeito da escarificação em Latossolos Vermelhos Distroférricos do município de Astorga, Estado do Paraná, em áreas cultivadas com cana-deaçúcar, e relataram que apesar do seu efeito no volume de poros, não houve diferença na produtividade da cultura no quarto corte, colhida no mês de julho.

Ao classificar o tamanho do diâmetro dos poros houve diferença no volume de macroporos (> 100 $\mathrm{m}$ ) nas profundidades de 0-15; 30-45 e 150 e $210 \mathrm{~cm}$ entre os solos P1 e P2, entretanto, nos solos P3 e P4 não foram observados contrastes nos valores de macroporosidade conforme expressos na Figura 8. 

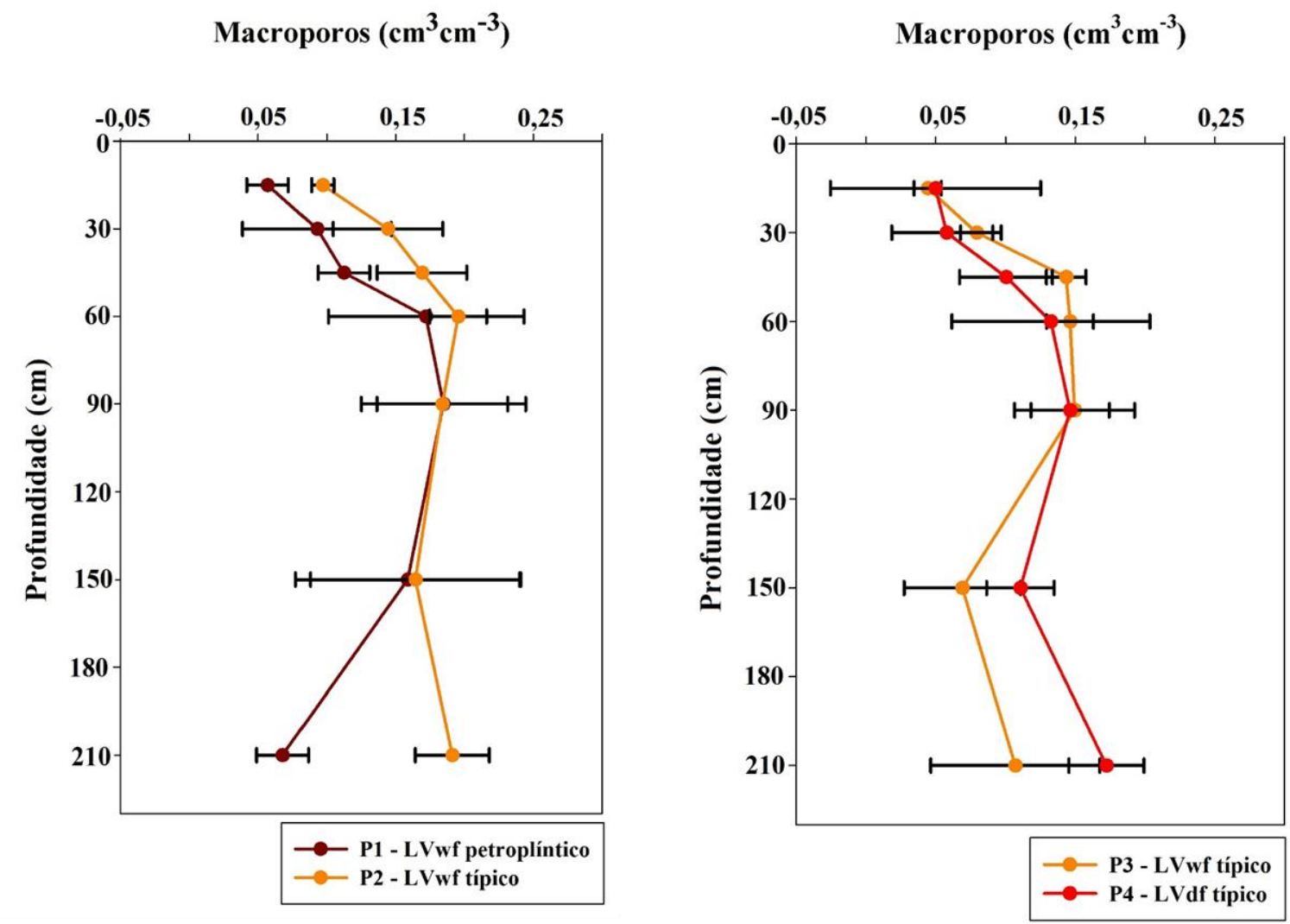

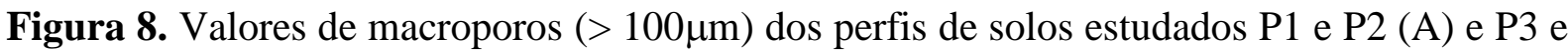
P4 (B) na Usina Goiasa, Goiatuba, GO - barras correspondem ao erro pelo teste t a 5\% de probabilidade.

Entretanto, ao considerar o limite crítico de troca gasosa no solo de $0,10 \mathrm{~cm}^{3} \mathrm{~cm}^{-3}$ proposto por Vomocil e Flocker (1966) os P1, P3 e P4 apresentaram valores inferiores a 0,10 $\mathrm{cm}^{3} \mathrm{~cm}^{-3}$ até a profundidade de $0-30 \mathrm{~cm}$, fator este que pode ter influenciado na movimentação do ar no perfil desses solos e nos processos de respiração pelo sistema radicular da cultura da cana-de-açúcar.

Soares et al. (2005) avaliaram a macroporosidade em Latossolos Vermelhos formados por rochas basálticas em lavouras de cana-de-açúcar no município de Bariri, Estado de São Paulo e concluíram que o tráfego excessivo de máquinas afetou o volume de macroporos em superfície e subsuperfície, apesar dos autores não avaliarem o efeito da proporção de macroporos na produtividade da cultura, foi relatado o menor aprofundamento do sistema radicular. Camilotti et al. (2005) observaram que o cultivo dos cortes posteriores (soqueiras) da cana-de-açúcar favoreceu o aumento dos macroporos dos solos em função do preparo destes e que não influenciou na produtividade da cultura cultivada em Latossolos Vermelhos Distróficos da região de Guariba, Estado de São Paulo. Por outro lado, Dexter (2004) demonstrou que o preparo excessivo do solo reduz a quantidade de macroporos e modifica a distribuição dos poros no solo. 
Em todos os solos (P1, P2, P3 e P4) o volume de mesoporos não se diferenciaram até $90 \mathrm{~cm}$ (Figura 9). Este resultado pode estar relacionado ao trânsito de máquinas uniforme nas lavouras de cana-de-açúcar sob sistema convencional. Os mesoporos $(100-30 \mu \mathrm{m})$ foram predominantes no P2 de 90-150 cm (Figura 9) comparado ao solo P1. Segundo Koorevaar et al. (1983) os mesoporos têm a função de conduzir a água do solo durante o processo de sua redistribuição no perfil do solo. O perfil de solo P2 têm menos microporos que retém água no solo quando comparado ao solo P1, facilitando o movimento de água no perfil do solo P2. No par P3 e P4 não foi observada diferenças no volume de mesoporos em todas as profundidades estudadas, possivelmente pela semelhança morfológica entre os solos P3 e P4.

Torres et al. (2014) ao avaliar o tamanho de poros do Latossolo Amarelo Distroférrico sob pastagem e mata nativa em Paragominas, estado do Pará, atribuiu a presença de mesoporos a $0-5 \mathrm{~cm}$ devido a movimentação dos animais na pastagem quando comparado a área mata nativa com predomínio de macroporos na mesma profundidade de avaliação, sendo o manejo do solo a causa da modificação do tamanho dos poros.
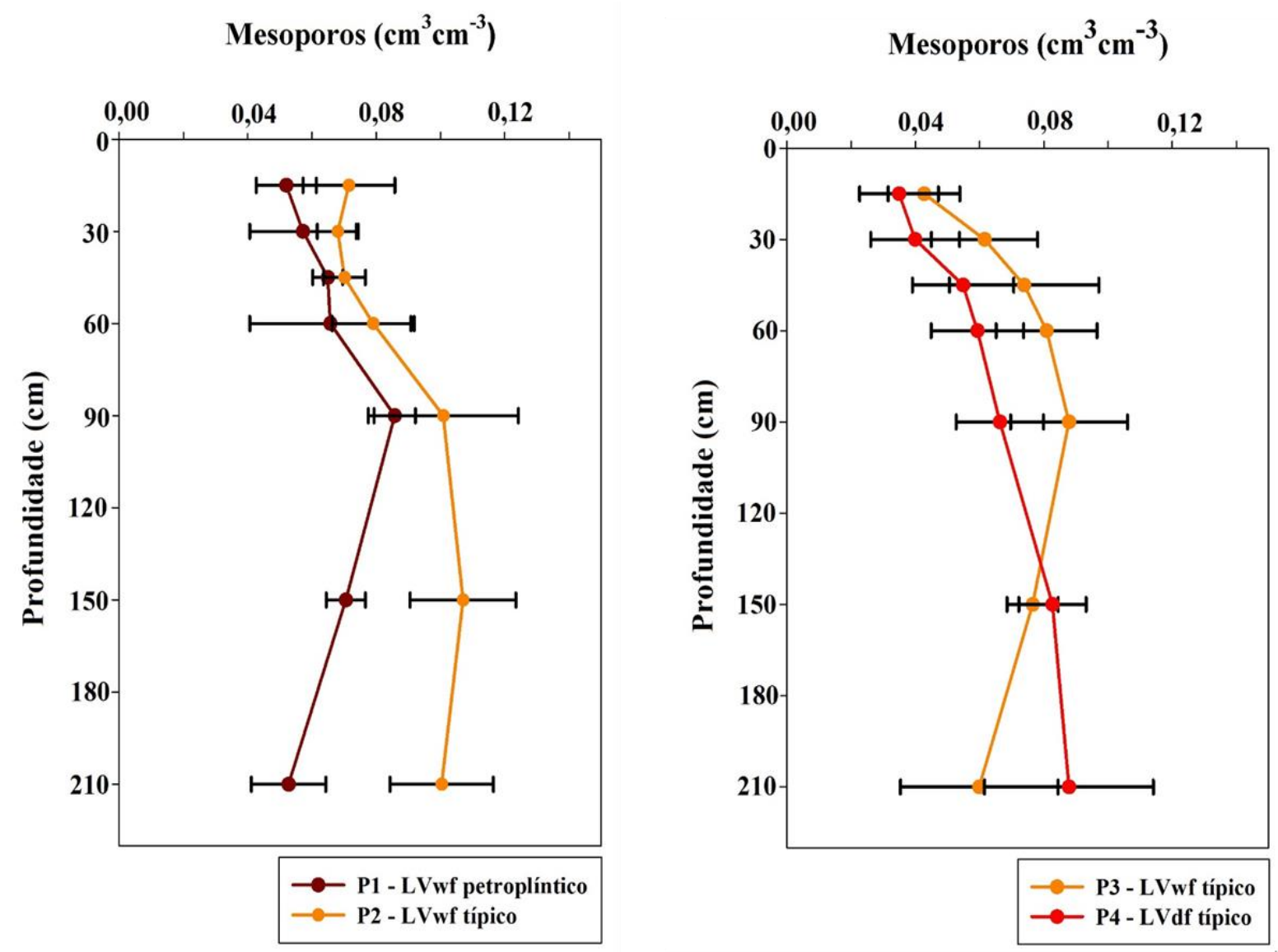

Figura 9. Valores de mesoporos $(\leq 100 \mathrm{a} \geq 30 \mu \mathrm{m})$ dos perfis de solos estudados P1 e P2 (A) e P3 e P4 (B) na Usina Goiasa, Goiatuba, GO - barras correspondem ao erro pelo teste t a 5\% de probabilidade. 
A comparação do atributo físico microporosidade entre os solos P1 e P2 indicou o aumento no volume de microporos a $150-210 \mathrm{~cm}$ no P1 (Figura 10), provavelmente este resultado esteja relacionado com a presença de plintita abaixo do horizonte concrecionário (Tabela 6). Cabe salientar que o limite de $30 \mu \mathrm{m}$ corresponde a água retida na tensão de 10 KPa, que esta próximo da capacidade de campo. Segundo Kiehl (1979) os microporos, ou poros capilares de acordo com Grohmmann (1960) têm a função de reter água nos solos.
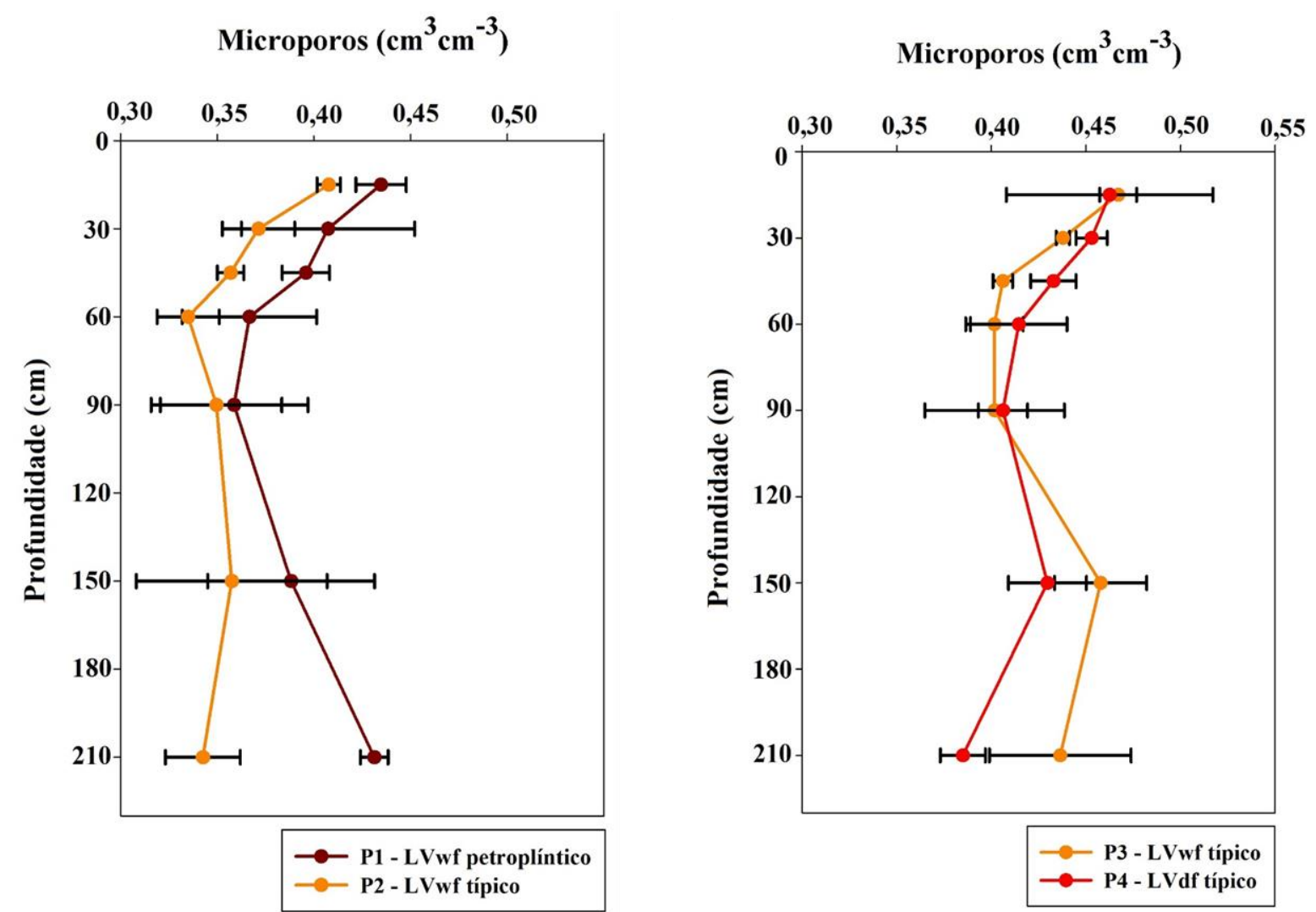

Figura 10. Valores de microporos $(<30 \mu \mathrm{m})$ dos perfis de solos estudados P1 e P2 (A) e P3 e P4 (B) na Usina Goiasa, Goiatuba, GO - barras correspondem ao erro pelo teste t a 5\% de probabilidade.

Grohmann (1960) demonstrou que o aumento de microporos em profundidade ocorreu devido ao expressivo grandiente textural no perfil da classe de solo Arenito Bauru (Argissolo) em Pindorama, SP. De acordo com mesmo autor em solos de textura argilosa os microporos são menos predominantes em profundidade em áreas não cultivadas e de mata nativa. Mediante este propósito a Tabela 11 apresenta a quantidade de microporos $(<30 \mu \mathrm{m})$ e macro e mesoporos (> $30 \mu \mathrm{m}$ ) nos perfis dos dois pares de solos estudados. Kiehl (1979) indica que para condições ideais para a produção agrícola o solo deve apresentar uma relação de 0,34 em macroporos $(>60 \mu \mathrm{m})$ e 0,66 em microporos $(<60 \mu \mathrm{m})$. Apesar dos resultados da Tabela 11 
não utilizarem os mesmos limites de tamanho de poros proposto por Kiehl (1979) nota-se contraste na distribuição de microporos entre os perfis dos pares de solos estudados.

Tabela 11. Volume de poros > $30 \mu \mathrm{m}$ (macro e mesoporos) e menores que $30 \mu \mathrm{m}$ (microporos) dos solos estudados na Usina Goiasa, Goiatuba, GO

\begin{tabular}{|c|c|c|c|c|c|c|c|c|}
\hline \multirow{3}{*}{$\begin{array}{c}\text { Prof. }^{2} \\
(\mathrm{~cm})\end{array}$} & \multicolumn{2}{|c|}{$\mathrm{P} 1$} & \multicolumn{2}{|c|}{$\mathrm{P} 2$} & \multicolumn{2}{|c|}{ P3 } & \multicolumn{2}{|c|}{$\mathrm{P} 4$} \\
\hline & . & $\cdots$ & .... & ..Diâmet & dos poros & 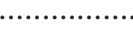 & . - . - . & … \\
\hline & $>30 \mu \mathrm{m}$ & $<30 \mu \mathrm{m}$ & $>30 \mu \mathrm{m}$ & $<30 \mu \mathrm{m}$ & $>30 \mu \mathrm{m}$ & $<30 \mu \mathrm{m}$ & $>30 \mu \mathrm{m}$ & $<30 \mu \mathrm{m}$ \\
\hline & . & $\ldots$ & . & ........cn & $\mathrm{cm}^{-3}$ & & & \\
\hline $0-15$ & 0,20 & 0,80 & 0,29 & 0,71 & 0,15 & 0,85 & 0,16 & 0,84 \\
\hline $15-30$ & 0,27 & 0,73 & 0,36 & 0,64 & 0,24 & 0,76 & 0,18 & 0,82 \\
\hline $30-45$ & 0,30 & 0,70 & 0,40 & 0,60 & 0,34 & 0,66 & 0,27 & 0,73 \\
\hline $45-60$ & 0,38 & 0,62 & 0,46 & 0,54 & 0,37 & 0,63 & 0,33 & 0,67 \\
\hline $60-90$ & 0,43 & 0,57 & 0,44 & 0,56 & 0,38 & 0,62 & 0,34 & 0,66 \\
\hline $90-150$ & 0,37 & 0,63 & 0,43 & 0,57 & 0,23 & 0,77 & 0,31 & 0,69 \\
\hline $150-210$ & 0,22 & 0,78 & 0,46 & 0,54 & 0,27 & 0,73 & 0,42 & 0,58 \\
\hline
\end{tabular}

No P1 a relação é superior a 0,66 de microporos a 0-45 cm; no P2 0-15 cm; P3 0-30 cm e no P4 0-60 cm de profundidade. Esse resultado indica forte interação com a Ds sendo possivelmente o efeito do excessivo tráfego de máquinas em condições de solo úmido, que nesses solos muito argilosos tornam proporcional a redução de macroporos e o predomínio de microporos na superfície dos quatro solos.

Em subsuperfície no solo P1 a proporção de microporos é maior a 150-210 cm e no P3 a 90-150 cm (Figura 10). Santos et al. (2013) relatam que em horizontes plínticos a presença de poros é menor devido a maior massa de solos em um determinado volume ocupado pela plintita. Entretanto, a descrição da morfologia no solo P3 (Tabela 6) não indicou a presença de plintita no perfil do solo, o que indica que a presença de microporos em profundidade possa estar associada a outros atributos dos solos.

Em todos os solos (P1, P2, P3 e P4) o volume de microporos foi maior na camada de 0-15 cm (Tabela 11). Nos solos P2 e P4 a 90-210 cm o valor médio do volume de microporos diminuiu, podendo estes valores influenciar na retenção de água pelos solos em subsuperfície.

Cury et al. (2014) avaliaram o efeito do sistema de cultivo convencional e plantio direto na biomassa do sistema radicular da cana-de-açúcar, cultivada em Latossolo Vermelho Eutroférrico, de textura muito argilosa, do município de Ribeirão Preto, SP, os autores verificaram maior volume de microporos a $5-20 \mathrm{~cm}$ de profundidade, no sistema de plantio convencional, sendo o trânsito excessivo de máquinas na mesma posição nas entrelinhas da 
cultura a causa dos maiores valores de microporos neste sistema de cultivo. Em subsupefície (40-60 cm), os autores não constataram diferença no volume de microporos nos dois sistemas de cultivo (convencional e direto) quando considerado os resultados do atributo físico obtidos na linha de plantio, possivelmente pelo efeito da sulcação na implantação da cultura, rompendo possíveis camadas compactadas dos solos.

\section{III.3.2. Disponibilidade de água no solos estudados}

Os valores de água disponível entre todos os perfis de solos variaram de 0,06 a 0,13 $\mathrm{cm}^{3} \mathrm{~cm}^{-3}$. Valores semelhantes de água disponível no horizonte B de Latossolos do Cerrado foram observados por Reatto et al. (2007). A presença do horizonte concrecionário não influenciou o teor de água disponível (tensões entre 10 e $1500 \mathrm{kPa}$ ) entre os solos P1 - LVwf petroplíntico e P2 - LVwf típico. A mesma tendência foi observada entre os solos de características químicas distintas representados por P3 - LVwf típico e P4 - LVdf típico, respectivamente (Tabela 12).

Tabela 12. Água disponível em milímetro (média \pm erro) nos quatro solos estudados da Usina Goiasa, Goiatuba, GO.

\begin{tabular}{|c|c|c|c|c|}
\hline Prof. $^{1}$ & $\begin{array}{l}\text { Perfil 1-LVwd } \\
\text { petroplíntico }\end{array}$ & Perfil 2 - LVwf & Perfil 3 - LVwf & Perfil 4 LVdf \\
\hline$(\mathrm{cm})$ & & ........ (1 & & \\
\hline $0-15$ & $18,0 \pm 1,5$ & $15,0 \pm 1,5$ & $18,0 \pm 1,5$ & $15,0 \pm 4,5$ \\
\hline $15-30$ & $13,5 \pm 3,0$ & $12,0 \pm 3,0$ & $15,0 \pm 1,5$ & $15,0 \pm 1,5$ \\
\hline $30-45$ & $13,5 \pm 4,5$ & $12,0 \pm 1,5$ & $15,0 \pm 1,5$ & $13,5 \pm 3,0$ \\
\hline $45-60$ & $12,0 \pm 1,5$ & $10,5 \pm 3,0$ & $15,0 \pm 1,5$ & $15,0 \pm 3,0$ \\
\hline $60-90$ & $27,0 \pm 9,0$ & $30,0 \pm 3,0$ & $30,0 \pm 6,0$ & $27,0 \pm 6,0$ \\
\hline $90-150$ & $60,0 \pm 12,0$ & $60,0 \pm 18,0$ & $78,0 \pm 12,0$ & $66,0 \pm 24,0$ \\
\hline $150-210$ & $60,0 \pm 6,0$ & $66,0 \pm 12,0$ & $66,0 \pm 12,0$ & $66,0 \pm 12,0$ \\
\hline Total $(\mathrm{mm})$ & 204,0 & 205,5 & 237,0 & 217,5 \\
\hline
\end{tabular}

Determinado pelo teste $\mathrm{t}$ a $5 \%$ de probabilidade

(1) Profundidade de amostragem

Campos et al. (2010), também não obtiveram diferença no teor de água disponível entre os Latossolos Vermelhos Ácricos e Latossolos Vermelho-Amarelos Ácricos petroplínticos do Distrito Federal. Entretanto, Beutler et al. (2002) observaram diferenças na capacidade de água disponível entre o Latossolo Vermelho distrófico de textura média/argilosa e o Latossolo Vermelho eutroférrico, típico, de textura argilosa/argilosa sob sistema de cultivo de algodão, cana-de-açúcar e mata nativa no município de Jaboticabal, 
Estado de São Paulo. O efeito da textura nos atributos físico-hídricos é relatado por Costa et al. (2013), que observou em diversos solos de textura arenosa, siltosa, argilosa e muito argilosa, que a retenção hídrica foi superior em solos argilosos e siltosos, devido a maior força de retenção da água nesses solos. Já Demattê e Demattê (2009) e Alleoni e Camargo (1994), consideram a água disponível baixa em Latossolos de textura argilosa, devido à forte microagregação da fração argila, o que torna limitante o fornecimento de água para as plantas.

Reatto et al. (2007) não observaram diferenças nos valores de água disponível entre Latossolos ácricos e distróficos da região do Cerrado Brasileiro, porém mencionaram que o maior teor de argila afetou de maneira positiva a retenção de água disponível nos solos.

De acordo com van Wambeke (1974) água disponível para plantas cultivadas em Latosolos é quando ocorre uma proporção de $1 \mathrm{~mm}$ de lâmina de água disponível por $10 \mathrm{~mm}$ de profundidade dos solos. Klein e Libardi (2000) relacionam a Ds como fator determinante para o maior armazenamento de água em Latossolo Vermelho Ácriférrico do município de Guaíra, estado de São Paulo. Segundo os autores, a Ds entre 1,0 e 1,1 $\mathrm{g} \mathrm{cm}^{-3}$ condiciona uma faixa de umidade menos limitante para o desenvolvimento das culturas, em torno de $0,12 \mathrm{~m}^{3}$ $\mathrm{m}^{-3}$. Entretanto, os resultados de Ds variaram entre 1,25 a $1,37 \mathrm{~g} \mathrm{~cm}^{-3}$ a $0-30 \mathrm{~cm}$, condicionando uma faixa de umidade mais limitante para o desenvolvimento das culturas.

\section{Avaliação do potencial hídrico foliar na variedade RB867515}

O potencial hídrico $\left(\Psi_{\mathrm{w}}\right)$ foliar expressa o status de água na planta integrando o efeito do sistema radicular e da demanda evapotranspirativa. Na comparação entre os pares de solos P1 e P2 o fator de maior destaque no potencial de água nas folhas foi à presença do horizonte concrecionário em subsuperfície no P1 no ano de 2014 (Tabela 13), e a presença de microporos no horizonte Bw com caráter plíntico abaixo do horizonte concrecionário (Tabela 6).

Tabela 13. Potencial hídrico foliar no mês de agosto nos diferentes pares de solos (P1 - LVwf petroplíntico e P2-LVwf; P3 - LVwf e P4 - LVdf) estudados na Usina Goiasa, Goiatuba, GO.

Período de Avaliação

\begin{tabular}{|c|c|c|}
\hline Classes de Solos & 2014 & 2015 \\
\hline & \multicolumn{2}{|c|}{ 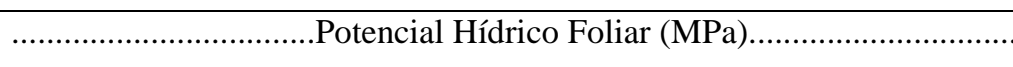 } \\
\hline P1 -LVwf petroplíntico & $-0,1 b$ & $-1,1 \mathrm{a}$ \\
\hline P2 - LVwf típico & $-0,6 \mathrm{a}$ & $-1,5 \mathrm{a}$ \\
\hline P3 - LVwf típico & $-0,4 a$ & $-1,4 \mathrm{a}$ \\
\hline P4 - LVdf típico & $-0,4 \mathrm{a}$ & $-1,5 \mathrm{a}$ \\
\hline
\end{tabular}

Médias seguidas com a mesma letra nas colunas não diferem do teste t a 5\% de probabilidade. 
A precipitação pluviométrica que ocorreu no mês de julho do ano de 2014 (Tabela 14) permitiu que a cana-de-açúcar obtivesse os valores mais elevados de potencial hídrico foliar no solo P1 (-0,1 MPa) em relação ao P2 (-0,6 MPa).

Tabela 14. Médias mensais de precipitação pluviométrica nos anos de 2014 e 2015 na Usina Goiasa, GO.

Precipitação Pluviométrica durante o ano de 2014

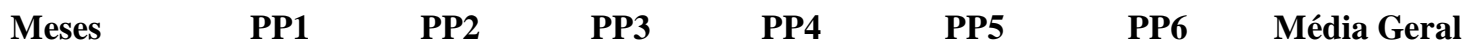

\begin{tabular}{|c|c|c|c|c|c|c|c|}
\hline Janeiro & 86 & 71 & 71 & 53 & 66 & 46 & 66 \\
\hline Fevereiro & 166 & 125 & 94 & 176 & 174 & 119 & 142 \\
\hline Março & 352 & 335 & 294 & 346 & 310 & 408 & 341 \\
\hline Abril & 73 & 57 & 97 & 65 & 79 & 98 & 78 \\
\hline Maio & - & 10 & - & - & - & - & 2 \\
\hline Junho & - & - & - & - & - & - & - \\
\hline Julho & 75 & 75 & 72 & 78 & 86 & 84 & 78 \\
\hline Agosto & - & - & - & - & - & - & - \\
\hline Setembro & 34 & 40 & 35 & 39 & 23 & 30 & 33 \\
\hline Outubro & 42 & 109 & 117 & 145 & 72 & 30 & 86 \\
\hline Novembro & 256 & 226 & 328 & 391 & 311 & 299 & 302 \\
\hline Dezembro & 154 & 160 & 201 & 147 & 168 & 107 & 156 \\
\hline Total & 1.238 & 1.208 & 1.309 & 1.440 & 1.289 & 1.221 & 1.284 \\
\hline
\end{tabular}

Precipitação Pluviométrica durante o ano de 2015

\begin{tabular}{|c|c|c|c|c|c|c|c|}
\hline & ...... & $\ldots$ & 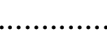 & ......mm. & …......... & ............. & \\
\hline Janeiro & 75 & 92 & 149 & 97 & 42 & 44 & 83 \\
\hline Fevereiro & 230 & 282 & 224 & 232 & 242 & 236 & 241 \\
\hline Março & 222 & 285 & 204 & 279 & 322 & 268 & 263 \\
\hline Abril & 127 & 146 & 87 & 209 & 106 & 110 & 131 \\
\hline Maio & 39 & 42 & 44 & 44 & 25 & 27 & 37 \\
\hline Junho & 22 & 57 & 8 & 15 & 5 & 9 & 19 \\
\hline Julho & 11 & 10 & 9 & 10 & 8 & 22 & 12 \\
\hline Agosto & 5 & 9 & 7 & - & 5 & - & 4 \\
\hline Setembro & 42 & 58 & 48 & 40 & 47 & 33 & 45 \\
\hline Outubro & 86 & 66 & 115 & 120 & 152 & 70 & 101 \\
\hline Novembro & 250 & 148 & 248 & 234 & 196 & 152 & 205 \\
\hline Dezembro & 42 & 17 & 95 & 77 & 40 & 77 & 58 \\
\hline Total & 1.151 & 1.213 & 1.238 & 1.357 & 1.190 & 1.048 & 1.199 \\
\hline
\end{tabular}


Machado et al. (2009) avaliaram o potencial hídrico foliar de variedades de cana-deaçúcar em sistema com umidade controlada, com volumes de água disponível próximo à capacidade de campo, cujos valores de $\Psi_{\mathrm{w}}$ foliar variaram entre -0,18 a -0,27 MPa para o estádio fenológico de maior acúmulo de sacarose (período equivalente ao observado no campo).

No ano de 2015, não houve no meio do ano a alta precipitação pluviométrica registrada do ano anterior, e as médias de potencial hídrico foliar foram menores comparadas às de 2014, em ambos os pares de solos, que não se diferiram entre si.

Entretanto, mesmo não havendo diferenças estatísticas entre os dois pares de solos em 2015 o $\Psi \mathrm{w}$ foliar apresentou tendência superior no solo P1 - LVdf petroplíntico, demonstrando que o horizonte concrecionário deve ter atenuado o estresse hídrico da cultura no período de avaliação. Portanto, a cultura acumulou mais água do que solos sem a presença do horizonte concrecionário.

Por outro lado, Vieira et al. (2014), ao estudar o efeito do estresse hídrico na variedade de cana-de-açúcar RB867515, cultivada em solo arenoso do município de Jaíba, Estado de Minas Gerais, verificaram que a cultura quando submetida ao estresse hídrico, com altos valores de $\Psi_{\mathrm{w}}$ foliar (-0,1 $\left.\mathrm{MPa}\right)$ foi menos produtiva.

Pincelli (2010) avaliou o potencial hídrico foliar em diferentes variedades de cana-deaçúcar no município de Jaú, estado de São Paulo, para identificação do ponto de estresse hídrico. Os valores de potencial hídrico foliar foram avaliados em duas épocas (112 e 140 dias após o plantio), sendo que as leituras da primeira e segunda épocas variaram de -1,67 a -3,02 MPa e -2,11 a -3,09 MPa, respectivamente, sendo a variação dos valores de potencial hídrico foliar atribuída aos genótipos de cana-de-açúcar.

Ressalta-se que a capacidade genética das diferentes variedades de cana-de-açúcar deve ser considerada em estudos que avaliam o $\Psi_{\mathrm{w}}$ foliar, onde em determinadas condições climáticas, alguns genótipos manifestam específicos mecanismos fisiológicos no aproveitamento de água do solo (Machado et al., 2009; Silva et al., 2014; Rodolfo Júnior, 2015).

\section{III.3.3. Produtividade da variedade de cana-de-açúcar nos solos estudados}

A avaliação do rendimento da variedade RB867515 em função das épocas de colheita (maio, agosto e outubro) indicaram diferenças na produtividade entre os dois pares de solos estudados nos anos de 2014 e 2015. Entre os solos 1 - LVwf petroplíntico e 2 - LVwf típico os contrastes na produtividade foram verificados nas avaliações da produtividade dos meses 
de maio e agosto no ano de 2014. No ano de 2015 as diferenças nas pesagens da cultura nos locais foram verificadas nos meses de maio e outubro (Tabela 15). Ressalta-se que em plena estação seca, no mês de julho de 2014 ocorreu precipitação pluviométrica, com valores médios acumulados de $78 \mathrm{~mm}$ (Tabela 14), caracterizando-se como um evento climático atípico na região, onde, geralmente, as médias acumuladas de precipitação pluviométrico no mês de julho são da ordem de 7 a 16 mm (Climatempo, 2016). Silva et al. (2008) enfatizaram o efeito da precipitação pluviométrica acumulada de $91 \mathrm{~mm}$ entre as épocas de corte de inverno e primavera como o fator fundamental no aumento da produtividade da cana-deaçúcar em 9,21 $\mathrm{Mg} \mathrm{ha}^{-1}$ cultivada em Latossolo Vermelho Eutroférrico do município de Jaú, SP.

Tabela 15. Produtividade da cana-de-açúcar obtida por pesagem da variedade RB867515, nas diferentes épocas de corte nos solos estudados da Usina Goiasa, GO.

\begin{tabular}{|c|c|c|c|}
\hline \multirow[b]{2}{*}{ Pares de classes de solos } & \multicolumn{3}{|c|}{.............Produtividade da cana-de-açúcar $\left(\mathrm{Mg} \mathrm{ha}^{-1}\right)$ em 2014.............. } \\
\hline & $1^{a}$ Época - Maio & $2^{\mathrm{a}}$ Época - Agosto & 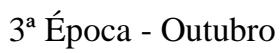 \\
\hline P1 - LVwf petroplíntico & $59,47 \mathrm{~b}$ & $97,82 \mathrm{a}$ & $63,97 \mathrm{a}$ \\
\hline P2 - LVwf típico & $73,93 a$ & $64,68 b$ & $53,77 \mathrm{a}$ \\
\hline P3 - LVwf típico & $70,77 \mathrm{a}$ & $67,63 \mathrm{a}$ & $57,70 \mathrm{~b}$ \\
\hline \multirow[t]{2}{*}{ P4 - LVdf típico } & $51,67 \mathrm{~b}$ & $64,17 \mathrm{a}$ & $66,73 a$ \\
\hline & \multicolumn{3}{|c|}{...Produtividade da cana-de-açúcar $\left(\mathrm{Mg} \mathrm{ha}^{-1}\right)$ em 2015.................. } \\
\hline Pares de classes de solos & 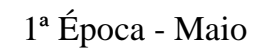 & $2^{\mathrm{a}}$ Época - Agosto & 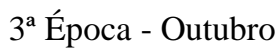 \\
\hline P1 - LVwf petroplíntico & $36,57 \mathrm{~b}$ & $62,73 a$ & $60,57 \mathrm{a}$ \\
\hline P2 - LVwf típico & $42,97 \mathrm{a}$ & $56,90 \mathrm{a}$ & $51,73 b$ \\
\hline P3 - LVwf típico & $32,60 \mathrm{~b}$ & $54,50 \mathrm{a}$ & $51,23 \mathrm{a}$ \\
\hline P4 - LVdf típico & $36,13 \mathrm{a}$ & $52,67 \mathrm{a}$ & $51,47 \mathrm{a}$ \\
\hline
\end{tabular}

Mesma letra dentro de cada coluna para cada por de solos não difere pelo teste t a 5\% de probabilidade.

Entre os solos 3 - LVwf típico e 4 - LVdf típico o maior contraste na produtividade foi constatado nas avaliações dos meses de maio e outubro de 2014. No ano seguinte, houve diferença na produtividade somente no mês de maio. Gava et al. (2011) estudaram o efeito da precipitação pluviométrica na produtividade da cana-de-açúcar em dois ciclos da cultura cultivada no Argissolo eutrófico no munícipio de Jaú. SP, e concluíram que a redução no volume de precipitação pluviométrica em $87 \mathrm{~mm}$ entre o primeiro e segundo cortes respectivamente, proporcionaram redução de $22,1 \mathrm{Mg}^{-1}$ na produtividade da cana-deaçúcar. 
Em relação ao ano de 2014 nos solos P1 e P2, a presença do horizonte concrecionário no P1, provavelmente, possibilitou encharcamento do solo P1 o que pode ter contribuído para a avaliação da produtividade no mês de maio de 2014 comparado ao solo P2. Na segunda avaliação de produtividade, no mês de agosto de 2014, a maior disponibilidade de água no solo com horizonte concrecionário em subsuperfície, pode ter proporcionado os maiores valores de produtividade da cultura. Na avaliação realizada no mês de agosto de 2014 a produtividade da cana-de-açúcar no $\mathrm{P} 1$ foi superior em $33,14 \mathrm{Mg} \mathrm{ha}^{-1}$ comparado ao $\mathrm{P} 2$, o qual não possui horizonte concrecionário em subsuperfície. A produtividade da variedade RB867515 no mês de outubro de 2014, apesar de não se diferir estatisticamente entre os solos P1 e P2, mostrou a mesma tendência, superior em 10,20 $\mathrm{Mg} \mathrm{ha}^{-1}$ em relação ao solo P2.

Em 2015, a média da precipitação pluviométrica em julho foi de 11,58 mm, normal para a região, porém, muito abaixo do ano anterior. Entre os solos 1 - LVwf petroplíntico e 2 - LVwf típico a produtividade da cana-de-açúcar foi superior no P2 no mês de maio de 2015, provavelmente pelo encharcamento no solo 1 - LVwf petroplíntico resultando em menor produtividade da cultura. Entretanto, no mês de outubro de 2015, o P1, apresentou produtividade $8,84 \mathrm{Mg} \mathrm{ha}^{-1}$ maior em relação ao $\mathrm{P} 2$, reforçando a importância do horizonte concrecionário na retenção de água no horizonte subsuperficial, mesmo em condições de baixa precipitação pluviométrica. Tal como nesse trabalho, Papa et al. (2011) relataram que a presença de horizonte concrecionário em Latossolos Vermelho-Amarelos de textura muito argilosa do Distrito Federal, devido ao acúmulo até a saturação de água ao longo do perfil destes solos na estação chuvosa diminuem o potencial agrícola destes solos nesta estação, no entanto, estes solos podem ter aptidão agrícola melhorada no período da seca, em culturas de enraizamento mais profundo, pois retém água em condições subsuperficiais. Já Mesquita et al. (2007) consideraram a presença de horizonte concrecionário em profundidade como um fator restritivo para o Araticum ocorrer naturalmente explicando sua ausência em Latossolos petroplínticos no estado de Goiás.

Assim, quando existem características morfológicas, tal como o horizonte concrecionário, que permitem a permanência do lençol freático próximo à zona radicular da cana-de-açúcar, o efeito de retenção hídrica pode beneficiar a produtividade desta cultura.

O comportamento produtivo da variedade de cana-de-açúcar RB867515 em Latossolos com caracteres químicos distintos foi verificado nos solos P3 - LVwf típico e P4 - LVdf típico. Em 2014, no mês de maio, a produtividade da cana-de-açúcar diferiu-se entre esses solos, sendo superior em $19,1 \mathrm{Mg} \mathrm{ha}^{-1}$ no $\mathrm{P} 3 \mathrm{em}$ relação à produtividade do $\mathrm{P} 4$, provavelmente, em função da localização do P3, no terço inferior da paisagem, enquanto que 
o P4 situa-se no terço médio. A localização desses solos na paisagem pode indicar disponibilidade hídrica variável em ambos os solos, principalmente no mês de maio de 2014, decorrente do término da estação chuvosa na região de estudo (Tabela 14).

No mês de outubro de 2014, a pesagem da cana-de-açúcar no P3 e P4 indicou valores superiores de produtividade para o P4 (LVdf), com valor de 9,03 $\mathrm{Mg} \mathrm{ha}^{-1}$ superior ao P3 (LVwf). Ressalta-se que o manejo químico da correção e adubação dos quatro solos avaliados foram os mesmos. Segundo Landell et al. (2003), nos Latossolos a longevidade e a produtividade da cana-de-açúcar a partir do terceiro corte está diretamente relacionada às características químicas de subsuperfície dos solos, ou seja, o caráter distrófico em profundidade pode ter permitido ambiente mais adequado ao desenvolvimento da variedade de cana-de-açúcar RB867515 no P4 em relação ao P3, que apresenta caráter ácrico.

$\mathrm{Na}$ mesma linha de pesquisa, Joaquim et al. (1997) observaram que entre os Latossolos com mesma composição granulométrica, os solos de caráter químico distrófico são mais produtivos que os solos ácricos, devido à baixa retenção de cátions em profundidade. Dias et al. (1999) destacaram a importância do caráter químico de subsuperfície para a produtividade da cana-de-açúcar em Argissolos, Latossolos e Neossolos Quartzarênicos do noroeste do estado de São Paulo. Ribeiro et al. (1984) enfatizam que a soma de bases do horizonte $\mathrm{Bw}$ foi o fator que mais influenciou a produtividade da cana-de-açúcar, sendo $27 \%$ de $71 \%$ da variabilidade do rendimento da cultura da cana-de-açúcar, devido ao melhor ambiente radicular nos Latossolos distróficos para o desenvolvimento da cultura da cana-deaçúcar.

Já em 2015, a variação de produtividade da cana-de-açúcar no mês de outubro, correspondente à quarta e última colheita do ano, não foi constatada nos solos P3 e P4. Foi observado variação na produtividades desses solos somente em maio, com maior produtividade da variedade RB867515 no P4. Apesar da variedade RB867515 ser adaptada a ambientes hídricos restritivos (Ridesa, 2010), a cana-de-açúcar no solo (P3) poderia estar mais debilitada na quarta safra agrícola.

No entanto, deve-se ressaltar que após a terceira avaliação de produtividade (outubro de 2014), a Usina Goiasa repassou a colheitadeira nas quatro áreas avaliadas, correspondendo às áreas de influência de P1, P2, P3 e P4, colhendo a cana-de-açúcar em toda a área demarcada; tal fato pode ter ocasionado redução na brotação de novos perfilhos das soqueiras avaliadas na quarta colheita agrícola, no mês de outubro.

Desta forma, as condições determinantes para a variabilidade nas produtividades nos solos P3 e P4, podem não estar somente atribuídas ao caráter químico de subsuperfície dos 
solos. Foi verificada diferença nos teores de $\mathrm{Ca}$ e $\mathrm{Mg}$ do complexo sortivo do horizonte $\mathrm{Bw}$ dos solos P3 - LVwf típico e P4 - LVdf típico, entretanto, a distinção do caráter distrófico e ácrico desses solos em função dos valores de $\mathrm{RC}, \Delta \mathrm{pH}, \mathrm{pH}$ em $\mathrm{KCl}$, conforme SiBCS (Embrapa, 2013) é tênue. (Tabela 7). Geralmente os Latossolos distróficos típicos tem alta saturação de alumínio (Al) e altos teores de bases trocáveis na subsuperfície, ao cotrário dos Latossolos ácricos e dos Latossolos distróficos estudados na usina Goiasa.

O atributo físico densidade do solo Ds nos dois pares de solos a 0-15 cm variou entre 1,37 no P1 e 1,27 $\mathrm{g} \mathrm{cm}^{-3}$ no P2 e 1,34 no P3 e no P4 1,36 $\mathrm{g} \mathrm{cm}^{-3}$ (Figura 6). Prado (1993) concluiu que valores de Ds em Latossolo Vermelho férrico, textura argilosa, sob mata nativa de 0,94 a $1,02 \mathrm{~g} \mathrm{~cm}^{3}$ e valores limítrofes de $1,1 \mathrm{~g} \mathrm{~cm}^{3}$ em solos sob vegetação de Cerrado são considerados valores de solos não compactados. Mediante esses resultados de Ds pode-se concluir que os quatros solos foram compactados, em decorrência da movimentação de máquinas durante a realização dos tratos culturais da cana-de-açúcar. De acordo com Souza et al. (2005) a presença de palhada incorporada ao solo melhorou os atributos físicos dos solos dentre eles a redução da Ds e elevou a produtividade da cana-de-açúcar em Latossolo Vermelho-Amarelo Distrófico típico álico, textura média no município de Jaboticabal, SP. Mesmo havendo palhada na superfície dos solos estudados é provável que o tráfego em condições de solo úmido tenha favorecido o aumento da Ds de acordo com Dias e Estanislau (1999).

O VTP nos dois pares de solos (P1, P2, P3 e P4) foram classificados como baixos na profundidade de 0-30 cm segundo critérios propostos por Goedert (2005) que sugerem valores superiores a $0,60 \mathrm{~cm}^{3} \mathrm{~cm}^{-3}$ como adequados para a qualidade agrícola em solos argilosos em clima tropical (Figura 7). Entretanto, Cury et al. (2014) não observaram diferenças na produtividade da cultura da cana-de-açúcar em Latossolo Vermelho Eutroférrico com valores de VTP de 0,63 e $0,58 \mathrm{~cm}^{3} \mathrm{~cm}^{-3}$ a $10-20 \mathrm{~cm}$ nos sistemas de plantio direto e convencional respectivamente.

Em relação ao tamanho de poros dos quatro solos estudados os microporos são predominantes. No par P1 e P2, foi observado mediante descrição morfológica (Tabela 6) o predomínio de plintita no solo 1 abaixo do horizonte concrecionário, esta característica morfológica pode ter contribuído para o maior volume de microporos abaixo do horizonte concrecionário. Provavelmente o maior volume de microporos associado à presença do horizonte concrecionário em profundidade $(150-210 \mathrm{~cm})$ proporcionou oscilação do lençol freático no perfil do solo 1 e pode ter contribuído para a maior retenção de água da precipitação pluviométrica no mês de julho do ano de 2014. Na literatura outras 
características morfológicas dos solos são descritas como importantes para a produtividade da cultura da cana-de-açúcar, como o trabalho de Maule et al. (2001) que não observaram diferenças na produtividade da cana-de-açúcar em solos com descontinuidade no tamanho de poros entre os horizontes de superfície e subsuperfície independente do período de colheita ao longo do ano, devido ao nível do lençol freático se localizar próximo à zona radicular em solos com horizonte B textural. No par de solos 3 e 4 a distribuição de microporos nos solos não é semelhante (Tabela 11). Entretanto, no P3 os microporos têm distribuição heterogênea no perfil do solo comparado ao P4. Segundo Kiehl (1979), o solo com 0,66 $\mathrm{cm}^{3} \mathrm{~cm}^{-3} \mathrm{de}$ microporos torna-se favorável para a produção agrícola, por reter mais água no perfil do solo. $\mathrm{Na}$ camada de 90-210 cm no P3 os microporos são mais predominantes que no P4, provavelmente esta seja uma das causas das maiores produtividades da cana-de-açúcar no P3 no mês de maio dos anos de 2014 e 2015, devido ao maior aproveitamento da precipitação pluviométrica na camada mais adensada do P3 $(90-210 \mathrm{~cm})$ ao final da estação pluviométrica na região de estudo (Tabela 11).

Não foi possível verificar diferenças entre os teores de água disponível (AD) nos dois pares de solos estudados. Mesmo ao avaliar a presença e a ausência de horizonte concrecionário no solo P1 e P2 respectivamente e o caráter químico no par P3 e P4, com maiores teores de cálcio $(\mathrm{Ca})$ no $\mathrm{P} 4$, os volumes de de $\mathrm{AD}$ foram semelhantes (Tabela 12). Campos et al. (2010), compararam a AD em Latossolos Vermelhos Ácricos e VermelhoAmarelos Ácricos petroplínticos do Distrito Federal e concluíram que não houve diferença entre ambas classes de solos. Beutler et al. (2002) identificaram diferenças na capacidade de água disponível entre Latossolos quimicamente diferentes, porém classificados em distintas classes texturais, Latossolo Vermelho Distrófico textura média/argilosa e o Latossolo Vermelho Eutroférrico textura arglosa/argilosa, no município de Jaboticabal, estado de São Paulo. Reatto et al. (2007) não encontraram diferenças na AD de Latossolos distróficos e ácricos do Cerrado Brasileiro. Entretanto, as pesquisas mostram o uso de outros atributos físicos para estimar a AD nos solos com os estudos de Klein e Libardi (2000) que sugerem a Ds como parâmetro favoravél para o armazenamento de água, delimitando o valor de Ds de $1,11 \mathrm{~g} \mathrm{~cm}^{-3}$ para Latossolos muito argilosos do município de Guaíra, SP.

O potencial hídrico foliar na cultura da cana-de-açúcar foi influenciado pela precipitação pluviométrica nos anos de 2014 e 2015. Em 2014 o evento climático atípico na região, precipitação média de $78 \mathrm{~mm}$ no mês de julho proporcionou maior quantidade de água para cultura. O potencial hídrico foliar da cana-de-açúcar no solo P1 - LVwf petroplíntico foi superior comparado ao solo P2 nos anos de 2014 e 2015 (Tabela 13). Os resultados que 
podem auxiliar na comprovação do efeito otimizado do horizonte concrecionário no fornecimento de água para a cultura da cana-de-açúcar são os dados de produtividade da cultura (Tabela 15), superior em 33,14 $\mathrm{Mg} \mathrm{ha}^{-1}$ no solo P1 comparado ao solo P2, no mês de agosto do ano de 2014, mesmo período das avaliações do $\Psi_{\mathrm{w}}$ foliar na cultura. No ano de 2015 apesar do baixo índice pluviométrico e dos valores de $\Psi \mathrm{W}$ foliar da cana-de-açúcar não diferirem estatisticamente entre P1 e P2, a produtividade da cultura foi superior em 5,83 Mg $\mathrm{ha}^{-1}$ no solo P1. O $\Psi_{\mathrm{w}}$ foliar na cultura no solo P1 em 2015, (-1,1 MPa), reduziu-se onze vezes quando comparado ao ano de 2014, (-0,1 MPa). Já no solo P2 a redução foi de duas vezes e meia, -0,6 MPa em 2014 e -1,5 MPa em 2015. Estudos sobre a presença de horizonte concrecionário em subsuperfície e lençol freático mais superficial geralmente demonstram que essa característica morfológica altera o comportamento e desenvolvimento das culturas, como exemplos o trabalho de Mesquita et al. (2007) que justificam a ausência natural de árvores de Araticum em Goiás principalmente pelo acúmulo de água em subsuperfície em solos com horizonte concrecionário, e Papa et al. (2011), que relacionam a ocorrência de espécies vegetais na região do Cerrado do Distrito Federal em função da presença ou ausência do horizonte concrecionário. Pádua Junior et al. (2007) concluíram que a presença de horizonte concrecionário em Cambissolo Háplico Distrófico álico possibilitou melhor ambiente para o crescimento e desenvolvimento da cana-de-açúcar variedade SP813250 no município de Itumbiara, GO devido a maior umidade no perfil do solo.

No mês de agosto dos anos de 2014 e 2015 o $\Psi$ w foliar na cultura nos solos P3 e P4 foram próximos (Tabela 13). A avaliação da produtividade da cana-de-açúcar em ambos os anos no mês de agosto, proporcionaram o mesmo comportamento do potencial hídrico foliar e não se diferenciaram entre si, possivelmente pela mesma condição hídrica da cultura no P3 e P4 (Tabela 15). Mesmo considerados quimicamente distintos (P3 - acriférrico e P4 distroférrico), a análise do complexo sortivo (Tabela 7) demonstrou maior teor de Ca no P4 entre os solos estudados. A produtividade da cultura no mês de outubro de 2015 foi superior para o solo P4 em 9,03 $\mathrm{Mg} \mathrm{ha}^{-1}$ quando comparado ao solo P3. Landell et al. (2003) consideram como critério para estimar a produtividade da cana-de-açúcar ao longo dos corte a soma de bases trocáveis no horizonte $\mathrm{Bw}$ de Latossolos em diferentes locais do Brasil, e classificam a cana-de-açúcar cultivada em Latossolos distróficos mais produtiva que nos Latossolos ácricos.

Portanto, a descrição morfológica do perfil dos solos a caracterização físico-hídrica associada ao $\Psi_{\mathrm{w}}$ foliar da cultura podem explicar a produtividade das soqueiras da cana-de- 
açúcar em anos com alteração climática, provenientes de volume de precipitação pluviométrica em condições atípicas para solos férricos do sul do estado de Goiás.

\section{III.4. CONCLUSÕES}

1. Entre os pares de Latossolos Férricos avaliados, a caracterização morfológica foi fundamental na individualização do horizonte concrecionário em subsuperfície caracterizando o LVwf petroplínico, onde a presença deste horizonte foi considerada o atributo discriminante na variabilidade da produtividade da variedade RB867515 de cana-de-açúcar na região Sul de Goiás em 2014 (meses de maio e agosto) e 2015 (meses de maio e outubro).

2. O horizonte concrecionário no LVwf pode ter proporcionado condição hídrica favorável para o desenvolvimento da cultura em períodos de menor precipitação pluviométrica, proporcionando maiores produtividades da variedade RB867515 de cana-deaçúcar no mês de agosto do ano de 2014 e no mês de outubro de 2015 em relação às produtividades do LVwf típico nestes mesmos períodos.

3. O par de solos Latossolo Vermelho Acriférrico (P3) e o Latossolo Vermelho Distroférrico (P4) provenientes da rocha basáltica na região de Goiatuba são fisicamente semelhantes.

4. O potencial hídrico foliar demonstrou ser uma metodologia eficiente para mensurar o potencial hídrico de base na cana-de-açúcar cultivada em Latossolos com presença de horizonte concrecionário em subsuperfície.

5. O teor de água disponível foi semelhante nos Latossolos Vermelhos Distroférricos típicos e Latossolos Vermelhos Acriférricos típicos e petroplínticos muito argilosos provavelmente não afetou a produtividade da cana-de-açúcar na região Sul do Estado de Goiás. 


\section{III.5. REFERÊNCIAS BIBLIOGRÁFICAS}

ADÁMOLI, J.; MACEDO, J.; AZEVEDO, L. G.; MADEIRA NETTO, J. Caracterização da região dos cerrados. In: GOEDERT, W. (ed.). Solos dos cerrados: tecnologias e estratégias de manejo. São Paulo: Nobel; Brasília, Embrapa Cerrados, Cap. 2, p. 33-74, 1985.

ALBUQUERQUE, J.A.; REINERT, D.J. Densidade radicular do milho considerando os atributos de um solo com horizonte B textural. Revista Brasileira de Ciência do Solo, v. 25, p. 539-549, 2001.

ALLEONI, L.R.F.; CAMARGO, O.A. Atributos físicos de Latossolos ácricos do norte paulista. Scientia agricola, v. 51, p. 321-326, 1994.

ARAÚJO, R.; GOEDERT, W. J.; LACERDA; M. P. C. Qualidade de um solo sob diferentes usos e sob Cerrado nativo. Revista Brasileira de Ciência do Solo, v. 31, p. 1099-1108, 2007.

BEUTLER, A.N.; CENTURION, J.F.; SOUZA, Z.M.; ANDRIOLI, I.; ROQUE, C.G. Retenção de água em dois tipos de Latossolos sob diferentes usos. Revista Brasileira de Ciência do Solo, v. 26, p. 829-834, 2002.

BIONDI, C.M.; NASCIMENTO, C.W.A.; FABRICIO NETA, A.B.; RIBEIRO, M.R. Teores de $\mathrm{Fe}, \mathrm{Mn}, \mathrm{Zn}, \mathrm{Cu}$, Ni e Co em solos de referência de Pernambuco. Revista Brasileira de Ciência do Solo, v. 35, p. 1057-1066, 2011.

BOUMA, J. Influence of soil macroporosity on environmental quality. Advances in Agronomy, v. 46, p. 2-37, 1991.

CAMARGO, M.S.; KORNDÖRFER, G.H.; PEREIRA, H.S. Solubilidade do silício em solos: influência do calcário e ácido silícico aplicados. Bragantia, v. 66, p. 637-647, 2007.

CAMILOTTI, F.; ANDRIOLI, I.; DIAS, F.L.F.; CASAGRANDE, A.A.; SILVA, A.R.; MUTTON, M.A.; CENTURION, J.F. Efeito prolongado de sistemas de preparo do solo com e sem cultivo de soqueira de cana crua em algumas propriedades físicas do solo. Engenharia Agrícola, v. 25, p. 189-198, 2005.

CAMPOS, P.M.; LACERDA, M.P.C.; SILVA, C.L.; SÁ, M.A.C; SOUSA, D.M.G. Drenagem interna como fator de diferenciação de Latossolos do Distrito Federal. Pesquisa Agropecuária Brasileira, v. 45, p. 306-314, 2010.

CEDDIA, M.B.; ANJOS, L.H.C.; LIMA, E.; RAVELLI NETO, A.; SILVA, L.A. Sistemas de colheita da cana-de-açúcar e alterações nas propriedades físicas de um solo Podzólico Amarelo no estado do Espírito Santo. Pesquisa Agropecuária Brasileira, v. 34, p. 14671473, 1999.

CONAB - COMPANHIA NACIONAL DE ABASTECIMENTO. Acompanhamento da safra brasileira de cana-de-açúcar, safra 2016/2017. Primeiro levantamento. 2016. Disponível em: <http://www.conab.gov.br/conteudos.php?a=1253\&t=2>. 
CORREIA, J.R.; REATTO, A.; SPERA, S.T. Solos e suas relações com o uso e manejo. In: SOUSA, D.M.G.de; LOBATO, E. Cerrado Correção do solo e adubação. Empresa Brasileira de Pesquisa Agropecuária. Embrapa Cerrados. Planaltina, 2002, p.43.

COSTA, S.A.D.; KER, J.C.; SIMÕES, D.F.F.; FONTES, M.P.F.; FABRIS, J.D.; ANDRADE, F.V. Pedogênese e classificação de Latossolos desenvolvidos de itabiritos no Quadrilátero Ferrífero, MG. Revista Brasileira de Ciência do Solo, v. 38, p. 359-371, 2014.

CUNHA, T.J.F.; BLANCANEAUX, P.; CALDERANO, FILHO, B.; CARMO, C.A.F.S.; GARCIA, N.C.P.; LIMA.E.M.B. Influência da diferenciação pedológica no desenvolvimento da seringueira no município de Oratórios, MG. Pesquisa Agropecuária Brasileira, v. 35, p. 145-155, 2000.

CURY, N.; FRANZMEIER, D.P. Toposequence of Oxisols from the Central Plateau of Brazil. Soil Science Society of America Journal. v. 48, p. 341-346, 1984.

CURY, T.N.; MARIA, I.C.; BOLONHEZI, D. Biomassa radicular da cultura de cana-deaçúcar em sistema convencional e plantio direto com e sem calcário. Revista Brasileira de Ciência do Solo, v. 38, p. 1929-1938, 2014.

DEMATTÊ, J.L.I.; DEMATTÊ, J.A.M. Ambientes de Produção como estratégia de manejo na cana-de-açúcar. Informações Agronômicas, nº 127, Piracicaba, 2009.

DEXTER, A.R. Soil physical quality part I: theory, effects of soil texture, density, and organic matter, and effects on root growth. Geoderma, Amsterdam, v. 120, p. 201-2014, 2004.

DIAS, F.L.F.; MAZZA, J.A.; MATSUOKA, S.; PERECIN, D.; MAULE, R.F. Produtividade da cana-de-açúcar em relação a clima e solos da região noroeste do estado de São Paulo. Revista Brasileira de Ciência do Solo, v. 23, p. 627-634, 1999.

DIAS JUNIOR, M.S.; ESTANISLAU, W.T. Grau de compactação e retenção de água de Latossolos submetidos a diferentes sistemas de manejo. Revista Brasileira de Ciência do Solo, v. 23, p. 45-51, 1999.

DOURADO-NETO, D.; NIELSEN, D.R.; HOPMANS, J.W.; REICHARDT, K.; BACCHI, O.O.S. Software to model soil water retention curves (SWRC, version 2.00). Scientia Agricola, vol. 57, p. 191-192, 2000.

EMPRESA BRASILEIRA DE PESQUISA AGROPECUÁRIA (EMBRAPA). Manual de métodos de análise de solo. 2.ed. rev. atual. Rio de Janeiro: Embrapa-CNPS, 1997. 212p.

EMPRESA BRASILEIRA DE PESQUISA E AGROPECUÁRIA (EMBRAPA). Sistema Brasileiro de Classificação de Solos. $3^{\text {a }}$ edição, Brasília, 2013. 353p.

ERNESTO, M. Estado da Arte do Paleomagnetismo do Cretáceo da América do Sul. In: SIMPÓSIO SOBRE O CRETÁCEO DO BRASIL, 5, 1999, Serra Negra. Resumos Expandidos... 1999, p. 157-160. 
FERREIRA, I.C.de.M.; COELHO, R.M.; TORRES, R.B.; BERNACCI, L.C. Solos e vegetação nativa renascente no município de Campinas. Pesquisa Agropecuária Brasileira, v. 42, p. 1319-1327, 2007.

FREITAS JÚNIOR, E.; SILVA, E.M. da. Uso de centrífuga para determinação da curva de ret enção de água do solo, em uma única operação. Pesquisa Agropecuária Brasileira, v. 19, p. 1423-1428, 1984.

GALRÃO, E.Z. Micronutrientes. In: SOUSA, D.M.G.de; LOBATO, E. Cerrado Correção do solo e adubação. Empresa Brasileira de Pesquisa Agropecuária. Embrapa Cerrados. Planaltina, 2002, p.185-226.

GAVA, G.J.C.; SILVA, M.A.; SILVA, R.C.; JERONIMO, E.M.; CRUZ, J.C.S.; KÖLLN, O.T. Produtividade de três cultivares de cana-de-açúcar sob manejos de sequeiro e irrigado por gotejamento. Revista Brasileira de Engenharia Agrícola e Ambiental. v. 15, p. 250 $255,2011$.

GOEDERT, W. J. Qualidade do solo em sistemas de produção agrícola. In: CONGRESSO BRASILEIRO DE CIÊNCIA DO SOLO, 30. 2005, Recife. Anais... Recife: SBCS, 2005. 1 CD-ROM.

GROHMANN, F. Distribuição e tamanho de poros em três tipos de solos do estado de São Paulo. Boletim técnico do Instituto Agronômico do Estado de São Paulo. Bragantia, v. 19, p. 319-328, 1960.

JOAQUIM, A.C; DONZELLI, J.L; QUADROS, A.C; SARTO, L.F. Potencial de produção de cana-de-açúcar. In: Seminário de Tecnologia Agronômica. Centro de Tecnologia Coopersucar. Piracicaba. 1997, Anais... Piracicaba, 1997, p. 68-76.

KER, J.C. Latossolos do Brasil: Uma revisão. Geonomos. v. 5, p. 17-40, 1997.

KIEHL, E.J. Manual de edafologia: relação solo-planta. São Paulo: Nobel, 262p., 1979.

KLEIN, V.A.; LIBARDI, P.L. Faixa de umidade menos limitante ao crescimento vegetal e sua relação com a densidade do solo ao longo de um perfil de um Latossolo Roxo. Revista Ciência Rural, v. 30, p. 959-964, 2000.

KOOREVAAR, P.; MENELIK, G.; DIRKSEN, C. Elements of soil physics. Developments in Soil Science. Elsevier, Amsterdam, v. 13, 1983.

LACERDA, M.P.C.; ANDRADE, H.; QUÉMÉNEUR, J.J.G. Pedogeoquímica em perfis de alteração na região de Lavras (MG). II - Elementos menores e elementos das terras raras. Revista Brasileira de Ciência do Solo, v. 26, p. 87-102, 2002.

LANDELL, M.G.A.; PRADO, H.; VASCONCELOS, A.C.M.; PERECIN, D.; ROSSETTO, R.; BIDÓIA, M.A.P.; SILVA, M.A.; XAVIER, M.A. Oxisol subsurface chemical attributes related to sugarcane productivity. Scientia Agricola, v. 60, p. 741-745, 2003. 
LIMA, C.G.R.; CARVALHO, M.P.; MELLO, L.M.M.; LIMA, R.C. Correlação linear e espacial entre a produtividade de forragem, a porosidade total e a densidade do solo de Pereira Barreto (SP). Revista Brasileira de Ciência do Solo, v. 31, p. 1233-1244, 2007.

LIMA, V.M.P.; OLIVEIRA, G.C.; SEVERIANO, E.C.; OLIVEIRA, L.F.C. Intervalo hídrico ótimo e porosidade de solos cultivados em área de proteção ambiental do sul de Minas Gerais. Revista Brasileira de Ciência do Solo, vol. 33, p. 1087-1095, 2009.

LOPES, A. S. Solos sob cerrado: características, propriedades, manejo. 2 ed. Piracicaba: POTAFOS, 162 p., 1984.

MARIN, F.; NASSIF, D.S.P. Mudanças climáticas e a cana-de-açúcar no Brasil: Fisiologia, conjuntura e cenário futuro. Revista Brasileira de Engenharia Agrícola e Ambiental, v. 17, p. 232-239, 2013.

MAULE, R. F; MAZZA, J. A.; MARTHA JR, G. B. Produtividade agrícola de cultivares de cana-de-açúcar em diferentes solos e épocas de colheita. Scientia Agricola, v. 58, p. 295-301, 2001.

MACHADO, F.B.; NARDY, A.J.R, ROCHA JÚNIOR, E.R.V.; MARQUES, L.S.; OLIVEIRA, M.A.F. Geologia e litogeoquímica da formação Serra Geral nos estados de Mato Grosso e Mato Grosso do Sul. Revista Geociências, v. 28, p. 523-540, 2009.

MACHADO, R.S.; RIBEIRO, R.V.; MARCHIORI, P.E.R.; MACHADO, D.F.S.P.; MACHADO, E.C.; LANDELL, M.G.A. Respostas biométricas e fisiológicas ao deficit hídrico em cana-de-açúcar em diferentes fases fenológicas. Pesquisa Agropecuária Brasileira, v.44, p. 1575-1582, 2009.

MINISTÉRIO DA AGRICULTURA. Levantamento de recomendação dos solos do estado de São Paulo. Boletim do Serviço Nacional de Pesquisas Agronômicas. 1960, 634p.

MESQUITA, M.A.M.; NAVES, R.V.; SOUZA, E.R.B.; BERNARDES, T.G.; SILVA, L.B. Caracterização de ambientes com alta ocorrência natural de Araticum (Annona crassiflora Mart.) no estado de Goiás. Revista Brasileira de Fruticultura, v. 29, p. 15-19, 2007.

MÜLLER, R.D.; ROYER, J.; LAWVER, L.A. Revised plate motions relative to the hotspots from combined Atlantic and Indian Ocean hotspots tracks. Geology, v. 191, p. 27-53, 1993.

OLIVEIRA, F.C.; CASTRO, M.L.L.; RODRIGUES, C.; BORGES, J.D. Isotermas de sorção de metais pesados em solos do cerrado de Goiás. Revista Brasileira de Engenharia Agrícola e Ambiental. v. 14, 776-782, 2010.

OLIVEIRA, L.A.; CAMPOS, J.E.G. Condições de circulação do Sistema Aquífero Guarani no estado de Goiás. Revista Brasileira de Geociências, v. 42, p. 186-195, 2012.

PÁDUA JUNIOR, A.L.; PRADO, H.; MACHADO, B.A.; PETRI, H.D. Influência do caráter plíntico no desenvolvimento da cana-de-açúcar. In: XXXI Congresso Brasileiro de Ciência do Solo, 2007, Gramado, Anais... Gramado, 2007. 
PAPA, R.A.; LACERDA, M.P.C.; CAMPOS, P.M.; GOEDERT, W.J.; RAMOS, M.L.G.; KATO, E. Qualidade de Latossolos Vermelhos e Vermelho-Amarelos sob vegetação nativa de Cerrado. Pesquisa Agropecuária Tropical, v. 41, p. 564-571, 2011.

PAULINO, A.F.; MEDINA, C.C.; AZEVEDO, M.C.B.; SILVEIRA, K.R.P.; TREVISAN, A.A.; MURATA, I.M. Escarificação de um Latossolo Vermelho na pós-colheita de soqueira de cana-de-açúcar. Revista Brasileira de Ciência do Solo, v. 28, p. 911-917, 2004.

PINCELLI, R.P. Tolerância à deficiência hídrica em cultivares de cana-de-açúcar avaliada por meio de variáveis morfofisiológicas. Botucatu: Universidade Estadual de São Paulo, 2010. 65p. Dissertação Mestrado.

PRADO, H. do. Levantamento fotopedológico semidetalhado de uma área da região nordeste do Estado de São Paulo. Piracicaba: Escola Superior de Agricultura Luiz de Queiroz da Universidade de São Paulo - ESALQ-USP, 1993. 159p. Tese de Doutorado.

RAIJ, B. VAN. Fertilidade do Solo e Manejo de Nutrientes. International Plant Nutrition. Piracicaba, 2011, 420p.

REATTO, A.; BRUAND, A.; SILVA, E.M.; MARTINS, E.S.; BROSSARD, M. Hydraulic properties of the diagnostic horizon of Latosols of a regional toposequence across the Brazilian Central Plateau. Geoderma, v. 139, p. 50-59, 2007.

RENNE, P.R.; DECKART, K.; ERNESTO, M.; FÉRAUD, G.; PICCIRILLO, E.M. Age of the Ponta Grossa dike swarm (Brazil), and implications to Paraná flood volcanism. Earth and Planetary Science Letters, v. 144, p. 199-211, 1996.

RESENDE, M.; CURI, N.; REZENDE, S. B.; CORRÊA, G. F. Pedologia: base para distinção de ambientes. Lavras, 5a ed. UFLA, 322 p., 2007.

RIBEIRO, M.R.; HALSTEATED, E.H.; JONG, E. DE Rendimento da cana-de-açúcar e características das terras da microrregião da mata norte de Pernambuco. Revista Brasileira de Ciência do Solo, v. 8, p. 209-213, 1984.

RIDESA Rede Interuniversitária para o Desenvolvimento do Setor Sucroalcooleiro. Catálogo nacional de variedades "RB" de cana-de-acúcar. Curitiba, 2010. 136 p.

RODOLFO JUNIOR, F. Caracterização de variedades de cana-soca sob diferentes regimes hídricos no Cerrado. Brasília: Universidade de Brasília, 2015. 120p. Tese Doutorado.

SANTOS, F.C.; NOVAIS, R.F.; NEVES, J.C.L.; FOLONI, J.M.; ALBUQUERQUE FILHO, M.R.; KER, J.C. Produtividade e aspectos nutricionais de plantas de soja cultivadas em solos de cerrado com diferentes texturas. Revista Brasileira de Ciência do Solo, v.32, p. 20152025, 2008.

SANTOS, D.S.; LEMOS, R.C.; SANTOS, H.G.; KER, J.C.; ANJOS, L.H.C.; SHIMIZU, S.H. Manual de descrição e coleta de solo no campo. 6. ed. Revisada e ampliada, Viçosa, MG, Sociedade Brasileira de Ciência do Solo, 2013. 100p. 
SCARPARI, M.S.; BEAUCLAIR, E.G.F. Anatomia e Botânica. In: DINARDO-MIRANDA, L.L.; VASCONCELOS, A.C.M.; LANDELL, M.G.A. Cana-de-Açúcar, Instituto Agronômico. Campinas. 2010, p. 47-56.

SCHOLANDER, P. F. et al. Sap pressure in vascular plants. Science, v. 148, p. 339-346, 1965.

SEVERIANO, E.C.; OLIVEIRA, G.C.; DIAS JÚNIOR, M.S.; CASTRO, M.B.; OLIVEIRA, L.F.C.; COSTA, K.A.P. Compactação de solos cultivados com cana-de-açúcar: I -modelagem e quantificação da compactação adicional após as operações de colheita. Engenharia Agrícola, v. 30, p. 404-413, 2010.

SILVA, A.P.; LIBARDI, P.L.; CAMARGO, O. A. Influência da compactação nas propriedade físicas de dois Latossolos. Revista Brasileira de Ciência do Solo, v. 10, p. 9195, 1986.

SILVA, M DE A., JERONIMO, E.M.; LÚCIO, A.D. Perfilhamento e produtividade de canade-açúcar com diferentes alturas de corte e épocas de colheita. Pesquisa Agropecuária Brasileira, v. 43, p. 979-986, 2008.

SILVA, M.A.; ARANTES, M.T.; RHEIN, A.F.L.; GAVA, G.J.C.; KOLLN, O.T. Potencial produtivo da cana-de-açúcar sob irrigação por gotejamento em função de variedades e ciclos.

Revista Brasileira de Engenharia Agrícola e Ambiental, v.18, p. 241-249, 2014.

SOARES, J.L.N.; ESPINDOLA, C.R.; FOLONI, L.L. Alteração física e morfológica em solos cultivados com citros e cana-de-açúcar, sob sistema tradicional de manejo. Ciência Rural, v. 35, p. 353-359, 2005.

SOUSA, C.C.M.; PEDROSA, E.M.R.; ROLIM, M.M.; PEREIRA FILHO, J.V.; SOUZA, M.A.L.M. Influência da densidade do solo infestado por nematoide no desenvolvimento inicial de cana-de-açúcar. Revista Brasileira de Engenharia Agrícola e Ambiental, v.18, p. 475-479, 2014.

SOUZA, Z.M.; PRADO, R.M.; PAIXÃO, A.C.S.; CESARIN, L.G. Sistemas de colheita e manejo da palhada de cana-de-açúcar. Pesquisa Agropecuária Brasileira, v. 40, p. 271-278, 2005.

SOUZA, Z.M.; MARQUES JÚNIOR, J.; COOPER, M.; PEREIRA, G.T. Micromorfologia do solo e sua relação com atributos físicos e hídricos. Pesquisa Agropecuária Brasileira, v.41, p. 487-492, 2006.

TORRES, L.C.; BARROS, K.R.M.; LIMA, H.V. Alterações na qualidade física de um Latossolo Amarelo sob pastagem. Acta Amazônica. v. 44, p. 419 - 426, 2014.

THIEDE, D.S.; VASCONCELOS, P.M. Paraná flood basalts: Rapid extrusion hypothesis support by new 49Ar/39Ar results. In: CONGRESSO BRASILEIRO DE GEOLOGIA, 44, 2008, Curitiba. Resumos... Paraná: Sociedade Brasileira de Geologia, 2008, 563p. 
UEHARA, G. Acric properties and their significance to soil classification. In: INTERNATIONAL SOIL CLASSIFICATION WORKSHOP, 8, Rio de Janeiro, 1986. Proceedings. Rio de Janeiro: EMBRAPA/ SNLCS, 1988. p.19-22.

VAN GENUCHTEN, M.T. A closed form equation for predicting the hydraulic conductivity of unsaturated soils. Soil Science Society of America Journal, v. 44, p. 892-898, 1980.

VAN WAMBEKE, Management properties of Ferrasols. FAO, Roma, Soil Buletin, v.23, p.129, 1974.

VERMA, R.S. Ratoon decline in sugar cane. Cooperative Sugar, v.26, p. 349-351, 1995.

VIEIRA, G.H.S.; MANTOVANI, E.C.; SEDIYAMA, G.C.; DELAZARI, F.T. Indicadores morfo-fisiológicos do estresse hídrico para a cultura da cana-de-açúcar em função de lâminas de irrigação. Bioscience Journal, v. 30, p. 65-75, 2014.

VOMOCIL, J.A.; FLOCKER, W.J. Effects of soil compaction on storage and movement of soil, air and water.American Society Agricultural Engineering, v.4, p.242-246, 1966.

ZANÃO JÚNIOR, L.A.; LANA, R.M.Q.; GUIMARÃES, E.C. Variabilidade espacial do pH, teores de matéria orgânica e micronutrientes em profundidades de amostragem num Latossolo Vermelho sob semeadura direta. Ciência Rural, v. 37, p.1000-1007, 2007. 


\section{III.6 - ANEXOS}

Foi ajustada à curva de retenção de água a equação de van Genuchten (1980), adotando-se a restrição de Mualem (1986) - equação 1.

$$
\theta=\theta r+\frac{(\theta s-\theta r)}{\left[1+(\alpha \times \Psi)^{n}\right]^{\left[1-\frac{1}{n}\right]}}
$$

Onde: $\theta\left(\mathrm{cm}^{3} \mathrm{~cm}^{-3}\right)$ é o teor de água volumétrico; $\theta \mathrm{r}$ e $\theta \mathrm{s}\left(\mathrm{cm}^{3} \mathrm{~cm}^{-3}\right)$ são os teores de água residual e saturado, respectivamente; $\Psi(\mathrm{hPa})$ é a tensão de água no solo (módulo do potencial mátrico), expressa em kPa e $\alpha$ e n são parâmetros de ajuste do modelo. 
Tabela 1A. Teores de água gravimétricos obtidos em diferentes tensões mátricas e parâmetros de ajuste da equação de van Genuchten para o ponto 1 - Latossolo Vermelho Acriférrico petroplíntico - LVwf petroplíntico.

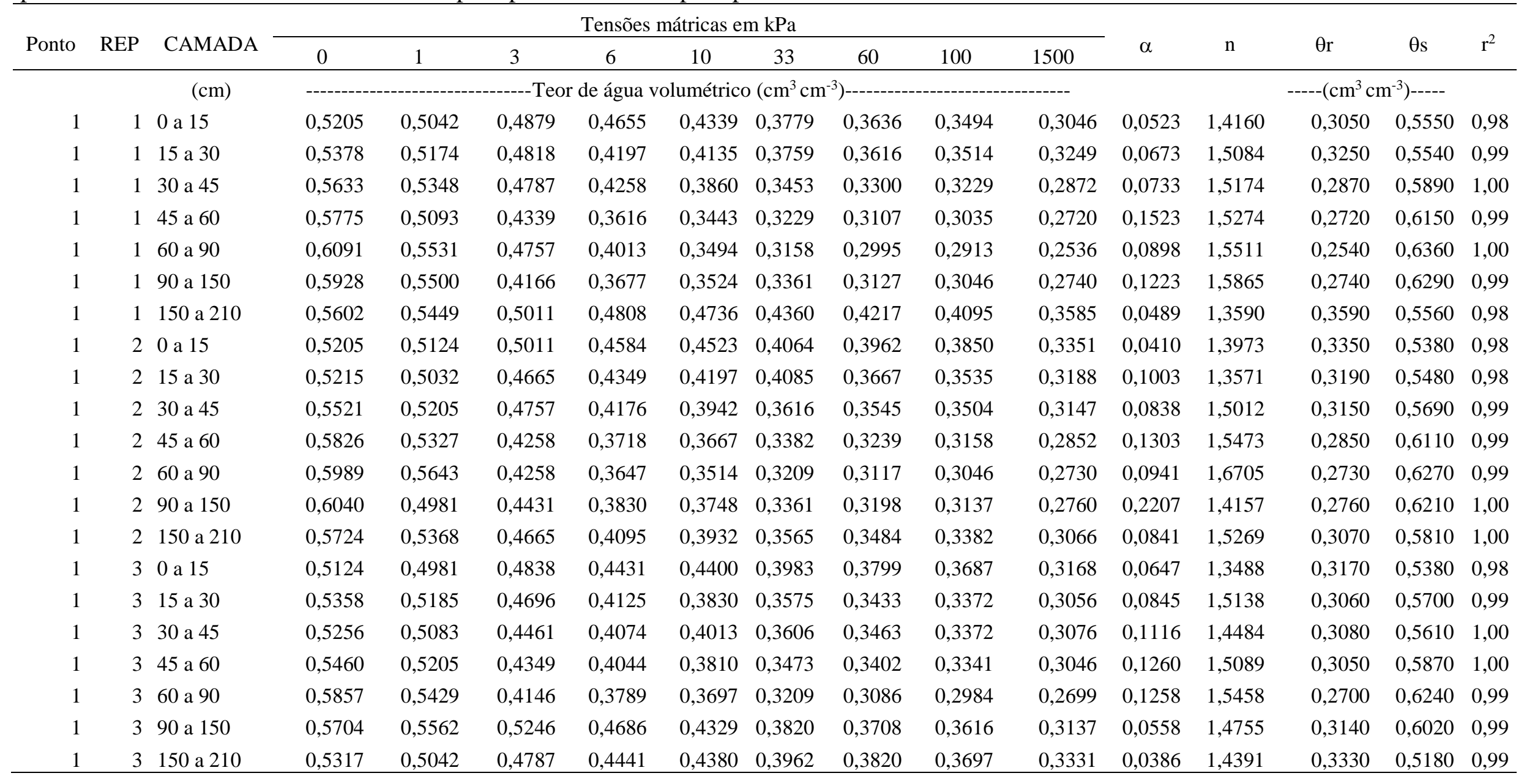


Tabela 2A. Teores de água gravimétricos obtidos em diferentes tensões mátricas e parâmetros de ajuste da equação de van Genuchten para o ponto 2 - Latossolo Vermelho Acriférrico típico - LVwf

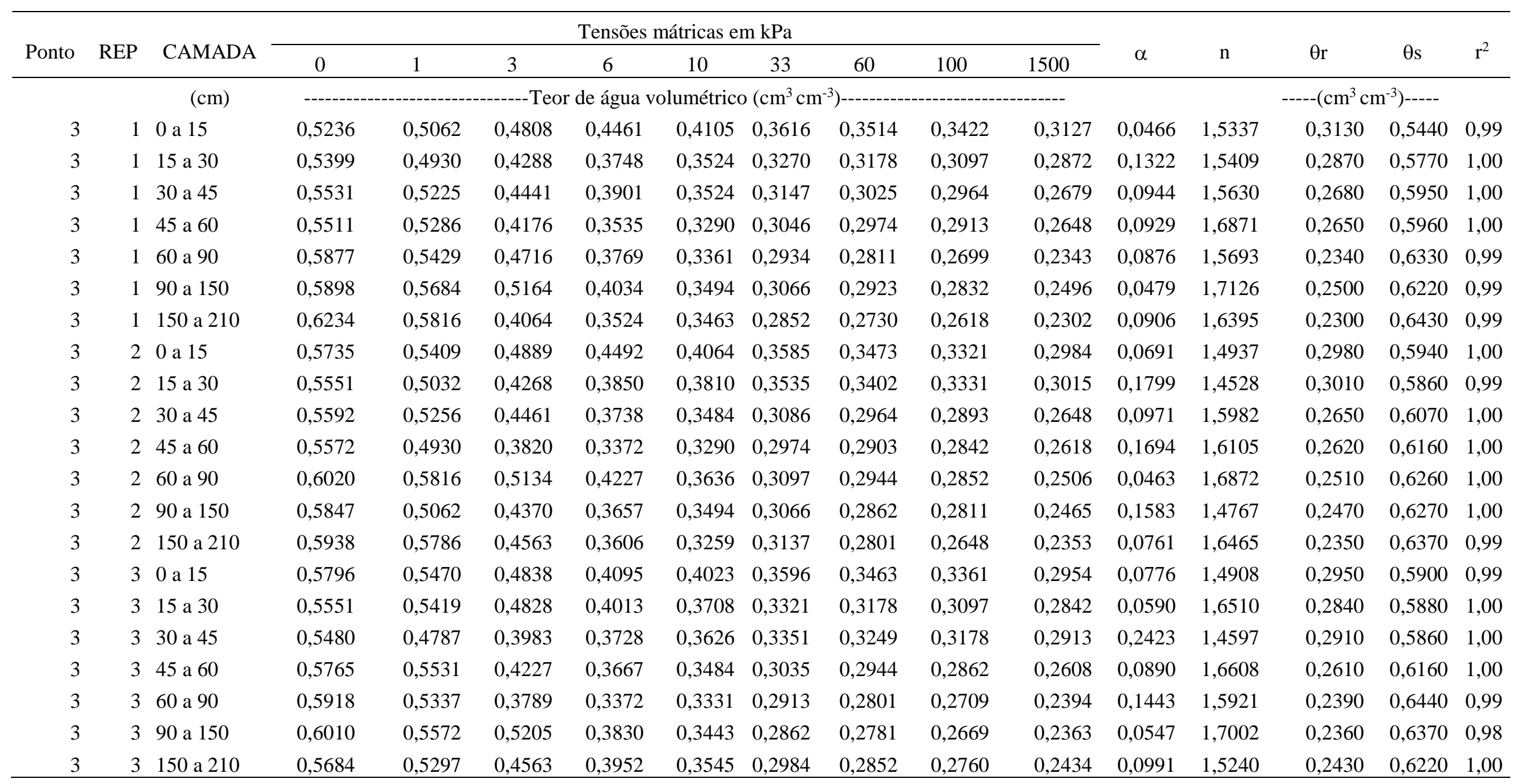


Tabela 3A. Teores de água gravimétricos obtidos em diferentes tensões mátricas e parâmetros de ajuste da equação de van Genuchten para o ponto 3 - Latossolo Vermelho Acriférrico típico - LVwf

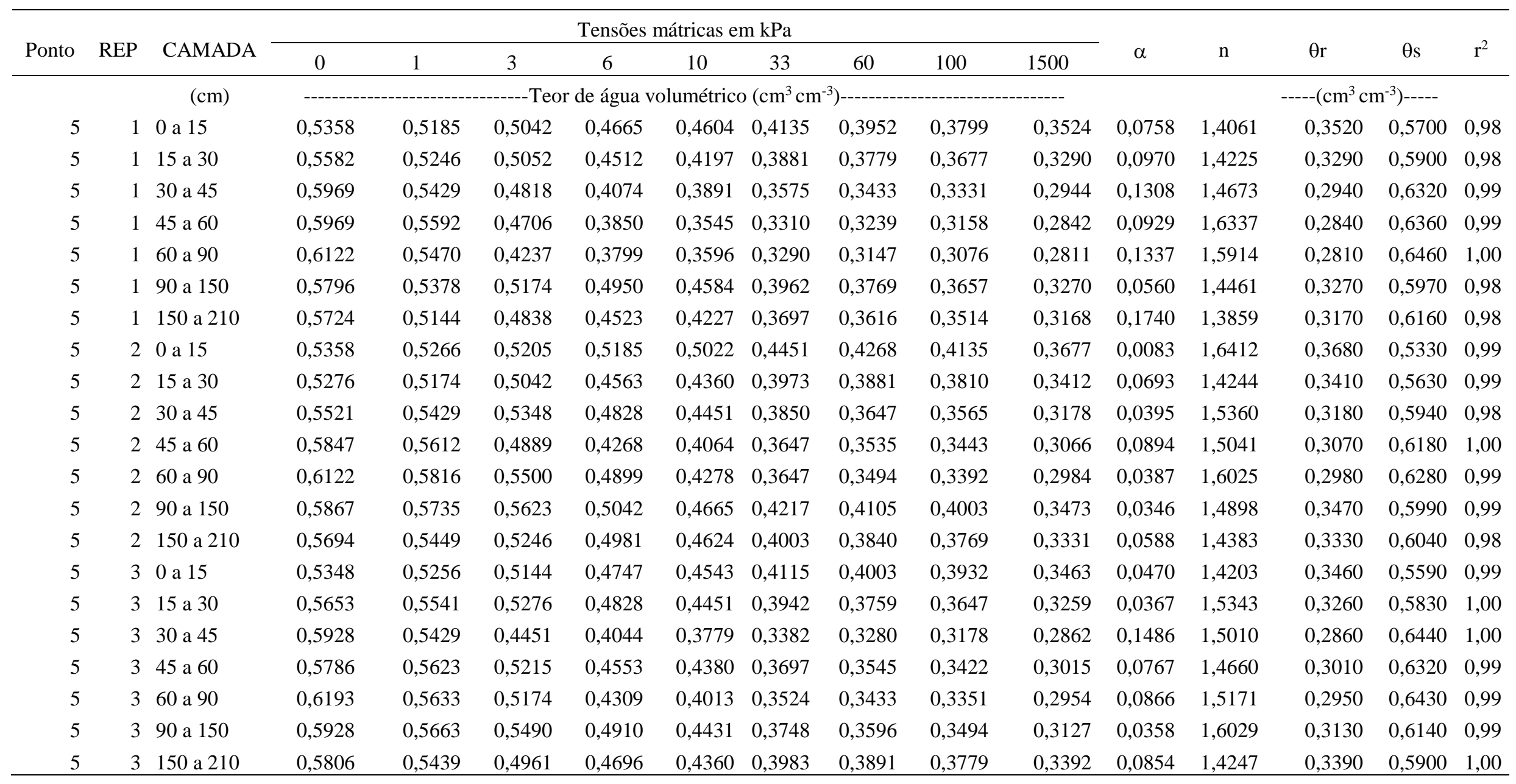


Tabela 4A. Teores de água gravimétricos obtidos em diferentes tensões mátricas e parâmetros de ajuste da equação de van Genuchten para o ponto 4 - Latossolo Vermelho Distroférrico típico - LVdf

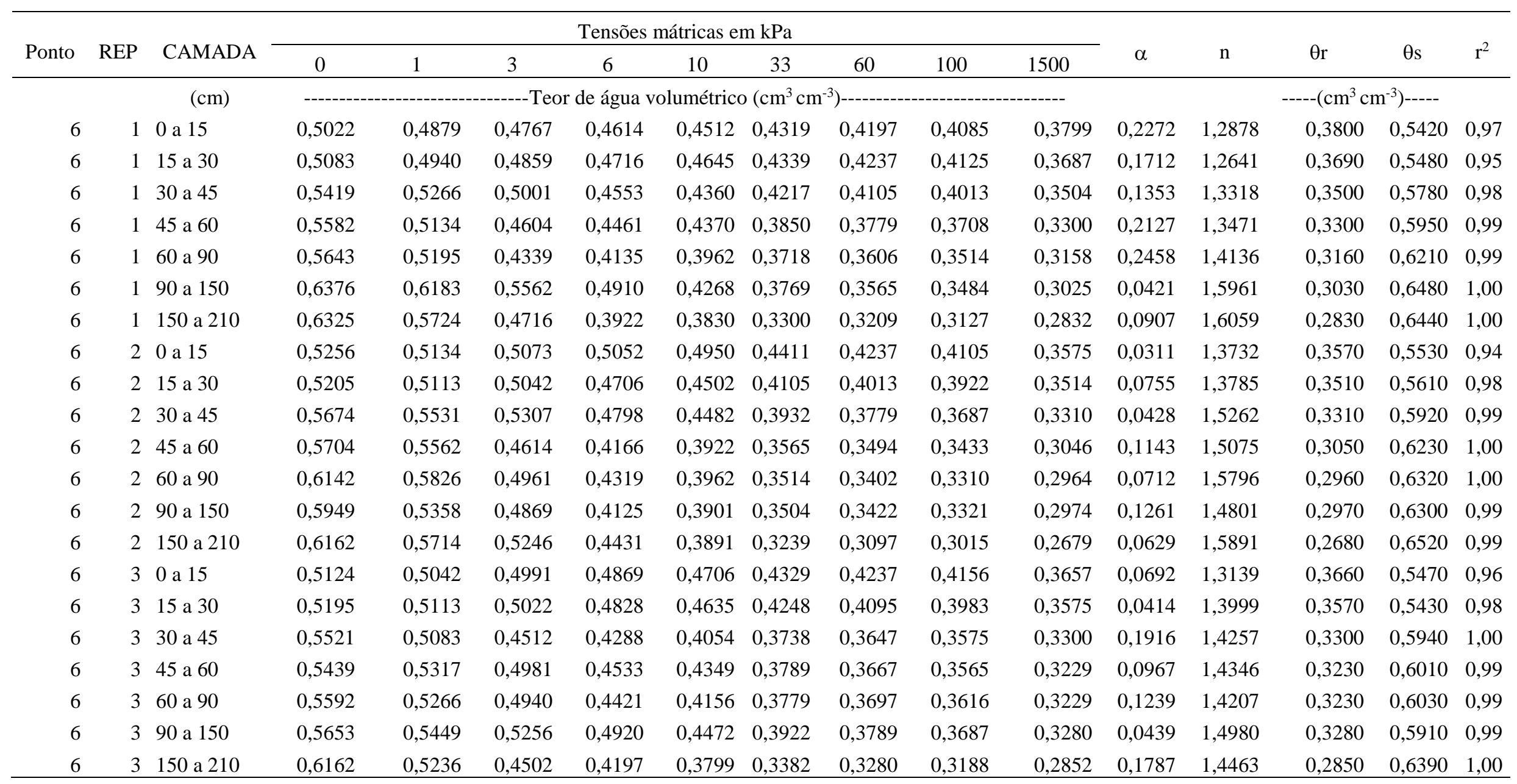

